
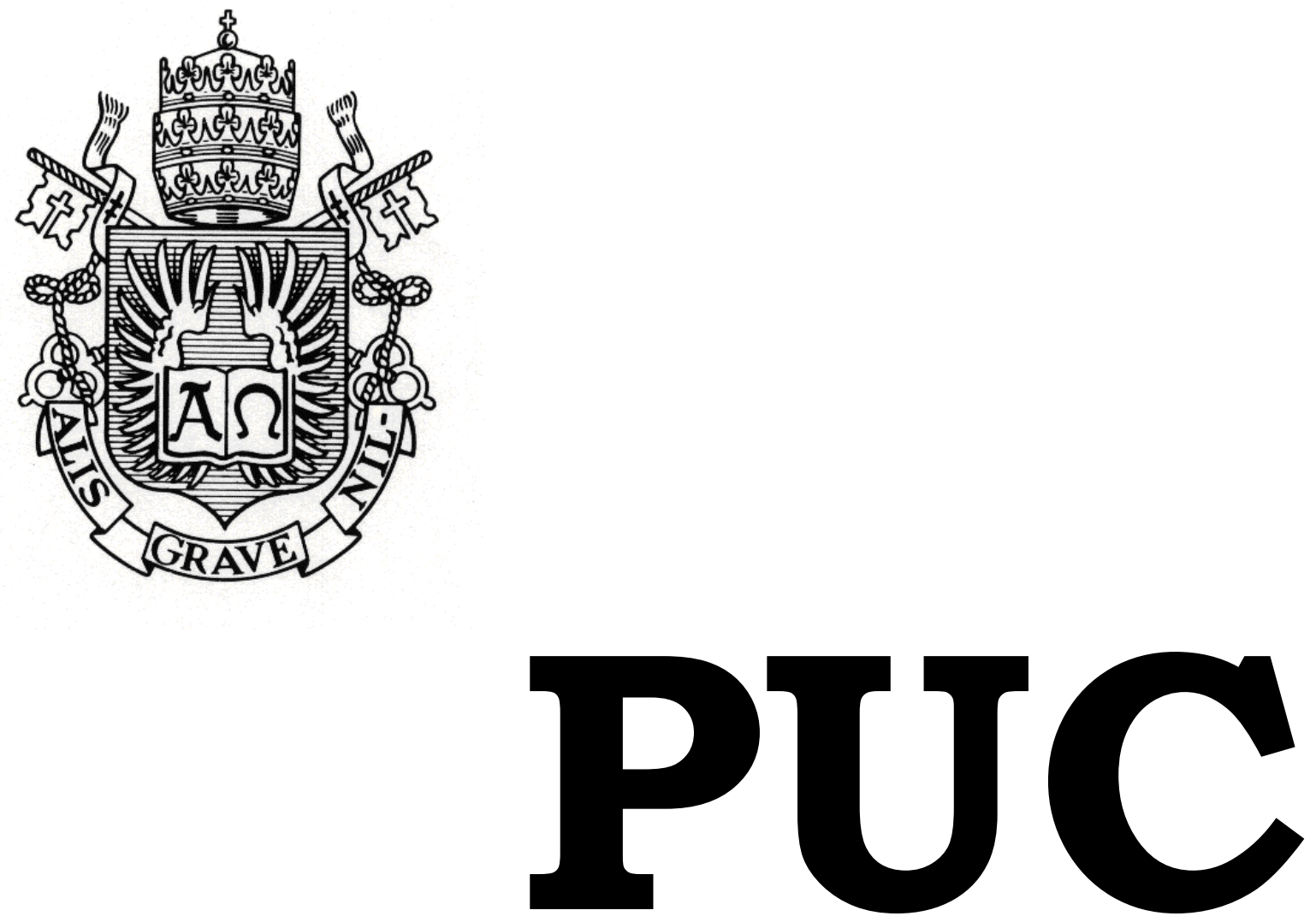

DEPARTAMENTO DE DIREITO

A presunção de inocência nos crimes econômicos

por

Raissa Nunes de Barros

ORIENTADORA: Victoria-Amália Sulocki

2018.2

PONTIFÍCIA UNIVERSIDADE CATÓLICA DO RIO DE JANEIRO

RUA MARQUÊS DE SÃO VICENTE, 225 - CEP 22453-900

RIO DE JANEIRO - BRASIL 


\title{
A PRESUNÇÃO DE INOCÊNCIA NOS CRIMES ECONÔMICOS
}

\author{
por
}

RAISSA NUNES DE BARROS

Monografia apresentada ao Departamento de Direito da Pontificia Universidade Católica do Rio de Janeiro (PUCRio) para a obtenção do Título de Bacharela em Direito.

Orientadora: VictoriaAmália de Sulocki 


\section{Agradecimentos}

À minha mãe Márcia, pelo amor e apoio incondicional que me lançaram ao mundo e me proporcionaram a certeza de uma base para a qual eu sempre possa regressar, e à Bela, pelo carinho e ensinamentos dispensados ao longo de tantos anos.

Aos primos "cariocas", Catarina e Gabriel, pelo convívio, atenção e conselhos. E aos demais, Mateus, Camila, Vanessa, Daniel, Juliana, Samuel, Débora e Eduardo, bem como aos tios e tias Ana Zélia, Verônica, Carlos Luís, Maria do Carmo, Mônica, Gerinaldo e Elisabeth, por terem contribuído, cada um em sua maneira, para o meu crescimento.

Aos amigos de Santo Agostinho, Renata, Macena, Raphael, Lucas, Priscila, Yasmin, Duque, por terem sobrevivido ao experimento social que é aquela saudosa instituição de ensino, e terem permanecido como amizades verdadeiras, apesar da distância.

Às amigas que ingressaram comigo na PUC, Anabella, Isabela, Rafaela, Érika, Julia, Vitória e Victoria, pelas discussões e trocas que me inspiram a questionar o que se aprende, e lutar pelo que se acredita. É um grande orgulho ingressar no meio jurídico ao lado dessas profissionais.

Às amigas de MPF, Bruna, Ingrid e Maria Paula, bem como às de jogos jurídicos, Thaís e Bruna, pelo carinho e por todas as experiências que compartilhamos.

À Aléxia, pela amizade instantânea e verdadeira, e pelas conversas e aventuras que em muito definem quem eu me tornei. E ao Amir e André, pela confiança e apoio nessas jornadas. 
Ao Lukas, pelo carinho, amor e atenção que me foram dedicados nesse momento crítico que é a conclusão da graduação.

Superadas as questões preliminares, adentra-se no mérito da minha formação profissional-acadêmica.

À minha admirável orientadora, Victória-Amália Sulocki, que desde sua primeira aula de Processo Penal, em fevereiro de 2016, me mostrou que o Direito é o nosso instrumento de luta na defesa dos direitos fundamentais e garantias individuais. Suas excelentes aulas e sua cuidadosa orientação, tanto no PIBIC quanto para este trabalho, foram essenciais para minha formação humanizada.

Aos professores André Perecmanis e Sérgio Chastinet, pela honra de terem compartilhado comigo tanto conhecimento e paixão pelo direito penal, e por terem sido decisivos nessa minha opção.

Aos professores Caitlin Mulholland, Regina Coeli, Breno Melaragno, Manoel Peixinho, Adriano Pilatti, Ivan Garcia, João Berthier, Thiago Varela, Samantha Pelajo, Carlos Frederico, Flávia Limmer e Alessandro Molon, por toda a instrução sobre os demais campos do direito, essenciais à minha formação. E ao professor Pedro Marcos Barbosa, por toda a sabedoria compartilhada.

Ao grupo de pesquisa PIBIC Inocência: estudos sobre a presunção de inocência, que desde sua criação me incentivou o senso crítico, e proporcionou o contato com o tema ora abordado em monografia.

À Daniele Nogueira, por toda a paciência e lições humanizadas sobre os direitos dos hipossuficientes no âmbito civil, durante meu estágio na Defensoria Pública. 
Ao Ricardo Nunes e ao Ciro de Albuquerque, pelos relevantes ensinamentos compartilhados sobre a propriedade intelectual e o então novo processo civil.

À Cíntia Melo Damasceno, pelas discussões, trocas e orientações sobre o direito penal e processual penal, bem como sobre a atuação democrática do Ministério Público Federal. É um exemplo de correição profissional que muito me incentivou a escolher essa honrosa carreira.

À Carla Amigo, pelo carinho, e por enriquecer os debates e incentivar minha atuação junto ao órgão ministerial, na defesa da coletividade.

À Arianne Câmara Nery, pelo exemplo de excelência profissional, que me desafiou a desenvolver minhas próprias habilidades advocatícias, e por sempre ter me tratado como igual, uma verdadeira dupla. Se não fiquei, acredite: foi por pouco.

À Júlia Sandroni, Daniel Ribeiro, Felipe Jobim, Thaísa Souza e Iasmim Passos, por terem me proporcionado um excelente ambiente de aprendizado, e pelo exemplo de correição na advocacia. 


\title{
Resumo
}

Neste trabalho, busca-se analisar os valores inerentes à presunção de inocência, por meio de seu histórico, suas dimensões e sua recepção no ordenamento jurídico brasileiro. Em seguida, cuida-se da disciplina dos crimes econômicos por meio de seu desenvolvimento na criminologia, no direito penal econômico e na legislação brasileira. Ingressa-se, assim, no cerne da questão: a incidência da presunção de inocência, enquanto princípio fundamental à persecução penal, sobre a criminalização, investigação e processamento penal dos crimes contra a ordem econômica.

\section{Palavras-chave: Presunção de inocência; Processo penal; Direito penal constitucional; Direito penal econômico; Crimes econômicos; Crimes de colarinho branco.}

\begin{abstract}
In this work, occurs the analysis of the inherent values of the presumption of innocence, by its history, dimensions and reception in the Brazilian legal system. Next, the discipline of the economic crimes is addressed, by its development in the criminology, the criminal economic law, and the Brazilian legislation. Therefore, enters the crux of the matter: the incidence of the presumption of innocence, as a fundamental principle to the criminal prosecution, on the criminalization, investigation and processing of crimes against the economic order.
\end{abstract}

Keywords: Presumption of innocence; Criminal procedure; Criminal Constitucional Law; Criminal Economic Law; Economic crimes; Whitecollar crimes. 


\section{Sumário}

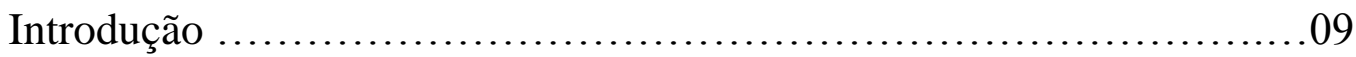

1. Da presunção de inocência .........................................15

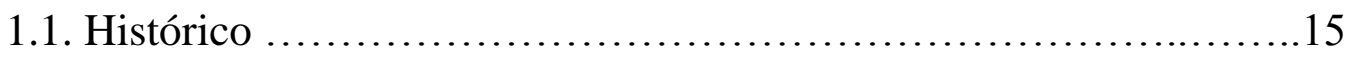

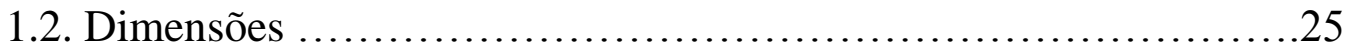

1.2.1. Regra de garantia ..............................................

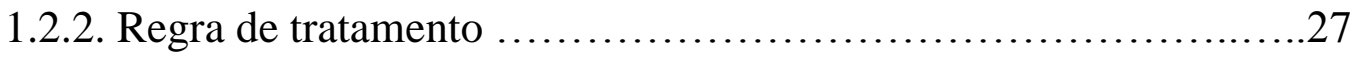

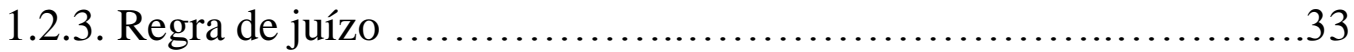

2. Dos crimes econômicos .............................................42

2.1. Construção criminológica ........................................42

2.2. Construção jurídica .................................................49

2.3. Disciplina legal ............................................. 56

3. Da seletividade reversa no combate à impunidade ...................63

3.1. Aspectos penais .............................................. 67

3.1.1. Crimes de perigo abstrato ...................................67

3.1.2. Normas penais em branco ....................................72

3.2. Aspectos processuais penais .................................... 75

3.2.1. Medidas cautelares ............................................ 75

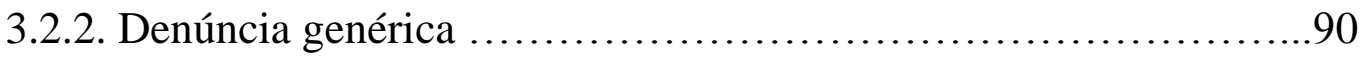

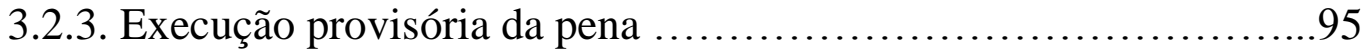

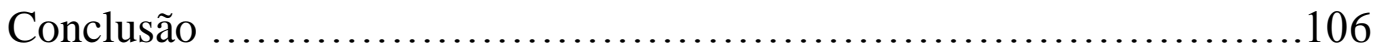

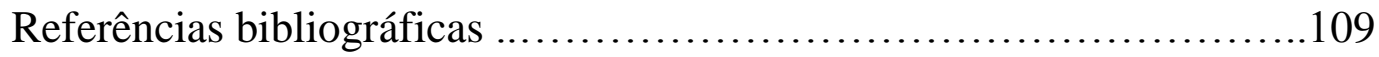




\section{Abreviações}

CADE - Conselho Administrativo de Defesa Econômica

CADH - Convenção Americana de Direitos Humanos

CEDH - Convenção Europeia de Direitos Humanos

CP - Código Penal

CPP - Código de Processo Penal

CRFB - Constituição da República Federativa do Brasil

CVM - Comissão de Valores Mobiliários

DDHC - Declaração

DUDH - Declaração Universal de Direitos do Homem

LEP - Lei de Execução Penal

SDE - Secretaria de Direito Econômico

STF - Supremo Tribunal Federal

STJ - Superior Tribunal de Justiça 


\section{No caminho com Maiakóvski}

"(...)

$\mathrm{Na}$ primeira noite eles se aproximam

e roubam uma flor

do nosso jardim.

E não dizemos nada.

Na segunda noite, já não se escondem; pisam as flores, matam nosso cão, e não dizemos nada.

Até que um dia, o mais frágil deles entra sozinho em nossa casa, rouba-nos a luz, e, conhecendo nosso medo, arranca-nos a voz da garganta. E já não podemos dizer nada.

(Eduardo Alves da Costa) 


\section{Introdução}

A beleza do direito é que ele pode ser, ao mesmo tempo, a arma e a armadura de seus operadores. No âmbito do direito penal, há quem diga que este exprime o direito do Estado à persecução dos criminosos com vistas ao bem comum, enquanto há quem defenda que ele consiste no direito do indivíduo que limitar o poder persecutor do Estado.

Segundo as correntes legitimadoras da prática punitiva, o direito é arma. A teoria da pena parte do pressuposto de que não se pode abrir mão da pena, e busca dar sentido a ela, ao dizer, conforme a teoria mista, que o direito penal possuiria funções retributiva e preventiva - a segunda tanto no plano geral, quanto às demais pessoas, quanto no plano especial, quanto ao agente criminoso.

As teorias criminológicas retributivas entendem o direito de punir como direito absoluto do Estado de retribuir o mal causado pela conduta criminosa. Segundo Immanuel Kant, a pena seria imperativo categórico moral, no sentido de que quem fez o mal merece o mal, ainda que para tal deva-se chegar às últimas consequências - fiat justitia pereat mundus.

Já para Georg Hegel, a pena se fundamentaria na soberania estatal, uma vez que o crime seria a negação do direito positivado pelo soberano, e a pena seria seu instrumento de negação do crime e, assim, de reafirmação do direito imposto. 
A partir do Iluminismo, entende-se que a pena teria, também, função utilitária. De acordo com Jeremy Bentham, deve-se tentar distribuir a maior felicidade possível com o menor sofrimento, e esse sofrimento mínimo deveria fazer bem para a sociedade, também na medida do possível. Ou seja, a pena que, por si só, é má, serviria para proporcionar um bem maior, que é a prevenção de crimes futuros e a defesa social.

Paul Feuerbach, redator do Código Penal da Baviera de 1813, sustentava que a pena teria função de prevenção geral negativa, ou seja, serviria para que os demais indivíduos da sociedade se sentissem desencorajados a praticar condutas criminosas.

Já corrente funcionalista argumenta que a pena reforçaria a ordem jurídica e os valores morais que lhe conferem credibilidade, por meio da restauração da vigência da norma violada, bem como da confiança dos cidadãos nas instituições. Nessa lógica, a pena serviria como um exemplo positivo, para que aquelas pessoas que não cometeram crimes se sintam recompensadas pela manutenção da ordem.

Ainda nesse sentido, o funcionalismo de Niklas Luhmann defendeu que enquanto cada indivíduo cumprir sua expectativa social, a sociedade é harmônica, e que quando um determinado indivíduo para de cumprir com essa expectativa, passa a existir um desequilíbrio anômico que acarreta em práticas criminosas.

Já para as correntes limitadoras ou deslegitimadoras, o direito é armadura. $\mathrm{O}$ direito penal garantiria a anterioridade da lei penal e impediria a criação de tribunais de exceção, enquanto o direito processual penal estabeleceria as regras do jogo democrático de investigação e processamento dos acusados. 
A corrente minimalista se situa entre as teorias legitimadoras e não legitimadoras, porque aceita o direito penal como necessário, porém sob a concepção de que este deve ser mínimo, e utilizado como ultima ratio, ou seja, apenas quando insuficientes, e após esgotados, os demais meios disponíveis.

De acordo com a corrente abolicionista, a pena, sob pretexto de fazer o bem, reproduz a violência dentro da sociedade. Louk Hulsman sustenta a paulatina abolição do processo penal até que se entenda outra maneira de retribuir ao crime.

Já para a corrente garantista, encabeçada por Luigi Ferrajoli, o direito penal deve ser instrumento de contenção do poder estatal em face das garantias individuais do acusado, para se alcançar um mínimo legítimo de punição.

Por meio da teoria negativa, Nilo Batista e Raúl Zaffaroni defendem que o poder punitivo não se legitima com nenhum fim ou fundamento, porquanto é um fato do poder, aliado ao exercício de soberania, cabendo ao direito penal limitar a sua imposição, no interesse da segurança jurídica, concebida esta como segurança dos bens individuais e coletivos.

Nesse diapasão, a presunção de inocência seria justamente uma dessas regras fundacionais para limitar o ius persequendi e puniendi do Estado. Analisando-se a evolução histórica da presunção de inocência, é possível depreender que, não por coincidência, ela incide mais fortemente nos sistemas políticos e jurídicos em que se tutelam as liberdades dos indivíduos da sociedade em questão, e costuma ser mitigada ou desconsiderada quanto mais autocrático o regime. 
Dessa forma, pode-se até mesmo aduzir que a forma como a presunção de inocência é tratada em um determinado local e tempo é um excelente indicativo do quanto as outras garantias serão tratadas. A presunção de inocência, como princípio constitucional insculpido no artigo $5^{\circ}$, LVII, da CRFB, somente pode existir plenamente em um Estado de Democrático de Direito, como pretende a Constituição Federal brasileira.

Contudo, denota-se que a Carta Magna brasileira é nominal e não normativa, ou seja, não há adequação entre o texto normativo e a realidade social. A má gestão, a corrupção, a situação vergonhosa do sistema educacional, os diversos aspectos do processo penal como, por exemplo, o instituto da prisão preventiva, e a condição deplorável de superlotação do sistema prisional brasileiro, que mais alicia o preso à reincidência do que o reinsere na sociedade, formam um círculo vicioso de incentivo à criminalidade.

O direito econômico, especificamente, procura manter a confiança dos cidadãos na ordem econômica, tendo em vista que o sistema financeiro nacional depende de confiança para operar. Logo, os crimes econômicos consistiriam em uma quebra da confiança qualificada, porque ocorrida no âmbito de um sistema que se rege pela confiança, o que justificaria, por exemplo, que uma pena-base fosse aumentada em sentença devido à gravidade do dano causado pelo delito.

Após algumas ações penais de grande repercussão, como o Mensalão, foi deflagrada uma nova fase de combate à corrupção e aos demais crimes de colarinho branco com a celebrada Operação Lava-Jato, na medida em que foram desbaratados complexos esquemas de diversas organizações criminosas que haviam sequestrado não apenas as riquezas contidas nos cofres públicos, como a própria democracia, por meio do famigerado "caixa $2 *$, consistente no financiamento ilegal de campanhas eleitorais. 
Nesse momento de profunda polarização e mobilização da população brasileira, muito se fez para garantir a punição exemplar dos empresários e políticos envolvidos nos escândalos. Isso porque, na medida em que a opinião pública clamava pelo fim da impunidade e pela cessação do sentimento de insegurança e, frente à falência moral e institucional dos Poderes Legislativo e Executivo, ainda assim se verificavam debilidades na persecução penal.

É que existem dificuldades intrínsecas à investigação criminal daqueles que cometeram crimes de natureza econômica, bem como à ação e execução penal, eis que a situação econômica dos acusados permite a contratação de advogados particulares que, dentre outras estratégias, podem se utilizar dos recursos cabíveis de forma protelatória para alcançar o marco prescricional da pretensão punitiva. Passou-se a pleitear, então, a relativização de seus direitos porquanto ausente a condição de vulnerabilidade, que até então justificava a tutela do direito penal de garantias.

Foi então que, em meio ao clamor social de 2016, o Supremo Tribunal Federal tomou as rédeas da situação no julgamento do HC no ${ }^{\circ} 126.292 / S P$, e aumentou o rigor do sistema punitivo brasileiro como um todo, ao permitir que a pena, pelo cometimento de quaisquer crimes, pudesse começar a ser cumprida de forma provisória, desde que garantido o duplo grau de jurisdição por acórdão condenatório de tribunal, retomando a interpretação que imperava até 2009, em interpretação dada conforme à Constituição Federal de 1988.

Nessa retroação, o Ministro Celso de Mello alertou que mitigar garantias não diminuiria a impunidade. Ademais, frisou que o que pode parecer uma dicotomia entre um direito individual à liberdade e o direito da 
sociedade à efetividade da lei penal através da aplicação antecipada da pena, na verdade é um conflito entre dois direitos da sociedade como um todo.

A forte concepção do direito penal como o direito do inimigo causa nos cidadãos a leviana impressão de que nunca seriam afetadas por ele. Porém, a cada flexibilização de um direito individual, mais um passo se dá em direção a um Estado autocrático, especialmente se ela é feita pelas vias institucionais, o que dá ainda mais legitimidade a um poder punitivo abusivo.

Uma vez alimentado o Leviatã, torna-se difícil vencê-lo. Essencial, assim, que se perceba que o direito à liberdade, apesar de em tese individual, é também coletivo, porque a violação a um direito de liberdade do indivíduo é violação ao direito de toda a coletividade. Neste diapasão, o poema "No Caminho com Maiakóvski”, de Eduardo Alves da Costa.

É com essa breve contextualização que se passa a discorrer, especificamente, sobre qual deve ser a posição do Judiciário frente à seguinte questão: até que ponto, e em que medida, a presunção de inocência pode ou deve ser relativizada para garantir a persecução penal daqueles que, supostamente, cometeram crimes econômicos. 


\section{Da presunção de inocência}

\section{I.1. Histórico}

A presunção de inocência consiste em uma garantia de que o acusado deve ser considerado inocente até que comprovada a sua culpabilidade. $\mathrm{O}$ professor-doutor Kenneth Pennington ${ }^{1}$ ensina que, desde a Alta Idade Média e o direito canônico, noções dessa máxima apareciam com vistas a combater o modelo punitivo vigente em grande parte do território europeu.

Naquele período de fragmentação política, a Igreja Católica despontava como o único poder dotado de integridade e institucionalização, legitimando-se para (i) criar regras de conduta social por meio da interpretação dos textos sagrados, e (ii) coagir os indivíduos ao cumprimento dessas regras por meio das punições, que se davam na forma de ordálias e execuções sumárias.

Pennington aponta que, por volta de 1150, o jurista Paucapalea retirou da própria Bíblia Sagrada os fundamentos para a garantia do devido processo. No livro Gênesis, denotou que, em que pese onisciente e onipresente, Deus instaurou um processo para julgamento de Adão, tendo convocado-o, acusado-o e ouvido suas justificativas para ter cometido o crime de alimentarse do fruto proibido.

Já no Deutoronômio, verificou que Moisés estabeleceu uma regra probatória para o sistema processual chancelado por Deus, ao decretar que a verdade poderia ser encontrada no relato de duas ou três testemunhas.

\footnotetext{
${ }^{1}$ PENNINGTON, Kenneth. Innocent Until Proven Guilty: The Origins of a Legal Maxim, 63 JURIST: STUD. CHURCH L. \& MINISTRY 106, 2003.
} 
Sob estes argumentos, o professor verificou que a presunção de inocência foi recepcionada pelo direito eclesiástico e passou a se consolidar como princípio geral, por volta do século 13, na jurisprudência do ius commune e no direito positivado, com a Magna Carta inglesa de 1215 e, na virada do século 14, passou a ser defendida como ius gentium, direito absoluto e natural, ${ }^{2}$ transcendente à vontade dos príncipes/juízes.

Relata que, ironicamente, foi o canonista Johannes Monachus o primeiro jurista europeu a reconhecer, nessa época, a presunção de inocência como consequência lógica do julgamento divino de Adão — ora, se nem Deus poderia condenar sem um julgamento prévio, seria porque ele deveria presumir que Adão fosse inocente até que comprovado culpado.

Registra-se ainda que, em 1398, o inquisidor francês Johannes de Pogiali fundamentou uma absolvição por ausência de provas, concluindo que era melhor deixar um crime sem punição do que condenar uma pessoa inocente - justamente a premissa máxima da presunção de inocência.

Despontou-se, assim, um processo de racionalização da pretensão punitiva em observância à garantia do processo, que gerou o modelo de julgamento inquisitorial. Decerto, conquistado o direito a ser processado, ainda se estava longe de um devido processo que concretizasse o direito de defesa.

O modelo inquisitório era marcado por uma profunda desigualdade entre a acusação, que se dava na pessoa do próprio juiz, e a defesa do acusado,

\footnotetext{
${ }^{2}$ Naquela época, imperava a concepção que identificava o direito divino e o direito natural. Foi justamente o fundamento religioso, nesse caso, que revestiu a presunção de inocência de caráter absoluto, porquanto Deus legitimava a autoridade dos príncipes e dos juízes. Seria, então, teratológico que as autoridades mundanas pudessem ignorar os mandamentos divinos. Segundo Pennington, até então, entendia-se como direito do príncipe ou do juiz de ignorar as regras do processo judicial, eis que consideravam o processo legal como parte do direito civil positivado e, assim, sujeito às arbitrariedades das autoridades.
} 
conforme se depreende de diversos aspectos, notadamente: pelo sistema de provas tarifadas e livre convencimento do juiz, pela valoração da confissão como prova plena, pela prática de tortura para obtenção de confissões, pela obrigatoriedade da prisão processual e pela admissão de denúncias e testemunhas secretas.

Nos séculos 14 a 17, observou-se o desenvolvimento da presunção de inocência para além da mera garantia do processo em diversos documentos eclesiásticos. Em declarações papais como a do Papa Sixtus IV, em 1482, defendia-se o direito natural à defesa por meio da representação por advogado, e da apresentação de exceções e provas perante a corte, de modo que a violação desses direitos ensejaria apelação a Roma.

Já em 1764, o filósofo político italiano Cesare Beccaria ${ }^{3}$ se filiava à concepção contratualista, defendendo que o poder conferido ao Estado para organização da sociedade importaria em um poder para efetivamente estabelecer, através de leis, as condutas proibidas.

As penas seriam, então, uma forma de punição aos intransigentes, para defender o regime jurídico contra usurpações de particulares. Porém, Beccaria defendia que o castigo que não decorresse de uma necessidade absoluta seria tirânico e, assim, as penas seriam tão justas quanto mais sagrada e inviolável fosse a segurança que proporcionassem.

Nesse sentido, o poder de punir deparava-se com alguns limites que já exprimiam nuances da presunção de inocência, como (i) a necessidade de mais de uma testemunha de acusação para se verificar a ocorrência de crime, porque a palavra do acusado e da testemunha teriam mesmo valor, e restaria dúvida que beneficiaria o acusado, e (ii) a vedação à tortura do investigado

\footnotetext{
${ }^{3}$ BECCARIA, Cesare Bonesana. Dos delitos e das penas. Tradução de Flório de Angelis. 2. Reimpr. São Paulo: EDIPRO, 1999.
} 
ou acusado com vistas a obter eventual confissão, porque não se deve atormentar aquele que não teve seus crimes comprovados.

Sob a influência de Beccaria e do movimento iluminista, ${ }^{4}$ a revolução francesa cunhou a Declaração de Direitos do Homem e do Cidadão de 1789 - DDHC, que estabeleceu em seu artigo $9^{\circ},{ }^{5}$ enquanto direito natural, inalienável e sagrado do homem, que todo acusado deveria ser tratado como inocente, no ínterim existente entre a acusação e a sentença, até ser declarado culpado.

Dessa forma, inaugura-se a moderna dogmática jurídica garantista, que defendeu uma nova forma de pensar o direito com vistas à humanização das práticas punitivas, esta respaldada por um sistema de garantias inerentes à condição humana. $\mathrm{O}$ argumento passou a ser a proteção contra o poder punitivo estatal, devido ao inerente desequilíbrio entre as partes no processo penal.

O processo sob o modelo acusatório instituiu, assim, a relação triangular entre juiz, acusação e defesa, o que proporciona as condições necessárias para um juízo imparcial sobre a culpabilidade do acusado. Segundo Aury Lopes Jr.:

"....] a imparcialidade é garantida pelo modelo acusatório e sacrificada no sistema inquisitório, de modo que somente haverá condições de possibilidade da imparcialidade quando existir, além da separação inicial das funções de acusar e julgar, um afastamento do juiz da atividade investigatória/instrutória. [...] A

\footnotetext{
${ }^{4}$ Para os filósofos e juristas da época, era necessário corrigir o desequilíbrio do irrefreado poder punitivo, característico do absolutismo. Dentre os traços do pensamento iluminista, insta ressaltar o humanismo, que buscava o reconhecimento de valores e direitos intrínsecos à qualidade de ser humano, por meio da declaração de direitos naturais ao cidadão, auferidos pelo racionalismo humano, e não mais pelo dogmatismo religioso.

${ }^{5}$ Artigo $9^{\circ}$, DDHC. “Todo acusado é considerado inocente até ser declarado culpado e, caso seja considerado indispensável prendê-lo, todo o rigor desnecessário à guarda da sua pessoa deverá ser severamente reprimido pela lei."

${ }^{6}$ LOPES JR., Aury. Direito Processual Penal - 13 ed. - São Paulo: Saraiva, 2016, pp. 63-64.
} 
imparcialidade do juiz fica evidentemente comprometida quando estamos diante de um juiz-instrutor (poderes investigatórios) ou quando lhe atribuímos poderes de gestão/iniciativa probatória. É um contraste que se estabelece entre a posição totalmente ativa e atuante do instrutor, contrastando com a inércia que caracteriza o julgador. Um é sinônimo de atividade, e o outro, de inércia."

Gustavo Badaró, por sua vez, alerta que o Estado possui meios institucionalizados de fiscalização, disciplina, investigação e acusação dos indivíduos, dos quais a defesa não dispõe, de modo que "a missão de igualar os desiguais é atribuída ao juiz e, assim, o contraditório não só permite a atuação das partes, como impõe a participação do julgador," inaugurando o ativismo judicial em favor da isonomia processual. ${ }^{7}$

Pouco após, o Código Napoleônico de 1808 inaugurou o modelo acusatório, o qual previa a clara distinção entre as funções de julgar e acusar, em busca da imparcialidade do juiz, e da paridade de armas. Para tanto, foram estabelecidos meios efetivos para o exercício do direito a resistir à pretensão punitiva: o contraditório, a distribuição do ônus probatório, o sistema de livre convencimento motivado do juiz, e o direito à impugnação e ao duplo grau de jurisdição.

Mônica Ovinski narra que a presunção de inocência seguiu sendo assunto de embates jurídicos, em especial nas Escolas Penais italianas. ${ }^{8}$ Conta que, entre os séculos XVIII e XIX, ápice do Estado Moderno capitalista, surgiu a Escola Clássica de Francesco Carrara, de cunho liberal, que pugnava por um Judiciário neutro, em observância à estrita legalidade nullum crimen nula poena sine lege -, bem como ao devido processo - nulla poena sine judicio.

\footnotetext{
${ }^{7}$ BADARÓ, Gustavo Henrique. Processo Penal - 5 ed. rev., atual e ampl. - São Paulo: Editora Revista dos Tribunais, 2017, pp. 56-57.

${ }^{8}$ OVINSKI, Mônica. O Estado e o Indivíduo: o conflito entre punir e libertar - história da presunção de inocência no Brasil (1948 - 2000). 2001. Dissertação (Mestrado em Direito). Centro de Ciências Jurídicas, Universidade Federal de Santa Catarina, Santa Catarina.
} 
Ademais, Carrara sustentava que, entre proteger os direitos do acusado ou puni-lo, o Estado deveria priorizar a tutela dos direitos individuais, favorecendo-o. Para tanto, a presunção de inocência não seria um mero princípio processual penal, mas sim seu conceito fundamental ${ }^{9} \mathrm{e}$ ponto de legitimidade, porquanto deveria incidir inevitavelmente sobre todos os atos processuais.

A Escola Positiva de Ferri, por sua vez, tornou-se retrato do momento político da segunda metade do século XIX, marcado pelo crescente intervencionismo estatal e nacionalismo. Apesar de reconhecer a presunção de inocência, Ferri negou sua centralidade e seu sentido absoluto, e apontou o medo gerado na população ao se permitir que um criminoso condenado em primeiro grau recorresse em liberdade. Para mais, rechaçou que a presunção de inocência valesse para os acusados reincidentes ou para aqueles em flagrante delito.

Já a Escola Técnico-Jurídica de Arturo Rocco e de Vicenzo Manzini, em meio à efervescência totalitária da primeira metade do século $\mathrm{XX}$, defendia que o processo penal tinha como foco buscar a certeza da culpabilidade e da punibilidade, por meio da produção e valoração das provas. As normas processuais penais não serviriam para proteger a inocência do acusado, mas apenas tutelar suas liberdades individuais, de maneira que seria irrazoável esperar até a irrevogabilidade da sentença condenatória para infligir a pena.

Para Rocco, ${ }^{10}$ a presunção de inocência seria uma “extravagância derivada dos velhos conceitos, nascidos da Revolução Francesa." O

\footnotetext{
${ }^{9}$ A adjetivação que se pretende, aqui, significa não apenas que o princípio da presunção de inocência seja essencial, mas que é o fundamento, o alicerce do processo penal de garantias.

${ }^{10}$ ROCCO, Arturo. Apud. OVINSKI, Mônica. O Estado e o Indivíduo: o conflito entre punir e libertar - história da presunção de inocência no Brasil (1948 - 2000). 2001. Dissertação (Mestrado em Direito). Centro de Ciências Jurídicas, Universidade Federal de Santa Catarina, Santa Catarina.
} 
indivíduo não teria status de inocente nem de culpado no processo penal, mas assumiria uma posição neutra, de indiciado ou acusado, no qual estaria suspenso seu estado natural de inocência até a certeza ou negação de sua culpabilidade ao fim do processo - o que justificaria, por exemplo, a permissão legal para adoção de medidas cautelares, como a prisão preventiva do acusado.

Tendo em vista os diversos conflitos territoriais, foi apenas no fim da Segunda Guerra Mundial que a Assembleia Geral das Nações Unidas proclamou a Declaração Universal dos Direitos Humanos de 1948 - DUDH que, em seu artigo $11,{ }^{11}$ reafirmou a presunção de inocência como direito natural, componente do ius cogens internacional. Ademais, o Conselho da Europa adotou a Convenção Europeia dos Direitos Humanos de 1950 CEDH que, em seu artigo $6^{\circ}, \S 2^{\circ}$, prevê a presunção de inocência como parte do direito a um processo equitativo.

Em uma análise dos sistemas penais europeus, Christine Lazerges ${ }^{12}$ aponta as diferentes fontes do direito utilizadas por cada país para fundamentar a presunção de inocência na contemporaneidade. Na Alemanha, explica que a CEDH possui força de lei, mas que a presunção de inocência também é reconhecida pela Corte Constitucional do país enquanto decorrente do princípio do Estado de Direito, consagrado pelo artigo 20 da Lei Fundamental de 1949.

Na França, a presunção de inocência compõe o bloco constitucional estabelecido pela Declaração de 1789, bem como está prevista no artigo 9-I,

\footnotetext{
${ }^{11}$ Artigo 11, DUDH. "I) Todo o homem acusado de um ato delituoso tem o direito de ser presumido inocente até que a sua culpabilidade tenha sido provada de acordo com a lei, em julgamento público no qual lhe tenham sido asseguradas todas as garantias necessárias a sua defesa. II) Ninguém poderá ser culpado por qualquer ação ou omissão que, no momento, não constituiam delito perante o direito nacional ou internacional. Também não será imposta pena mais forte do que aquela que, no momento da prática, era aplicável ao ato delituoso."

${ }^{12}$ LAZERGES, Christine. La présomption d'innocence en Europe, Archives de politique criminelle, vol. 26, no. 1, 2004, pp. 125-138.
} 
alínea 1, do Código Civil, e consta dentre os princípios diretores do Código de Processo Penal. Já na Itália, além da CEDH, figura sob o termo presunção de não culpabilidade no artigo 27 da Constituição Italiana. Na Espanha, de forma parecida, reconhece-se a presunção de inocência pela CEDH e pelo artigo 24-2 da Constituição Espanhola.

Ressalta, ainda, que enquanto os Países Baixos utilizam a CEDH como fonte direta da presunção de inocência sem maiores complicações, a Inglaterra não internalizou a $\mathrm{CEDH}$ em seu ordenamento jurídico, de forma que os juizes têm de interpretar o direito interno, composto pela Carta de 1215 e pelo Human Rights Act de 1998, à luz da Convenção, e ela pode ser oposta em face de disposições legislativas contrárias.

Aduz Ovinski ${ }^{13}$ que a sensível trajetória do Brasil na internalização da presunção de inocência se iniciou com a adesão brasileira à Declaração Universal dos Direitos do Homem de 1948. Nessa primeira fase, ela teria sido acatada pela doutrina e jurisprudência na forma do in dubio pro reo e do favor rei, que visam mormente a dimensão probatória.

Em seguida, com a deflagração do golpe militar de 1964, o autoritarismo teria suprimido a presunção de inocência, com fundamento na doutrina da segurança nacional e nos atos institucionais permissivos à violência estatal. Após iniciada a redemocratização na década de 1980, verificou-se a emergência da presunção de inocência na jurisprudência dos tribunais superiores, sinalizando os novos tempos.

O modelo de execução penal consagrado pela Lei $n^{\circ} 7.210 / 1984$, a famigerada Lei de Execução Penal - LEP, já preceituava a presunção de inocência nos seguintes dispositivos: (i) artigo 105, que condicionou a

\footnotetext{
${ }^{13}$ OVINSKI, Mônica. O Estado e o Indivíduo: o conflito entre punir e libertar - história da presunção de inocência no Brasil (1948 - 2000). 2001. Dissertação (Mestrado em Direito). Centro de Ciências Jurídicas, Universidade Federal de Santa Catarina, Santa Catarina.
} 
execução da pena privativa de liberdade ao trânsito em julgado da sentença condenatória; (ii) artigo 147, que assim também condicionou a execução da pena restritiva de direitos; (iii) artigo 164, que estabeleceu a validade de título executivo judicial à certidão da sentença condenatória transitada em julgado.

Na Constituição Federal de 1988, a presunção de inocência foi insculpida no artigo $5^{\circ}$, LVII, no rol de garantias fundamentais ao indivíduo, e na forma de um princípio com valor democrático, ao determinar que ninguém deverá ser considerado culpado antes do trânsito em julgado de sentença penal condenatória.

Há de se ressaltar, desde logo, que a regra prevista neste inciso não esgota a presunção de inocência, uma vez que ela permeia as demais garantias à defesa do acusado, mas chancela o princípio da presunção de inocência dentre as garantias fundamentais, e portanto constitui cláusula pétrea, revestida de proteção especial pelo artigo $60, \S 4^{\circ}, \mathrm{IV}$, da Constituição Federal. ${ }^{14}$

Ao interpretar este dispositivo, Maria Lucia Karam reafirma que a presunção de inocência consista em um direito fundamental, na medida em que garante, até o trânsito em julgado de sentença condenatória, que seja dispensado ao acusado um tratamento igualitário em relação aos demais indivíduos da sociedade em estado de inocência o que, portanto, seria o mesmo que respeitá-lo enquanto ser humano dotado de dignidade. ${ }^{15}$

\footnotetext{
${ }^{14}$ Artigo 60, $\S 4^{\circ}$ da CRFB. “Art. 60. A Constituição poderá ser emendada mediante proposta: $\S 4^{\circ}$ Não será objeto de deliberação a proposta de emenda tendente a abolir: I - a forma federativa de Estado; II - o voto direto, secreto, universal e periódico; III - a separação dos Poderes; IV - os direitos e garantias individuais".

${ }^{15}$ KARAM, Maria Lúcia. Escritos sobre a Liberdade Volume 5: liberdade, presunção de inocência e direito à defesa. Rio de Janeiro: Editora Lumen Juris, 2009.
} 
Em razão do sedimentado princípio da supremacia da Constituição, ${ }^{16}$ a presunção de inocência enquanto princípio constitucional vaza para todo o ordenamento jurídico, permeando assim o Código Processual Penal, bem como as leis penais extravagantes. Exemplifica-se o caloroso debate sobre a recepção constitucional do ora revogado artigo 594 do CPP, que previa, como requisitos alternativos para a apelação, que o réu reincidente ou de maus antecedentes se recolhesse à prisão ou prestasse fiança. ${ }^{17}$

No mais, denota-se que alguns doutrinadores contemporâneos, como Paulo Rangel e Luis Gustavo de Carvalho, sustentam que a Constituição chancelou, de fato, a presunção de não culpabilidade, eis que a literalidade do dispositivo constitucional não presume de fato a inocência, e sim veda a presunção de culpa, na medida em que exige a certeza da culpa declarada judicialmente para que o indivíduo possa ser considerado culpado. ${ }^{18}$

Além disso, tem-se que o mais recente parâmetro legal sobre a presunção de inocência no ordenamento jurídico brasileiro se deu com a internalização, em 1992, da Convenção Americana sobre Direitos Humanos - CADH, comumente denominada Pacto de São José da Costa Rica, que prevê em seu artigo $8^{\circ}, \S 2^{\circ}$, apenas que todo acusado tem direito a que se presuma sua inocência enquanto não se comprove legalmente sua culpa e que, durante o processo, tem direito a garantias judiciais mínimas. ${ }^{19}$

\footnotetext{
${ }^{16}$ O princípio da supremacia da Constituição, segundo Ferreira Filho, "decorre de sua origem. Provém ela de um poder que institui a todos os outros e não é instituído por qualquer outro, de um poder que constitui os demais e é por isso denominado Poder Constituinte". FERREIRA FILHO, Manoel Gonçalves. Curso de direito constitucional. 27 Ed. São Paulo: Saraiva, 2001, p. 20-21.

${ }^{17}$ Artigo 594 do CPP (revogado). "O réu não poderá apelar sem recolher-se à prisão, ou prestar fiança, salvo se for primário e de bons antecedentes, assim reconhecido na sentença condenatória, ou condenado por crime de que se livre solto". A discussão foi dirimida com a Lei no 11.719/2008, que revogou expressamente o referido dispositivo.

${ }^{18}$ RANGEL, Paulo apud PILONI, Caroline de Paula Oliveira. Princípio da não-culpabilidade: aspectos teóricos e práticos. Revista Jus Navigandi, ISSN 1518-4862, Teresina, 2013 Disponível em: <https://jus.com.br/artigos/25467>. Acesso em: 30 out. 2018.

${ }^{19}$ Cumpre lembrar que a CADH foi internalizada no ordenamento jurídico brasileiro em 1992, portanto anteriormente à Emenda Constitucional n ${ }^{\circ}$ 45/2004. Dessa forma, não cumpriu o quórum qualificado de três quintos de aprovação das emendas constitucionais, e portanto não é possível
} 
Com base na análise histórica, observa-se que o poder punitivo do Estado não depende de um processo para se realizar, porquanto existiram outros meios, inclusive mais efetivos, para se chegar à punição dos criminosos. O processo penal concebido enquanto meio para se chegar à punição pode até admitir a presunção de inocência, mas apenas enquanto um princípio defensivo, sem caráter absoluto.

Contudo, também se denota que o próprio processo penal é uma conquista da luta da humanidade ocidental, iniciada ainda na Idade Média, pelo reconhecimento da presunção de inocência dos acusados. A presunção de inocência é, portanto, princípio absoluto e fundamental do processo penal, sendo certo que as garantias nele tuteladas também dela decorrem.

\section{I.2. Dimensões}

Rubens Casara entende a presunção de inocência como um princípio fundamental, cuja concretização se realiza em três dimensões: (i) regra de garantia, limitadora do poder estatal, freando potenciais abusos ou excessos; (ii) regra de tratamento como se inocente fosse, conferido ao indiciado ou réu; (iii) regra de juízo para apreciação das provas à luz do in dubio pro reo, vedada a inversão do ônus probatório. ${ }^{20}$

\footnotetext{
garantir-lhe o status equiparado ao de emenda constitucional. Todavia, por ser um tratado que versa sobre matéria de direitos humanos, possui status diferenciado, nos termos do artigo $5^{\circ}$, § $2^{\circ}$, da CRFB. O STF sedimentou o entendimento de que, nesses casos, os tratados de direitos humanos não poderiam se equiparar às leis ordinárias sob pena de esvaziar o conteúdo normativo do dispositivo supracitado e, assim, confere a esses tratados o status de norma supralegal e infraconstitucional - a título exemplificativo: Rext nos 466.343 e 349.703 , e $\mathrm{HCs} \mathrm{n}^{\circ}$ 87.638, 87.585 e 90.172 .

${ }^{20}$ CASARA, Rubens. Uma ilustre desconhecida: a presunção de inocência. 2015. Disponível em: $<$ http://justificando.cartacapital.com.br/2015/01/17/uma-ilustre-desconhecida-presuncao-deinocencia/>.
} 


\section{I.2.1. Regra de garantia}

Em sua primeira dimensão, trata-se de um instrumento de proteção da pessoa acusada frente a possíveis arbitrariedades do Estado no exercício dos poderes persecutório e punitivo. Logo, o juiz não deve enxergar o acusado com suspeita ou descrédito (regra de tratamento), e órgão acusatório deve produzir as provas suficientes para superar a presunção de inocência e comprovar, sem resquício de dúvidas, a culpabilidade do acusado (regra de juízo).

Nesse sentido, Eugênio Pacelli entende se tratar de um princípio estrutural que leva à concretização jurídica do estado de inocência, assim entendido como: ${ }^{21}$

.....] posição do sujeito diante das normas da ordenação, resultando também direitos subjetivos públicos a serem exercidos em face do Estado, que haverá de justificar sempre ou em lei ou/e motivadamente - quando judicial a decisão quaisquer restrições àqueles direitos".

A regra de garantia se constitui, portanto, de dois lados de uma mesma moeda: (i) o acusado pode opor ao poder público direitos subjetivos decorrentes de seu inabalado estado de inocência, freando possíveis abusos; (ii) o Estado deve espontaneamente adotar todas as medidas necessárias para assegurar que o acusado tenha o mínimo de direitos restringidos, tanto na criminalização de sua conduta, quanto durante a investigação e o processo criminal.

Impõe-se ao Estado posicionamentos garantistas em dois aspectos: penal, por meio dos princípios da anterioridade da lei penal, da legalidade formal e da taxatividade; processual penal, em observância aos princípios da

\footnotetext{
${ }^{21}$ OLIVEIRA, Eugênio Pacelli apud CASARA, Rubens. Uma ilustre desconhecida: a presunção de inocência. 2015. Disponível em: <http://justificando.cartacapital.com.br/2015/01/17/uma-ilustredesconhecida-presuncao-de-inocencia/>.
} 
inafastabilidade da jurisdição, da motivação das decisões judiciais, do devido processo legal, da ampla defesa e do contraditório.

Casara ressalta ainda que o princípio da presunção de inocência, no contexto atual: ${ }^{22}$

.....] deve servir como óbice e constrangimento às tentações totalitárias (de fazer do imputado um objeto a ser manipulado pelo Estado) e às perversões inquisitoriais que levam ao encarceramento em massa da população brasileira, em especial aqueles que não interessam à sociedade de consumo."

\section{I.2.2. Regra de tratamento}

A segunda dimensão da presunção de inocência exprime um componente da ética pessoal do cidadão brasileiro, determinando que ele olhe para o outro despido de medo ou reprovação. $\mathrm{O}$ valor democrático reside em olhar a pessoa como uma pessoa, e não como um inimigo, criminoso, vedando assim a estigmatização sumária por parte da população e da mídia. Conforme ensina Aury Lopes Jr.: ${ }^{23}$

"Externamente ao processo, a presunção de inocência exige uma proteção contra a publicidade abusiva e a estigmatização (precoce) do réu. Significa dizer que a presunção de inocência (e também as garantias constitucionais da imagem, dignidade e privacidade) deve ser utilizada como verdadeiros limites democráticos à abusiva exploração midiática em torno do fato criminoso e do próprio processo judicial. O bizarro espetáculo montado pelo julgamento midiático deve ser coibido pela eficácia da presunção de inocência."

Nesse diapasão, Simone Schreiber aponta precedentes em que a Suprema Corte norte americana anulou julgamentos criminais em ambiente de grande repercussão e comoção popular, os chamados trial by media, em

\footnotetext{
${ }^{22}$ CASARA, Rubens. Uma ilustre desconhecida: a presunção de inocência. 2015. Disponível em: $<$ http://justificando.cartacapital.com.br/2015/01/17/uma-ilustre-desconhecida-presuncao-deinocencia/>.

${ }^{23}$ LOPES JR., Aury. Direito Processual Penal - 13 ed. - São Paulo: Saraiva, 2016, p. 97.
} 
que não foram adotadas as medidas necessárias para garantir o fair trial, ou seja, a isenção do resultado do julgamento e o direito à defesa plena. ${ }^{24}$

Além de seu âmbito externo, a presunção de inocência surte efeitos endoprocessuais, significando que o juiz e a acusação devem tratar o acusado como se inocente fosse. É, portanto, uma regra de tratamento processual, que leva o juízo a admitir a impossibilidade prática de remontar a verdade real dos fatos sob apreciação, e a buscar a verdade processual, ou seja, aquela obtida respeitando as regras do procedimento pré-estabelecido.

Nota-se então que a presunção de inocência é reitora de todos os atos pré-processuais e processuais. De início, tem-se que, em 2008, o Supremo Tribunal Federal editou o Enunciado de Súmula Vinculante $n^{\circ} 11$, que restringiu o uso de algemas dos presos aos casos de resistência e de fundado receio de fuga ou de perigo à integridade física própria ou alheia, porque seria uma prática degradante e contrária à presunção de inocência. ${ }^{25}$

\footnotetext{
${ }^{24}$ A autora aponta, dentre outras providências possíveis: (i) o desaforamento; (ii) o adiamento do julgamento; (iii) o sequestro e incomunicabilidade aos jurados; (iv) gag orders. Trouxe, ainda, que na eventualidade de edição de uma lei que regulamentasse a liberdade de imprensa, poderia-se prever algumas medidas contra a publicidade opressiva dos tribunais, por exemplo: (i) a possibilidade de suspensão do processo e da prescrição até que arrefeça o interesse da mídia sobre determinado caso criminal a vedação de introdução de provas produzidas pela mídia no processo; (ii) a adoção do direito de resposta especificamente para situações de trial by media, determinandose às empresas jornalísticas que abram espaço para novas abordagens, esclarecimentos e refutações a respeito das notícias veiculadas, quando demonstrado o caráter prejudicial da cobertura jornalística de determinado fato criminal; (iii) a criação do tipo penal de publicidade opressiva. SCHREIBER, Simone. A publicidade opressiva dos julgamentos criminais. Disponível em http://www.cartaforense.com.br/conteudo/artigos/a-publicidade-opressiva-dos-julgamentoscriminais/4643.

${ }^{25}$ Enunciado de Súmula Vinculante no ${ }^{\circ} 11$, STF. "Só é lícito o uso de algemas em casos de resistência e de fundado receio de fuga ou de perigo à integridade física própria ou alheia, por parte do preso ou de terceiros, justificada a excepcionalidade por escrito, sob pena de responsabilidade disciplinar, civil e penal do agente ou da autoridade e de nulidade da prisão ou do ato processual a que se refere, sem prejuízo da responsabilidade civil do Estado". Em razão desse enunciado, a jurisprudência do Supremo ainda consolidou entendimentos quanto à necessidade de justificativa por escrito pelo magistrado para o uso de algema em réu preso, e à necessidade de justificação por escrito pela autoridade policial para o uso de algema em cumprimento de mandado de prisão temporária.
} 
No ano seguinte, o STF editou o Enunciado de Súmula Vinculante no 14, que consolidou a prerrogativa do defensor de, no interesse do representado, ter franqueado amplo acesso aos elementos de prova já documentados em autos de procedimento investigatório realizado por órgão com competência de polícia judiciária, ressalvadas as diligências sob sigilo, garantindo assim a ampla defesa do investigado. ${ }^{26}$

Ainda em fase pré-processual (mas também processual), fala-se da adoção de algumas medidas de natureza cautelar que restringem direitos do investigado ou acusado. Para que sejam minimamente compatíveis com a presunção de inocência, elas devem ser adotadas com extrema parcimônia e em estrita observância aos limites legais, como se verá adiante.

Ademais, o equilíbrio entre acusação e defesa prevê a paridade de armas, que se dá por meio do direito à defesa técnica, da igualdade de oportunidade e conhecimento, e da utilização de iguais instrumentos. A única possibilidade de tratamento diferenciado seria, portanto, para equilibrar a capacidade argumentativa da defesa do réu frente ao enorme aparato estatal, tanto investigativo quanto acusatório.

Para tanto, se faz necessária a garantia do contraditório, a qual impõe que o autor e o réu devam participar dos atos do processo, franqueando-se à defesa todo o conteúdo probatório existente contra o acusado. Por isso mesmo, trabalha-se com o sistema de persuasão racional que obriga o juiz a fundamentar sua decisão coerente com as provas que teve de cada parte, julgando o processo como um todo.

\footnotetext{
${ }^{26}$ Enunciado de Súmula Vinculante no ${ }^{\circ}$ 14, STF. “É direito do defensor, no interesse do representado, ter acesso amplo aos elementos de prova que, já documentados em procedimento investigatório realizado por órgão com competência de polícia judiciária, digam respeito ao exercício do direito de defesa ". Em razão desse denunciado, a jurisprudência do Supremo ainda consolidou entendimentos quanto à possibilidade de obtenção de todos os elementos de prova já documentados, inclusive daqueles em formato audiovisual, ao direito do acesso pela defesa a provas já concluídas que constem de outro processo, ao contraditório diferido, e à possibilidade de acesso aos depoimentos de testemunhas antes do interrogatório.
} 
A defesa eficaz é a garantia de concessão de advogado pelo Estado a todo réu. Segundo Badaró, “o direito à defesa técnica é exercido por profissional habilitado, com capacidade postulatória e conhecimentos técnicos, assegurando assim a paridade de armas entre a acusação e a defesa. ${ }^{\cdot 27}$

Apesar de ser garantido a todo réu o direito à defesa técnica, ou seja, a um advogado ou defensor público, é sabido que os defensores recebem centenas de processos por mês, enquanto os advogados particulares podem se debruçar em alguns poucos casos.

Ainda que existam qualificados e zelosos defensores públicos, o serviço prestado fica prejudicado pelo excesso de trabalho, na medida em que a instituição vem incorporando novas demandas da sociedade, e a procura da população pelos serviços da instituição se amplia. ${ }^{28}$ Infelizmente, os assistidos pela Defensoria Pública estariam ainda mais longe de ter seus direitos defendidos com efetividade.

Ademais, é certo, que, no início de um processo criminal, costume ser simplório o embasamento probatório e, por isso, mesmo, recebe-se a denúncia quando presentes indícios mínimos de autoria e materialidade. Já no decorrer do processo, a culpabilidade da pessoa acusada seria comprovada, por meio da produção de diversos tipos de prova, que formam a convicção do juiz pela condenação no momento final do procedimento, com a prolação da sentença.

\footnotetext{
${ }^{27}$ BADARÓ, Gustavo Henrique. Processo Penal - 5 ed. rev., atual e ampl. - São Paulo: Editora Revista dos Tribunais, 2017, p. 60.

${ }^{28}$ De acordo com a Associação Paulista de Defensores Públicos, "o resultado desse desequilíbrio são Defensores Públicos cada vez mais assoberbados, com rotinas de trabalho que enveredam noites adentro, pelos fins de semana e feriados, sem uma correspondente remuneração pela carga de trabalho ampliada ou uma estrutura eficiente de suporte". Disponível em: <https://www.apadep.org.br/revista/carreira-enfrenta-excesso-de-trabalho-e-falta-de-estrutura/>
} 
Entretanto, franqueia-se ao acusado o direito ao recurso, o que consubstancia o princípio do duplo grau de jurisdição, implícito no artigo $5^{\circ}$, LV, da CRFB, e previsto no artigo $8^{\circ}, 2$, h, do Pacto de San José da Costa Rica enquanto "direito de recorrer da sentença a juiz ou tribunal superior.."29

Independentemente de quem fosse acusado ou da gravidade do crime cometido, tem-se que o reconhecimento judicial da culpabilidade da pessoa acusada não deve afetar, ainda, seu estado de inocência, mas apenas quando sentença condenatória transitar em julgado, isto é, quando dela não couber mais recurso, nem existir recurso ainda pendente de decisão.

Há entendimento pacífico nos tribunais superiores de que, ao menos até a confirmação da sentença condenatória pelo tribunal de segunda instância, a presunção de inocência se mantém hígida, devido aos efeitos devolutivos e suspensivos inerentes ao recurso de apelação. Assim, esse tribunal pode revisar a sentença em todos os seus aspectos, ou seja, tanto as questões fáticas quanto as questões jurídicas.

O ponto ainda controvertido, e que será abordado mais adiante, trata da permanência ou não do estado de inocência quando restam apenas recursos aos tribunais superiores, que não podem revolver matérias fáticas, mas apenas de direito. Isso porque, em tese, a culpabilidade do acusado, uma vez reconhecida em segunda instância, não poderia mais ser objeto de recurso, e se daria por finda a sua presunção de inocência.

Olvida-se, todavia, que os tribunais superiores podem, em meio à análise das questões de direito do caso, reconhecer ilicitudes que ensejem

\footnotetext{
${ }^{29}$ Artigo $8^{\circ}, 2$, h, CADH. “'Toda pessoa acusada de delito tem direito a que se presuma sua inocência enquanto não se comprove legalmente sua culpa. Durante o processo, toda pessoa tem direito, em plena igualdade, às seguintes garantias mínimas: h- direito de recorrer da sentença para juiz ou tribunal superior".
} 
nulidade da sentença condenatória ou, até mesmo, de todo o processo. Se esses tribunais podem absolver o acusado, não há como se garantir, assim, que o seu estado de inocência se esgotou em segunda instância.

Devido à manutenção do estado de inocência até o trânsito em julgado da sentença penal condenatória, tem-se ainda que a mera existência de inquérito policial ou ação penal em curso, em qualquer fase, não tem o condão de antecedente criminal. Nessa lógica, o Enunciado de Súmula n 444 do STJ veda a utilização de inquéritos policiais e ações penais em curso para agravar a pena-base.

O STF também entendia, até então, que para a comprovação da inidoneidade exigida para o exercício de certas profissões, como a de vigilante, não se poderia exigir a inexistência de registro, na Folha de Antecedentes Criminais, de indiciamento em inquérito policial ou processo criminal, mas apenas a inexistência de condenação em processo criminal. ${ }^{30}$

Contudo, em caso de contratação do poder público, há jurisprudência afirmando que o princípio da presunção de inocência não é absoluto, e deve ser ponderado com outros princípios constitucionais, como o da moralidade administrativa e o da supremacia do interesse público, devendo os últimos prevalecerem para evitar o ingresso no serviço público daqueles que não apresentarem passado absolutamente ilibado. ${ }^{31}$

\footnotetext{
30 “AGRAVO REGIMENTAL NO RECURSO EXTRAORDINÁRIO. CONSTITUCIONAL. PRESUNÇÃO DE INOCÊNCIA. HOMOLOGAÇÃO DE DIPLOMA DE CURSO DE VIGILANTE. AGRAVO REGIMENTAL A QUE SE NEGA PROVIMENTO. I - Viola o princípio da presunção de inocência a negativa em homologar diploma de curso de formação de vigilante, fundamentada em inquéritos ou ações penais sem o trânsito em julgado. II - Agravo regimental a que se nega provimento.” (STF, RE 809.910-AgR, Rel. Min. Ricardo Lewandowski, Segunda Turma, DJe de 15/8/2014). No mesmo sentido: RE no 885.071/RJ, Rel. Min. Luiz Fux, DJe 6.8.2015; $\mathrm{RE} \mathrm{n}^{\circ}$ 827.546/PE, Rel. Min. Dias Toffoli, DJe 2.2.2015.

31 "ADMINISTRATIVO. CONCURSO PÚBLICO. MÉDICO PERITO DO INSS. POSSE NO CARGO. ANTECEDENTES CRIMINAIS. PRINCÍPIO DA PRESUNÇÃO DE INOCÊNCIA E SUPREMACIA DO INTERESSE PÚBLICO. PONDERAÇÃO. [...] Hipótese em que o interesse coletivo deve prevalecer, buscando evitar o ingresso no serviço público daqueles que não apresentem passado absolutamente hígido. O princípio da presunção de inocência deve ser
} 


\section{I.2.3. Regra de juízo}

Já a regra de juízo traz a terceira dimensão da presunção de inocência, e incumbe à acusação os ônus de fundamentação e de comprovação de suas alegações. Para a condenação penal, o órgão acusador tem a incumbência de produzir a prova inconteste do fato constitutivo de direito, que no caso é o direito do Estado de concretizar sua pretensão punitiva, de forma a convencer plenamente o juiz no decurso da instrução criminal.

Desde logo, relevante se faz a constatação de que a mera prática de uma conduta formalmente típica não enseja condenação criminal. A tipicidade formal é o perfeito encaixe entre conduta e tipo penal, de maneira que, para que haja punibilidade, é necessária também a comprovação de tipicidade material, caracterizada por uma relevante turbação ao meio social que justifique a intervenção do meio penal, uma lesão significativa a bem jurídico.

Imputar a quem alega o ônus de comprovar é uma regra que afeta diretamente o julgamento da causa eis que, diante da incerteza que pode advir da reconstituição dos fatos realizada no processo, o ônus de afastar quaisquer dúvidas deve recair sobre o órgão acusatório, resguardando-se ao réu seu estado de inocência e liberdade, também com fulcro no princípio in dubio pro reo et contra civitatem.

Neste diapasão, a inversão do ônus argumentativo e de prova é vedada, visto que o réu não precisa provar sua inocência quando ela é presumida, e somente pode ser afastada havendo prova inconteste em contrário.

ponderado com os demais princípios constitucionais, prevalecendo, no caso, a supremacia do interesse público, uma vez que o impetrante responde ação penal por ter incorrido, em princípio, em crime de peculato por 19 (dezenove) vezes. Apelação a que se nega provimento“. (TRF-4, AC 5002858-75.2012.4.04.7007/PR, Rel. Juiz Federal Convocado Sérgio Garcia, 4 a Turma, julgado em 23/02/2016) 
Equivocado seria, portanto, exigir da defesa a produção de uma prova negativa dos fatos, ou a comprovação da existência de causa excludente de antijuridicidade ou de culpabilidade.

Para tais fins, Silva Jardim salienta o caráter indivisível do crime, que reafirma a necessidade de o órgão acusador comprovar o cometimento de crime em todos os seus elementos, quais sejam a tipicidade, ilicitude e culpabilidade. ${ }^{32}$ Isto é dizer que não basta comprovar uma conduta meramente típica, devendo se alcançar uma conduta legalmente qualificada como crime em sua totalidade.

Não é dizer que caberia ao órgão acusador o ônus de produzir prova negativa, ao ter de apontar de maneira expressa a ausência de quaisquer excludentes. É que, decerto, somente a acusação tem o dever de apresentar alegações no processo penal, limitando-se a defesa à mera negação dos fatos narrados, porque não obrigada a produzir provas.

O artigo 395, I e III, do CPP prevê, dentre as hipóteses de rejeição da denúncia: (i) a inépcia formal, que consiste em um defeito de forma que impede o exercício da ampla defesa, como é o caso da descrição insuficiente ou mal delineada dos fatos imputados - acusação descumpre o dever de fundamentação; (ii) a inépcia material, que ocorre quando não há elementos mínimos que comprovem a ocorrência do delito (fumus boni iuris), ou quando se imputa uma conduta que não é criminosa - acusação descumpre o dever de comprovação. ${ }^{33}$

\footnotetext{
32 JARDIM, Afrânio Silva. O princípio da indivisibilidade e a Ação Penal Pública Condicionada. Justitia, São Paulo, 51 (146), abr./jun., 1989. Disponível em <https://bdjur.stj.jus.br/jspui/bitstream/2011/22973/principio_indivisibilidade_acao_penal.pdf> ${ }^{33}$ Artigo 395, CPP. “A denúncia ou queixa será rejeitada quando: I - for manifestamente inepta; II faltar pressuposto processual ou condição para o exercício da ação penal; ou III - faltar justa causa para o exercício da ação penal".
} 
O conhecimento do conteúdo da acusação é essencial para um processo penal justo. A acusação deve ser feita de forma clara, com fatos certos, determinados e circunstanciados para garantir ampla defesa, nos termos do artigo 41 do CPP, sob pena de ser declarada inepta. ${ }^{34}$ Assim, garante-se a ampla defesa do acusado, na medida em que se obtém o conhecimento pleno sobre as alegações de fato e de direito que lhe foram imputadas.

Importante ressaltar que a acusação penal não pode ser genérica, visto que a matéria penal é admitida de forma individual e concreta, atentando para revelações que podem ser incomuns em relação a um processo passado de natureza semelhante. Inclusive, a ausência de causas excludentes de antijuricidade e de culpabilidade deve ser explicitamente abordada quando do oferecimento da denúncia eis que, do contrário, a inicial também seria manifestamente inepta.

Fato é que se a acusação, com todo o aparato investigativo de que dispõe, não consegue descrever satisfatoriamente os fatos e as imputações, nem trazer ao juízo indícios mínimos de autoria e de materialidade, há que se pedir o arquivamento da notícia de fato ou de inquérito, até mesmo à luz do princípio da eficiência que rege a atuação dos agentes públicos, a teor do artigo 37 da CRFB. ${ }^{35}$

Outra ressalva pertinente é que o réu se defende dos fatos narrados na denúncia, e não da capitulação legal da conduta praticada. É tanto que o

\footnotetext{
${ }^{34}$ Artigo 41, CPP. “ A denúncia ou queixa conterá a exposição do fato criminoso, com todas as suas circunstâncias, a qualificação do acusado ou esclarecimentos pelos quais se possa identificá-lo, a classificação do crime e, quando necessário, o rol das testemunhas".

${ }^{35}$ Insta ressaltar a gravidade da opção do órgão acusatório de oferecer a denúncia, eis que, nos termos do artigo 42 do CPP, veda-se ao Ministério Público a desistência da ação penal.

Artigo 37, CRFB. "A administração pública direta e indireta de qualquer dos Poderes da União, dos Estados, do Distrito Federal e dos Municípios obedecerá aos princípios de legalidade, impessoalidade, moralidade, publicidade e eficiência e, também, ao seguinte".
} 
artigo 383 do CPP dispõe sobre o instituto da emendatio libelli, por meio do qual se faculta ao juiz atribuir definição jurídica diversa sobre os fatos narrados na exordial acusatória, ainda que importe na aplicação de uma pena mais grave. ${ }^{36}$

Se o juízo criminal afirmar genericamente a inexistência de tais excludentes, ocorre clara desobediência ao dever de motivação, acarretando na nulidade da sentença que assim dispuser. Excetua-se, então, apenas a oportunidade na qual o réu opõe exceções substanciais que, nesse caso, devem ser provadas por ele.

O princípio in dubio pro reo reverbera tanto na análise do conteúdo probatório do processo quanto na interpretação da lei penal ou processual penal, de tal forma que se deve optar necessariamente pela interpretação menos gravosa ao réu, se mais de uma for possível no caso. É tanto que o artigo 386 do CPP elenca, dentre as hipóteses de absolvição, a insuficiência de provas e a existência de fundada dúvida. ${ }^{37}$

Assim, o juiz deve absolver o acusado quando restarem dúvidas sobre a autoria e materialidade de um crime, o que pode se caracterizar quando as provas acusatórias não forem suficientes para afastar uma tese defensiva verossímil, ainda que o magistrado não tenha se convencido por ela.

\footnotetext{
${ }^{36}$ Artigo 383, CPP. “O juiz, sem modificar a descrição do fato contida na denúncia ou queixa, poderá atribuir-lhe definição jurídica diversa, ainda que, em conseqüência, tenha de aplicar pena mais grave".

${ }^{37}$ Artigo 386, CPP. "O juiz absolverá o réu, mencionando a causa na parte dispositiva, desde que reconheça: I - estar provada a inexistência do fato; II - não haver prova da existência do fato; III - não constituir o fato infração penal; IV - estar provado que o réu não concorreu para a infração penal; V - não existir prova de ter o réu concorrido para a infração penal; VI - existirem circunstâncias que excluam o crime ou isentem o réu de pena (arts. 20,21, 22, 23, 26 e $\S 1^{\circ}$ do art. 28, todos do Código Penal), ou mesmo se houver fundada dúvida sobre sua existência; VII - não existir prova suficiente para a condenação."
} 
Da regra de distribuição do ônus da prova à luz da presunção de inocência, também se extrai a garantia de não autoincriminação - nemo tenetur se detegere -, vedando que se obrigue o acusado a confessar ou a colaborar na produção de prova contra si mesmo.

Em função desse preceito é que o artigo $5^{\circ}$, LXIII, da CRFB prevê o direito ao silêncio no rol de direitos fundamentais, ${ }^{38}$ e que o artigo $8^{\circ}, 2, \mathrm{~g}$, do Pacto de San José da Costa Rica confere à pessoa acusada o “direito de não ser obrigada a depor contra si mesma, nem a declarar-se culpada “ ${ }^{39}$

Em razão desse dispositivo, foi editada a Lei $n^{\circ} 10.792 / 2003$ para alterar a redação do artigo 186 do CPP, que passou a dispor tanto que o juiz deve informar ao acusado sobre seu direito ao silêncio, quanto que o silêncio deste não importa em confissão, nem pode ser interpretado de maneira prejudicial. $^{40}$

Segundo Aury Lopes Jr., a autoridade policial ou judicial devem cientificar o acusado, previamente, sobre seu direito ao silêncio, sob pena de nulidade do ato praticado em violação à norma constitucional. ${ }^{41}$ Rogério Sanches, por sua vez, aponta que os tribunais superiores vêm consolidando entendimento de que se trata de uma nulidade relativa, cujo reconhecimento depende da demonstração de prejuízo à defesa. ${ }^{42}$

\footnotetext{
${ }^{38}$ Artigo 5 $5^{\circ}$, LXIII. “[...] o preso será informado de seus direitos, entre os quais o de permanecer calado, sendo-lhe assegurada a assistência da família e de advogado“.

${ }^{39}$ Artigo $8^{\circ}, 2$, g, CADH. " Toda pessoa acusada de delito tem direito a que se presuma sua inocência enquanto não se comprove legalmente sua culpa. Durante o processo, toda pessoa tem direito, em plena igualdade, às seguintes garantias mínimas: [...] g. direito de não ser obrigado a depor contra si mesma, nem a declarar-se culpada".

${ }^{40}$ Artigo 186, CPP. "Depois de devidamente qualificado e cientificado do inteiro teor da acusação, o acusado será informado pelo juiz, antes de iniciar o interrogatório, do seu direito de permanecer calado e de não responder perguntas que lhe forem formuladas. Parágrafo único. O silêncio, que não importará em confissão, não poderá ser interpretado em prejuízo da defesa“.

${ }^{41}$ LOPES JR., Aury. Direito Processual Penal - 13 ed. - São Paulo: Saraiva, 2016, p. 104.

${ }^{42}$ CUNHA, Rogério Sanches. Interrogatório: Informação sobre o direito ao silêncio e nulidade. 2017. Disponível em: <http://meusitejuridico.com.br/2017/06/29/interrogatorio-informacao-sobreo-direito-ao-silencio-e-nulidade/>
} 
Entretanto, permanece inalterado o artigo 198 do CPP, que permite que o juiz tome o silêncio do acusado como elemento para formação de seu convencimento. ${ }^{43}$ Ou seja: contanto que aliado a outros elementos de prova, o dispositivo admitiria que o silêncio do acusado possa contribuir para sua própria condenação. Ana Paula de Castro sustenta que o artigo não teria sido recepcionado, em razão do direito constitucional ao silêncio, a menos que o convencimento seja aplicado em benefício do réu. ${ }^{44}$

Note-se que a garantia da ampla defesa garante ao acusado o livre arbítrio sobre a produção do seu interrogatório. $\mathrm{O}$ direito ao silêncio pode ser exercido de forma parcial e, portanto, o acusado pode optar por responder algumas perguntas, mas não outras que reputar prejudiciais, conforme instruído ou não por seu advogado, e também pode escolher responder às perguntas apenas do seu advogado, ou não responder às perguntas de alguma das autoridades presentes.

Para mais, se a pessoa acusada não possui o dever, mas apenas a faculdade de se manifestar pessoalmente em sua defesa, extrai-se que o interrogatório deveria ser realizado apenas quando requerido por declaração espontânea. Isso porque a verdade apenas vive em um ambiente de livre arbítrio, e não por uma imposição do juízo. Verificada a voluntariedade, admite-se que o acusado traga em sua verdade elementos prejudiciais a si, ou confesse.

\footnotetext{
${ }^{43}$ Artigo 198, CPP. "O silêncio do acusado não importará confissão, mas poderá constituir elemento para a formação do convencimento do juiz".

${ }^{44}$ CASTRO, Ana Paula Soares da Silva de. O Processo Penal é um direito constitucional aplicado?. Âmbito Jurídico, Rio Grande, XII, n. 66, jul 2009. Disponível em: <http://www.ambitojuridico.com.br/site/index.php?n_link=revista_artigos_leitura\&artigo_id=6382>. Acesso em nov 2018.
} 
Por isso mesmo, o artigo 185 do CPP, que disciplina o procedimento do interrogatório, não obriga o acusado a comparecer perante a autoridade judiciária, isto é, o acusado não pode nem ao menos ser constrangido a se apresentar perante o juiz para, então, se recusar a prestar sua versão dos fatos. $^{45}$

Um importante requisito para apurar a voluntariedade das declarações prestadas é a consciência do acusado. Embora o testemunho indireto não seja, a princípio, vedado pelo sistema processual penal brasileiro, não se admite que a utilização, como elemento de prova, de depoimentos de corréus, policiais ou testemunhas reproduzindo declarações informais do acusado que o prejudiquem. Para que as declarações dadas informalmente obtivessem validade processual, o acusado precisaria então reafirmá-las perante o juízo criminal.

A garantia de não autoincriminação resguarda não apenas as palavras do acusado, como seu próprio corpo. É que, com o desenvolvimento das ciências biológicas e da tecnologia, foram desenvolvidos novos métodos para se investigar a autoria de um crime, tanto por meio de provas não invasivas, a partir de vestígios do corpo do acusado na cena do crime, como impressões digitais e fios de cabelo, ou de provas invasivas, que necessitam do próprio corpo do acusado, como exames de sangue.

Evinis Talon explica que o CPP ainda não disciplina o dever de o réu colaborar ou não com a realização dessas provas, mas que o entendimento jurisprudencial do STJ é no sentido de que o Estado não é impedido de utilizar, para a realização de perícia, materiais genéticos encontrados em

\footnotetext{
${ }^{45}$ Artigo 185, CPP. "O acusado que comparecer perante a autoridade judiciária, no curso do processo penal, será qualificado e interrogado na presença de seu defensor, constituído ou nomeado".
} 
materiais descartados pelo acusado, já que o exame de DNA seria realizado sem violência moral ou física que configurasse constrangimento ilegal. ${ }^{46}$

Entretanto, a Lei 12.654/2012 instituiu a coleta de material biológico dos condenados por crime dolosos com grave violência contra pessoa, por meio de técnica adequada e indolor para fins de formação do perfil genético, como forma de identificação criminal considerada essencial às investigações, mediante representação ou por determinação judicial de ofício.

Grazinoli Garrido narra que os defensores da constitucionalidade da lei argumentam de que a tipagem genética não pode ser considerada autoincriminação, na medida em que ocorre após a condenação e, assim, não serve de prova no processo. Ele ressalta que, todavia, os dados inseridos no banco podem ser utilizados para solucionar crimes anteriores à condenação inclusos no sistema. ${ }^{47}$

Rogério Romano tece pertinentes críticas à lei de tipagem genética para fins de identificação criminal, in verbis: ${ }^{48}$

\begin{abstract}
"Lanço a minha suspeita, o meu receio, de que o armazenamento de dados genéticos, em um banco destinado à identificação de indivíduos, possa favorecer à discriminação, sobretudo quando pode levar alguém a ser discriminado no mercado de trabalho, mercê da indicação de doenças ou predisposição para elas, a seleção a determinados cargos ou funções no serviço público. Considero, pois, tal banco de dados uma afronta ao direito à intimidade previsto no artigo 5o, X, da Constituição Federal. Observa-se o perigo de disseminação de informações com relação ao genoma do investigado. Tal prova deve ser protegida pelo sigilo, e se for usada, fora desse parâmetro, é caso de prova ilícita. [...] É o ressurgimento perigoso, no
\end{abstract}

\footnotetext{
${ }^{46}$ TALON, Evinis. Provas invasivas e não invasivas no processo penal. 2018. Disponível em: <http://evinistalon.com/provas-invasivas-e-nao-invasivas-no-processo-penal/>. Acesso em nov. 2018.

${ }^{47}$ GRAZINOLI GARRIDO, Rodrigo; LEAL RODRIGUES, Eduardo. O Banco de Perfis Genéticos Brasileiro Três Anos após a Lei $n^{\circ} 12.654$. Rev. Bioética y Derecho, Barcelona, n. 35, p. 94-107, 2015. Disponível em: <http://scielo.isciii.es/scielo.php?script=sci_arttext\&pid=S1886$58872015000300009 \& \operatorname{lng}=\mathrm{es} \& \mathrm{nrm}=\mathrm{iso}>$. Acesso em nov. 2018. ${ }^{48}$ ROMANO, R.T. Identificação Criminal pelo DNA: Uma Experiência Lombrosiana. Disponível em: <https://www.jfrn.gov.br/institucional/bibliotecaold/doutrina/Doutrina305-identificacao-criminal-pelo-dna.pdf >. Acesso em nov. 2018.
} 
direito brasileiro, da escola de Lombroso, do direito penal do autor. Tal, num Estado Democrático de Direito, deve ser objeto de diversas limitações. Além disso, a pirotecnia sensacionalista encontra nesse banco de dados um forte aliado. Vamos estabelecer um banco de criminosos natos. Isso em pleno século XXI, num Estado Democrático de Direito. [...] Referendar um cadastro genético nacional de condenados em crimes graves é trilhar o caminho do Estado da Segurança Pública, em oposição ao Estado de Direito e das liberdades públicas. Assim se inserindo, volveríamos, de forma condenável, ao sistema inquisitivo, da supremacia do interesse público, em que a pessoa, ao invés de estar em situação de inocência, passaria ao estado de suspeição."

Segundo jurisprudência dos tribunais superiores, o direito ao silêncio também socorre à testemunha que possa se autoincriminar por meio do depoimento, e ao advogado que assim a instrua, sob pena de anulação da sentença, e de proferimento de uma nova com o conjunto das provas restantes. $^{49}$

Em que pese seu dever de falar a verdade, é certo que, nessa situação, a testemunha ostenta qualidade de potencial acusado, devendo dispor das mesmas prerrogativas que ele - seja a de permanecer calado, seja a de mentir.

Não haveria que se falar em crime de falso testemunho, ${ }^{50}$ de um lado porque não existiria dolo de se furtar à administração da justiça, nem de prejudicar quem quer que seja, e de outro porque a testemunha está respaldada pela hipótese de excludente de ilicitude prevista no artigo 23, III, do CP, qual seja o exercício regular de seu direito fundamental ao silêncio. ${ }^{51}$

Por fim, insta ressaltar o recente julgamento das ADPFs nº 395 e 444 pelo Supremo Tribunal Federal, em junho de 2018, no qual se proibiu a condução coercitiva de investigados e réus para depoimento, até então do-direito-ao-silêncio-torna-il\%C3\% ADcito-depoimento-de-testemunha>. Acesso em nov. 2018. ${ }^{50}$ Artigo 342, CP. "Fazer afirmação falsa, ou negar ou calar a verdade como testemunha, perito, contador, tradutor ou intérprete em processo judicial, ou administrativo, inquérito policial, ou em juízo arbitral: Pena - reclusão, de 2 (dois) a 4 (quatro) anos, e multa".

${ }^{51}$ Artigo 23, CP. "Não há crime quando o agente pratica o fato: I - em estado de necessidade; II em legítima defesa; III - em estrito cumprimento de dever legal ou no exercício regular de direito". 
prevista no artigo 260 do CPP, em razão da liberdade de locomoção e da garantia de não-autoincriminação e do devido processo legal, decorrentes da presunção de inocência.

Espera-se, assim, ter trazido material suficiente, ainda que não exaustivo, sobre a importância da presunção de inocência enquanto princípio fundamental do processo penal, e seus desdobramentos, para então passar à disciplina do direito penal econômico, e a alguns pontos controvertidos de maior interesse para os fins deste trabalho. 


\section{Dos crimes econômicos}

\section{II.1. Construção criminológica}

Cumpre esclarecer que se afigura prescindível tratar sobre os antecedentes do direito penal econômico que remontam à Antiguidade, em que pese existentes, em razão do descontinuismo histórico da matéria, que só foi revisitada efetivamente na Idade Moderna, sob um prisma diferente..$^{52}$

A matriz do direito penal econômico moderno foi o Manifesto Comunista de Marx e Engels de 1848, em que foi feita uma análise crítica do direito penal, na medida em que não existiria criminalidade, mas um processo de criminalização de determinadas classes sociais.

Juarez Cirino explica que, para os autores, o significado político do direito penal seria de instituição de garantia e de reprodução da estrutura de classes da sociedade, da desigualdade, da exploração e da opressão das classes sociais subalternas pelas classes sociais hegemônicas. ${ }^{53}$

Naquele momento histórico, ainda não se falava em direito econômico, porque os países da Europa ocidental experimentavam, predominantemente, a política de livre mercado. Não havendo intervenção estatal, também não havia regulamentação, o que passou a dar ensejo ao abuso do poder econômico dos detentores dos meios de produção, levando às grandes crises econômicas internacionais.

\footnotetext{
${ }^{52}$ Desde a Grécia e Roma antigas, e o Antigo Testamento, existiram disposições legais punitivas para os crimes realizados no âmbito do comércio. Contudo, é notável o desconstituismo histórico da matéria que, apesar de se encontrar de forma breve nas Ordenações Filipinas, Livro V, Título LIX, só foi revisitada efetivamente na Idade Moderna, com novos interesses que se visa proteger, conforme se demonstrará a seguir.

${ }^{53}$ SANTOS, Juarez Cirino dos. Direito penal: parte geral. 3. ed. Curitiba: ICPC; Lumen Júris, 2008, p. 8 .
} 
A criminologia despontou na Europa em 1876, a partir da publicação da obra O Homem Delinquente de Cesare Lombroso, como ciência auxiliar do direito penal que busca justificar o poder punitivo. Para tanto, realiza-se a etiologia do comportamento criminal com base no perfil físico e psicológico do criminoso, este elaborado por meio de métodos científicos. É que, nesse estágio inicial, a antropologia criminal concebe a criminalidade enquanto doença, loucura moral, o que tornaria possível diagnosticá-la.

Em 1912, Émile Durkheim teceu em sua obra Lições de Sociologia considerações sobre a criminologia, no sentido de que o crime não seria de todo mal, pecado ou doença, porque serviria para solidificar a pauta moral na consciência coletiva, mas com a seguinte ressalva: à medida em que se confere menor importância à solidariedade nas sociedades, haveria um cenário de anomia propenso ao cometimento de crimes, porque faltaria aos cidadãos a internalização dos pretendidos valores morais.

O viés determinista também esteve presente, nos anos 1920, nos estudos de sociologia criminal da Escola de Chicago. Porém, ao contrário do determinismo biopsicológico de Lombroso, passou-se a estudar a criminalidade sob o prisma do determinismo social. Para tanto, foram analisadas zonas periféricas do espaço urbano, visando comprovar a influência na degradação moral dos seus habitantes.

Nos anos 1930, Robert Merton cunhou a criminologia estruturalfuncionalista, que explicava os crimes como sendo os meios de acesso ilegítimo adotados pelos sujeitos que não dispõem dos recursos necessários, para assim atingir os fins culturais designados como signos de status social. 
Para o autor, a criminalidade reside na inconformidade com os meios legítimos disponíveis para o acesso aos valores culturais. ${ }^{54}$

A partir da falência do modelo econômico liberal, com a crise dos anos 1930, ganhou força a teoria econômica de John Maynard Keynes, oposta às concepções liberais, segundo a qual deveria ocorrer uma verdadeira reforma do capitalismo, de modo que o Estado se tornaria o agente indispensável de controle e fomento da economia, com o fito de conduzir um sistema de pleno emprego. O direito econômico surge, então, para elaborar e estudar as regras criadas para que o Estado pudesse reprimir os abusos do poder econômico.

Em 1940, Edwin Sutherland observou que, até então, as teorias criminológicas não procuravam explicar a criminalidade econômica, o que apenas colaborava para a manutenção de sua impunidade, e inaugurou o estudo da criminalidade econômica com sua obra Crime de Colarinho Branco, em que lançou as bases para a punição efetiva de condutas relacionadas ao abuso de poder econômico.

Para quebrar os paradigmas impostos pelas correntes criminológicas da época, Sutherland apontou a falha metodológica dos estudos criminológicos, que se afiguravam tendenciosos porque restringiam seu objeto aos criminosos que eram efetivamente presos e condenados, que são

\footnotetext{
${ }^{54}$ Seriam cinco as possíveis posturas adotadas pelo indivíduo não detentor dos recursos necessários para se utilizar dos meios legítimos para atingir os fins culturalmente reconhecidos: (i) conformidade, (ii) inovação, (iii) ritualismo, (iv) apatia e (v) rebelião. O conformado é aquele que, mesmo sabendo das limitações para utilização dos meios legítimos, aceita sua incapacidade de atingir os fins culturais, e não transgride à lei. O inovador é aquele que, inconformado com a sua incapacidade de atingir os fins culturais, busca outras alternativas para chegar aos seus objetivos, admitindo-se inclusive a transgressão à lei. $\mathrm{O}$ ritualista abre mão dos meios culturais mas não quer ou não tem coragem de ir contra as leis, porque sente descrença, e não possui grandes aspirações. $O$ apático abre mão dos fins culturais e dos meios de acesso, então não comunga dos interesses sociais, mas na apatia poderia-se encontrar comportamentos criminosos. O rebelde abre mão dos fins culturais, não concorda com os meios de acesso, e além disso visa modificar a relação de acesso aos meios, de modo que diante de determinada ordem pode vir a cometer crimes.
} 
em maior parte pertencentes às classes mais baixas e marginalizadas da sociedade.

Segundo o autor, esse filtro mascarava tanto a cifra oculta da criminalidade, composta pelos agentes comuns cujos crimes não foram descobertos, solucionados ou punidos, ${ }^{55}$ quanto a cifra dourada da criminalidade, composta pelos indivíduos de alta respeitabilidade social no exercício de seus negócios, cujos crimes são ainda mais subnotificados, tanto pela natureza dos crimes cometidos, quanto pelos privilégios sociais conferidos a esses indivíduos.

Nessa esteira, dois fatores contribuiriam para a impunidade: (i) pessoas de classe socioeconômica mais alta possuem recursos para contratar advogados habilidosos e para influenciar a administração da justiça em seu favor de forma mais efetiva do que as demais; (ii) o delito econômico não só não costuma ser descoberto como, uma vez sendo, não é considerado efetivamente como crime pelo Estado, por conta dos procedimentos administrativos (e, portanto, não estigmatizantes) usados para lidar com os infratores. ${ }^{56}$

Sutherland também concebeu a teoria da associação diferencial, segundo a qual a criminalidade se herdaria geneticamente como pretendia a

\footnotetext{
${ }^{55}$ Enquanto a criminalização primária se dá pela atividade legislativa, a criminalização secundária ocorre no âmbito fático, pelos órgãos executivos. A cifra oculta se reside na criminalização secundária, e possui diversas razões, notadamente a falta de interesse político dos órgãos investigativos e persecutórios. Zaffaroni et al. explicam essa seletividade: “[...] as agências de criminalização secundária, tendo em vista sua escassa capacidade perante a imensidão do programa que discursivamente lhes é recomendado, devem optar pela inatividade ou pela seleção. Como a inatividade acarretaria seu desaparecimento, elas seguem. regra de toda a burocracia e procedem à seleção. Este poder corresponde fundamentalmente às agências policiais. De qualquer maneira, as agências policiais não selecionam segundo seu critério exclusivo, mas sua atividade neste sentido é também condicionada pelo poder de outras agências: as de comunicação social, as agências políticas etc. [...] Em razão da escassíssima capacidade operacional das agências executivas, a impunidade é sempre a regra e a criminalização secundária, a exceção [...]". ZAFFARONI, Eugenio Raúl; BATISTA, Nilo; ALAGIA, Alejandro; SLOKAR, Alejandro, Direito Penal Brasileiro: primeiro volume. Rio de Janeiro: Revan, 2003, $4^{\text {a }}$ edição, 2011. $2^{\text {a }}$ reimpressão, 2015.

${ }^{56}$ SUTHERLAND, Edwin H. Crime de colarinho branco: versão sem cortes; tradução: Clécio Lemos. Rio de Janeiro: Revan, 2015, $1^{\text {a }}$ reimpressão, setembro de 2016, pp. 33-34.
} 
antropologia criminal, nem seria produto de zonas degradadas ou da dificuldade de acesso aos fins da cultura geral, mas sim aprendida no contexto de subculturas que justificariam entre si a prática de condutas criminosas - grupos de delinquentes.

Sustentando que a criminalidade ocorreria em razão da associação ou não do indivíduo a determinados grupos que justificam o desvio criminal, pôde-se conceber que um sujeito bem sucedido e respeitado cometer crimes, como por exemplo os homens de negócios que desviam das regras de mercado para otimizar seus lucros.

Em que pese a grande inovação no pensamento de Sutherland, observa-se demasiada subjetividade em sua conceituação do crime econômico, que acarreta em algumas imprecisões. A um, limitar a figura do agente criminoso às pessoas de alta classe impediria que pessoas de classe média, como um comerciante, pudessem cometer crime contra a ordem econômica e, a dois, nem todo crime praticado no âmbito dos negócios seria necessariamente um crime contra a ordem econômica.

A três, ao centrar sua noção jurídica de crime econômico no agente criminoso, e não no bem jurídico ordem econômica, Sutherland acaba por professar um direito penal do autor que é perigosamente antidemocrático, porque esvazia a presunção de inocência enquanto valor democrático que deve ser respeitado pelos demais, de ver o acusado como uma pessoa digna de direitos, e não como um mal a ser combatido.

Decerto, a faceta mais cruel do direito penal do autor é justamente o direito penal do inimigo, porque essa lógica leva à "caça às bruxas," ou seja, à inflação da opinião pública pelo fim da impunidade mediante a eleição de um inimigo comum, o que legitima o poder Judiciário a promover a relativização das garantias dos acusados. 
Foi em 1985 que Günther Jakobs apresentou a tese do direito penal do inimigo, sustentando a necessidade de criação de dois direitos penais. $\mathrm{O}$ primeiro seria destinado aos cidadãos, e disporia de um vasto aparato de garantias, enquanto o segundo visaria os não-cidadãos - inimigos, dispensando-lhes um tratamento penal diferenciado, que mitigasse suas garantias penais e processuais penais. ${ }^{57}$

Zaffaroni e Ferrajoli sustentam que o direito penal do inimigo não se compatibiliza com Estados Democráticos de Direito, em que os processos penais devem transcorrer de forma igualitária. Ivan Carlos da Silva ressalta, ainda, que essa tese é desumanizadora, e viola o próprio direito da pessoa de ser reconhecida como tal perante a lei, uma vez que "o conceito de pessoa não é um conceito de Estado, mas de um Direito inerente ao ser humano, que transcende a qualquer soberania."

Devido à contemporaneidade entre os autores, conta-se que Merton tentou compatibilizar sua concepção para abranger a criminalidade de colarinho branco. Passou, então, a afirmar que tais criminosos personificariam o contraste entre os fins culturais e os meios legítimos para o seu alcance, enquanto sujeitos que não interiorizaram as normas institucionais que determinam os meios legítimos. ${ }^{58}$

Para mais, em 1995, Hulsman compatibilizou as novas concepções à perspectiva marxista, ao denotar a existência de uma tendência bastante recente que questiona o conceito de delito enquanto realidade ontológica.

57 SILVA, Ivan Carlos da. $O$ direito penal do inimigo. Disponível em: <http://unisinos.br/blogs/ndh/2013/07/29/o-direito-penal-do-inimigo/>. Acesso em nov. 2018.

${ }^{58}$ CABETTE, Eduardo. Robert Merton e a criminalidade de colarinho branco: formulando uma hipótese de compatibilidade. Disponível em: <https://eduardocabette.jusbrasil.com.br/artigos/211599053/robert-merton-e-a-criminalidade-decolarinho-branco-formulando-uma-hipotese-de-compatibilidade>. Acesso em nov. 2018. 
Nessa lógica, se o direito positivado é o que estabelece o que é delito ou não, ele poderia ser manipulado para promover o processo de criminalização de certos grupos, e de impunidade de outros, como o da criminalidade de colarinho branco. ${ }^{59}$

\section{II.2. Construção jurídica}

Os crimes econômicos podem ser conceituados, de forma restrita, como aqueles cometidos contra a ordem econômica, sob a regulação jurídica do Estado. Heleno Cláudio Fragoso sustenta que o crime econômico é aquele cuja "objetividade jurídica reside na ordem econômica, ou seja, em beminteresse supraindividual, que se expressa no funcionamento regular do processo econômico de produção, circulação e consumo de riqueza". ${ }^{60}$

Já nesta primeira concepção, admite-se como crimes econômicos aqueles que atinjam sujeitos passivos secundários mas que, indiretamente, prejudiquem também a ordem econômica, como é o caso da propaganda enganosa que, em tese, atingiria apenas os consumidores, mas também abalaria a confiança na economia e no sistema de fornecimento de produtos e serviços.

Em outro piso, sob a concepção ampliativa, Hervé Boullanger entende os crimes econômicos como quaisquer crimes cometidos em face da ordem pública econômica, englobando assim os âmbitos econômico, social, financeiro, negocial e empresarial. ${ }^{61}$ Engloba-se assim os crimes que violem

\footnotetext{
${ }^{59}$ HULSMAN, Louk L. La criminología crítica y el concepto del delito. In: RAMÍREZ, Juan Bustos. Prevencion y teoria de la pena. Editorial Jurídica ConoSur Ltda, Santiago de Chile, 1995. Para demonstrar a tendência doutrinária, Hulsman faz as seguintes referências: Baratta, 1983; Hulsman y Bernat de Celis, 1982; Landreville, 1978; A. Normandeau, 1984.

${ }^{60}$ FRAGOSO, Heleno Cláudio. Direito penal econômico e direito penal dos negócios. Revista de Direito Penal e Criminologia, Rio de Janeiro, n. 33, jan.-jun. 1982, pp. 122-129.

${ }^{61}$ BOULANGER, Hervé. La criminalité économique en Europe. Paris: Presses Universitaires de France, 2002. apud SANTOS, Juliana Pinheiro. Questão conceitual: Crimes de colarinho-branco ou crimes econômicos? Disponível em: <http://www.ambito-
} 
a funcionalidade estrutural do sistema econômico, ainda que de maneira indireta, por meio de pessoa jurídica privada.

Nesse diapasão, Garcia Martín explica que a atividade econômica e a atividade empresarial se imbricam mutuamente, porque esta constitui: ${ }^{62}$

"...] a fonte principal do domínio material sobre todo tipo de bens jurídicos envolvidos na atividade econômica, isto é, não é só sobre os especificamente econômicos como a livre concorrência, e meio-ambientais, mas também sobre outros de diferente natureza que aparecem com frequência igualmente envolvidos de um modo típico na prática de atividade econômico-empresarial".

Por sua vez, Regis Prado expõe que a abrangência do conceito de ordem econômica em relação às ordens tributária, financeira, monetária e a relação de consumo, é decorrente da busca pela tutela dos bens jurídicos supraindividuais, genericamente considerados, o que por si só não exclui a proteção de interesses individuais.

O autor ressalta, ainda, que o poder econômico é uma realidade social e, em si, não é reprovável, mas apenas quando viola os preceitos do mercado: 63

"O exercício do poder econômico que não tenha e não possa ter o efeito de dominância de mercado, de eliminação da concorrência ou aumento arbitrário de lucros não é considerado abusivo e, por conseguinte, não é objeto de repressão legal. Somente quando a própria competição está em risco, configurando exercício abusivo, é que há a repressão".

Para Marcello Benevides, seriam considerados hoje, portanto, os crimes contra a ordem econômica, os crimes contra a ordem tributária, os

juridico.com.br/site/index.php?n_link=revista_artigos_leitura\&artigo_id=9179>. Acesso em nov. 2018.

62 GRACIA MARTÍN, L. Prolegómenos para la lucha por la modernización y expansión del Derecho Penal y para la critica del discurso de resistencia, p. 84. apud PRADO, Luiz Regis. Direito penal econômico - 7 ed. rev. e atual. - São Paulo: Editora Revista dos Tribunais. 2016, p. 42.

${ }^{63}$ PRADO, Luiz Regis. Direito penal econômico - 7 ed. rev. e atual. - São Paulo: Editora Revista dos Tribunais. 2016, pp. 42-48. 
crimes falimentares, os crimes contra a administração pública, os crimes contra a organização do trabalho, e a lavagem de dinheiro. ${ }^{64}$

Em que pese a amplitude da conceituação, que inviabiliza um recorte da disciplina, não se pode deixar de mencionar a concepção de Edwin Sutherland, pai do direito penal econômico, de que o "crime de colarinho branco pode ser definido aproximadamente como um crime cometido por uma pessoa de respeitabilidade e alto status social no curso de sua atividade. ${ }^{65}$

Por sua vez, o direito penal econômico, em sentido estrito, é a disciplina que se refere a fatos que lesam ou expõem a perigo determinada ordem econômica. Para Fragoso, consiste no ramo do direito penal que tutela a funcionalidade da ordem econômica e do sistema financeiro, ${ }^{66}$ que se rege pela confiança.

Decerto, a confiança permeia a ordem econômica em diversos aspectos: é a confiança na segurança da instituição bancária que leva o trabalhador a depositar nela os seus proventos; é a confiança no sistema financeiro que atrai o investimento dos empresários; é a confiança nos padrões de qualidade que incentiva o consumidor a adquirir produtos; e é a confiança na boa gestão da Administração Pública que motiva o cidadão a comprar títulos públicos.

\footnotetext{
${ }^{64}$ BENEVIDES, Marcelo. Direito penal econômico trata de quais crimes? Disponível em: $<\mathrm{http}: / /$ marcellobenevides.com/direito-penal-economico-crimes/>. Acesso em nov. 2018.

${ }^{65}$ SUTHERLAND, Edwin H. Crime de colarinho branco: versão sem cortes; tradução: Clécio Lemos. Rio de Janeiro: Revan, 2015, $1^{\text {a }}$ reimpressão, setembro de 2016, pp. 33-34.

${ }^{66} \mathrm{O}$ sistema financeiro nacional consiste no "conjunto de leis que dispõe sobre a política e as instituições monetárias, bancárias; o mercado de capitais, o mercado de valores mobiliários e as sociedades por ações". NASCIMENTO, C. V. do. Curso de Direito Financeiro. apud PRADO, Luiz Regis. Direito penal econômico - 7 ed. rev. e atual. - São Paulo: Editora Revista dos Tribunais. 2016, pp. 182-183. Para Regis Prado, trata-se de "bem jurídico de natureza macrossomia ou transindividual, de cunho institucional ou coletivo, salvo exceções".
} 
Enquanto isso, na linha ampliativa, o direito penal econômico reúne o conjunto de normas jurídico-penais que protegem a ordem econômica, entendida como a regulação jurídica da produção, distribuição e consumo de bens e serviços, bem como as atividades adjacentes, de cunho empresarial e negocial que repercutam em direitos supraindividuais, como os consumeristas e os ambientais.

Ademais, o crime de lavagem de dinheiro consiste na inserção, em circuitos econômico-financeiros legais, de bens, direitos e valores provenientes de infração penal para ocultar ou dissimular sua natureza ilícita, o que também se enquadra como um crime de caráter eminentemente econômico, ${ }^{67}$ podendo atingir os sistemas negocial, financeiro, tributário, trabalhista, consumerista, etc.

Defende-se, ainda, que o crime de corrupção poderia ser considerado delito econômico. A um, eis que nos aspectos imediatos do crime, a motivação e consequências costumam ser de cunho econômico — de um lado, tem-se o agente público que aceita realizar atos de ofício viciados em troca de suborno e, de outro, o agente privado que pretende um usufruir ilicitamente de atos que beneficiem, de alguma forma, suas finanças e negócios.

A dois, porque ao menos o agente criminoso da corrupção satisfaz a concepção originária de Sutherland, de indivíduo de alta respeitabilidade e status social. Como bem explica Flávia Schilling: ${ }^{68}$

\footnotetext{
${ }^{67}$ CALLEGARI, André Luís. Imputação Objetiva. Lavagem de dinheiro e outros temas do Direito Penal. Porto Alegre: Livraria do Advogado, 2001. Vol. 1, p. 49.

${ }^{68}$ SCHILLING, Flávia. Corrupção: ilegalidade intolerável. Comissões parlamentares de inquérito e a luta contra a corrupção no Brasil (1980-1992). São Paulo: IBCCrim, 1999. 351p. apud BETTI, Francisco de Assis. Lei n. 8.429/92 - dos crimes de corrupção e suas consequências. Revista CEJ, V. 4 n. $10 \quad$ jan./abr. 2000. Disponível em: <http://www.cjf.jus.br/ojs2/index.php/revcej/article/viewArticle/253/523>. Acesso em nov. 2018.
} 
“corrupção é um conjunto variável de práticas que implica trocas entre quem detém poder decisório na política e na administração e quem detém poder econômico, visando à obtenção de vantagens ilícitas, ilegais ou ilegítimas para os indivíduos ou grupos envolvidos".

A três, porque existem aspectos mediatos do crime que são subnotificados, sendo certo que a corrupção em certas esferas do poder aflige não apenas a administração pública, como também, de forma endêmica, a ordem social e econômica. É que o poder público, enquanto garantidor de diversos serviços básicos como saúde, educação e segurança, ao se ver privado de parte de suas verbas, deixa de prestar esses serviços de forma plena. ${ }^{69}$

\title{
O impacto direto da corrupção na ordem econômica é bem verificado
} por Deltan Dallagnol, em sua análise sobre o Relatório Corrupção: custos econômicos e propostas de combate, elaborado pela Federação das Indústrias do Estado de São Paulo, em 2010:70

\begin{abstract}
"Segundo um estudo da Fiesp, a corrupção retarda o crescimento econômico de várias formas: reduz o incentivo ao investimento produtivo, pois é interpretada como mais uma taxa a ser paga, diminuindo a rentabilidade dos projetos; provoca queda nas receitas arrecadadas pelo governo, pois o desvio de dinheiro para atividades ilegais gera perdas orçamentárias e reduz a possibilidade de financiamento de gastos produtivos; diminui a eficácia dos recursos distribuídos pelo setor público, pois há enorme desperdício em atividades caçadoras de renda e improdutivas; gera ineficiência na administração pública, uma vez que os contratos licitados ganhos por empresas corruptoras podem comprometer a qualidade dos serviços e da infraestrutura pública, a má qualidade aumenta tanto a probabilidade de refazer o serviço como a frequência da manutenção, reduzindo a produtividade total da economia; distorce a composição dos gastos públicos, pois o governo pode
\end{abstract}

\footnotetext{
${ }^{69}$ Nas palavras de Deltan Dallagnol: "Quem mais sofre com essa situação são os pobres, que, ao contrário dos ricos, não podem arcar com os serviços essenciais que deixam de ser oferecidos pelo Estado. O rico consegue pagar alguns serviços do próprio bolso, enquanto o pobre paga mais frequentemente com a vida. Quem mais paga [pela corrupção] é o paciente que precisa urgentemente de tratamento contra o câncer, mas que não consegue porque os equipamentos do hospital não funcionam ou porque não há vagas. É a criança que almoça apenas biscoito e suco no colégio porque a verba da merenda escolar foi subtraída. São os 13 milhões de analfabetos - quase $10 \%$ dos brasileiros com mais de 15 anos - que não tiveram acesso ao ensino, o que nos dá um título nada invejável: o de oitava maior população analfabeta do mundo. É o cidadão comum que sofre a condenação mais cruel, enquanto os corruptos saem impunes."

${ }^{70}$ DALLAGNOL, Deltan. A luta contra a corrupção. Rio de Janeiro: Primeira Pessoa, 2017, pp. 44-45. O autor se refere ao Relatório Corrupção: custos econômicos e propostas de combate, elaborado pela Área de Competitividade da FIESP em março de 2010.
} 
favorecer projetos em que a lucratividade gerada pela corrupção seja maior, como consequência, ocorre deformação das policias sociais e de desenvolvimento."

Em países como o Brasil, que optam pelo modelo licitatório para contratações públicas, a corrupção se torna uma verdadeira prática de supressão da concorrência que, portanto, afeta a ordem econômica. ${ }^{71}$ É tão alto o grau de reprovabilidade da corrupção que, uma vez descoberta, gera uma crise de imprevisibilidade e risco nos negócios, em razão da perda de confiança dos investidores nas empresas e nos entes públicos envolvidos.

Dallagnol narra ainda que, em 2015, em meio à crise econômica e à Lava Jato, o Brasil perdeu o selo de bom pagador e o grau de investimento das três principais agências internacionais de classificação de risco. Ademais, as empresas envolvidas no escândalo tiveram sua imagem e seu crédito afetado, o que gerou um alto grau de endividamento e risco de falência das empresas, e aumentou o índice de desemprego.

No mesmo ano, a consultoria GO Associados realizou um estudo para estimar os efeitos derivados da Operação Lava-Jato na redução dos investimentos da Petrobras e do setor de construção de obras públicas, contabilizando as perdas no valor bruto da produção, nos empregos, nos salários e na geração de impostos. ${ }^{72}$

Já em 2018, Bráulio Borges, pesquisador do Instituto Brasileiro de Economia da FGV, atesta que os impactos da Operação Lava-Jato teriam sido

\footnotetext{
${ }^{71}$ Cabe ressaltar que a própria fraude à licitação já é considerada crime contra a ordem econômica, conforme será visto mais adiante.

${ }^{72}$ Somente a Operação Lava-Jato teria gerado (i) perdas de R \$ 142,6 bilhões na economia brasileira (o equivalente a 2,5\% do PIB brasileiro em 2015); (ii) redução de 1,9 milhões de empregos diretos e indiretos; (iii) queda de R $\$ 22,4$ bilhões em salários e (iv) diminuição de $\mathrm{R} \$ 9,4$ bilhões em arrecadação de impostos. ALVARENGA, Darlan. Impacto da Lava Jato no PIB pode passar de R\$ 140 bilhões, diz estudo. G1, São Paulo, 11/08/2015. Disponível em: <http://g1.globo.com/economia/noticia/2015/08/impacto-da-lava-jato-no-pib-pode-passar-de-r140-bilhoes-diz-estudo.html>. Acesso em nov. 2018.
} 
liquidamente negativos no curto prazo, mas serão bastante positivos no médio e longo prazos: ${ }^{73}$

\begin{abstract}
"[...] a L.J. poderia ser tratada como uma "onda reformista" (ao aumentar a eficiência do gasto público; gerar melhor alocação de recursos da economia; representar um salto positivo na governança das empresas privadas e estatais; dentre vários outros possíveis impactos positivos), mas com um custo de transição relativamente elevado (ao gerar instabilidade política, por envolver quase todo o establishment político; e por trazer o risco de uma crise sistêmica em caso de quebradeira geral de boa parte das empreiteiras brasileiras). Vale notar a ausência de uma institucionalidade bem definida para que as empresas envolvidas fechassem seus acordos de leniência - foi somente neste ano de 2018 que o primeiro acordo "completo", envolvendo AGU, CGU, MPF, PGR e TCU, foi fechado - contribuiu decisivamente para propagar e magnificar os riscos de uma crise sistêmica."
\end{abstract}

Para mais, há que se mencionar o delito de associação criminosa, que consiste na organização estruturada de agentes, com caráter estável e duradouro, visando à obtenção de vantagem ilícita de qualquer natureza, por meio da prática de infrações penais.

De acordo com o Relatório da Força-Tarefa contra o Crime Organizado da Comissão de Inquérito do Congresso Norte-americano de 1967, as grandes organizações criminosas se colocam como poder paralelo na sociedade, com o intuito de controlar vários campos de atividade econômica, e acumular lucros.

O crime de associação criminosa pode, portanto, caracterizar um crime econômico, (i) quando os agentes se associam para a prática de crimes contra a ordem econômica, e (ii) quando os agentes possuem como objetivo comum a obtenção de vantagem de natureza econômica.

\footnotetext{
${ }^{73}$ BORGES, Bráulio. Como a Lava-Jato afetou o PIB? Novas evidências para o debate. Disponível em: $\quad<$ https://blogdoibre.fgv.br/posts/como-lava-jato-afetou-o-pib-novas-evidencias-para-odebate>. Acesso em nov. 2018.
} 


\section{II.3. Disciplina legal}

No ordenamento jurídico republicano, os crimes econômicos foram mencionados pela primeira vez no artigo 122, alínea 17, da Constituição de 1937, que elencou os crimes contra a economia popular no rol de crimes contra o Estado brasileiro, cujo processo e julgamento deveria ser realizado perante tribunal especial. ${ }^{74} \mathrm{~A}$ regulamentação desses crimes se deu pela Lei de crimes contra a economia popular - Lei ${ }^{\circ} 1.521 / 1951$.

No Código Penal de 1940, já se trazia (i) os crimes contra a organização do trabalho, dentre os quais o constrangimento para paralisação de atividade econômica, (ii) os crimes contra a administração pública, como a corrupção ativa, e (iii) os crimes de descaminho e contrabando, que constituem crime contra a ordem tributária. ${ }^{75}$

Em seguida, na Constituição de 1946, se dispôs no artigo 148 sobre a repressão do abuso do poder econômico para a tutela da concorrência, o que deu ensejo à Lei 4.137/1962. Fábio Nusdeo ressalta dois aspectos dessa lei: (i) a tipificação de práticas de concorrência desleal e de aumento arbitrário de lucros; (ii) a criação do Conselho Administrativo de Defesa Econômica CADE. $^{76}$

\footnotetext{
${ }^{74}$ De fato, a Constituição de 1934 trazia a tutela da ordem econômica, mas sem mencionar o combate aos abusos do poder econômico, ou a tutela da concorrência. Foi com a Constituição de 1937 que se inaugurou um novo viés intervencionista, compatível com o momento histórico, que buscou dar efetividade ao modelo munindo-se, inclusive, da tipificação das condutas que configurassem abuso do poder econômico.

${ }^{75}$ Os crimes de contrabando e descaminho, então previstos em um único dispositivo, tiveram sua redação alterada pela Lei $n^{\circ}$ 13.008/2014, para separá-los em tipos penais autônomos. Em linhas básicas, diferenciam-se quanto ao objeto do crime: o descaminho se realiza pela importação, exportação, venda ou consumo produto estrangeiro sem recolhimento do imposto devido, enquanto o contrabando se dá pela importação, exportação, venda ou consumo de mercadoria proibida.

${ }^{76}$ NUSDEO, Fábio. Curso de economia: introdução ao direito econômico. apud PRADO, Luiz Regis. Direito penal econômico - 7 ed. rev. e atual. - São Paulo: Editora Revista dos Tribunais. 2016, p. 44.
} 
Sem maiores inovações, a Constituição de 1967 e a Emenda nº 1/1969 dispunham que a ordem econômica teria como fim realizar a justiça social, e para tanto consideravam como princípio dessa tutela a repressão do abuso do poder econômico, caracterizado pelo domínio dos mercados, a eliminação da concorrência e o aumento arbitrário dos lucros. ${ }^{77}$

Já na Constituição Federal de 1988, a tutela da ordem econômica se dá pelo artigo 170 e seguintes, estabelecendo-se um perfil neoliberal moderado que, para Fábio Coelho, "enquanto assegura aos particulares a primazia da produção e circulação dos bens e serviços, baliza a exploração dessa atividade com a afirmação de valores que o interesse egoístico do empresariado comumente desrespeita.. ${ }^{78}$

Nesse sentido, observa-se que o artigo 170 da CRFB elenca bens jurídicos supraindividuais que podem ensejar diversos tipos legais de injusto, diretamente protegidos em cada figura delitiva, conforme regulamentação pela legislação ordinária. ${ }^{79}$ Tal concepção, segundo Regis Prado, fundamenta em sede penal um conceito amplo de delito econômico, mas não totalizador ou amplíssimo. ${ }^{80}$

Enquanto isso, o artigo 173 da Carta Magna, que trata sobre as hipóteses de intervenção estatal direta na economia, determina em seu $\S 4^{\circ}$ que a lei deve reprimir o abuso do poder econômico que vise à dominação

\footnotetext{
${ }^{77}$ Artigo 157, Constituição de 1967. Artigo 160, EC nº 1 de 1969.

${ }^{78}$ COELHO, Fábio Ulhoa. Curso de Direito Comercial. Vol.1. 13a ed., São Paulo: Saraiva, 2009. apud apud PRADO, Luiz Regis. Direito penal econômico - 7 ed. rev. e atual. - São Paulo: Editora Revista dos Tribunais. 2016, p. 44.

${ }^{79}$ Artigo 170, CRFB. “A ordem econômica, fundada na valorização do trabalho humano e na livre iniciativa, tem por fim assegurar a todos existência digna, conforme os ditames da justiça social, observados os seguintes princípios: I - soberania nacional; II - propriedade privada; III - função social da propriedade; IV - livre concorrência; V - defesa do consumidor; VI - defesa do meio ambiente, inclusive mediante tratamento diferenciado conforme o impacto ambiental dos produtos e serviços e de seus processos de elaboração e prestação; VII - redução das desigualdades regionais e sociais; VIII - busca do pleno emprego; IX - tratamento favorecido para as empresas de pequeno porte constituídas sob as leis brasileiras e que tenham sua sede e administração no País.."

${ }^{80}$ PRADO, Luiz Regis. Direito penal econômico - 7 ed. rev. e atual. - São Paulo: Editora Revista dos Tribunais. 2016, p. 84.
} 
dos mercados, à eliminação da concorrência e ao aumento arbitrário de lucros.

Ademais, o artigo 174 da CRFB dispõe sobre a atuação do Estado enquanto agente normativo e regulador da atividade econômica, estabelecendo a necessidade de regulamentação das funções de fiscalização, incentivo e planejamento, cujas diretrizes seriam determinantes para o setor público e indicativas para o setor privado.

No plano infraconstitucional, passaram a ser criadas leis especializadas, quais sejam as leis de sonegação fiscal - Leis ${ }^{\circ}$ 4.728/1965 e 8.176/1991 -, de proteção ao sistema financeiro - Leis $\mathrm{n}^{\circ}$ 7.102/1983, 7.492/1986 e Lei $n^{\text {o } 13.506 / 2017 ~-~ e ~ a ̀ s ~ r e l a c ̧ o ̃ e s ~ d e ~ c o n s u m o ~-~ L e i ~} n^{\text {o }}$ 8.079/1990 e 8.137/1990 -, de crimes contra a ordem econômica e tributária $^{81}$ - Lei no 8.137/1990 -, de licitações - Lei no 8.666/1993 -, de lavagem de dinheiro - Leis n. 9.613/1998 e 12.683/2012 -, de organização criminosa - Lei n ${ }^{\circ} 12.850 / 2013$.

Ainda que não se trate exaustivamente, insta abordar alguns pontos e críticas tecidas quanto a essas leis. A começar pela proteção das relações de consumo, Regis Prado aponta o caráter altamente criminalizador da Lei $\mathrm{n}^{\mathrm{o}}$ 8.078/1990, na medida em que "erige à categoria de delito uma grande quantidade de comportamentos que, a rigor, não deveriam passar de meras infrações administrativas, em total dissonância com os princípios penais da intervenção mínima e da insignificância“.

Na mesma linha, Sérgio Chastinet ensina que as Leis nº 8.078/1990 e $8.137 / 1990$ bem exprimem os anseios repressivos de um direito penal

\footnotetext{
${ }^{81}$ Segundo Regis Prado, "a tutela penal da ordem tributária se encontra justificada pela natureza supraindividual, de cariz institucional, do bem jurídico, em razão de que são os recursos auferidos das receitas tributárias que dão o respaldo econômico necessário para a realização das atividades destinadas a atender às necessidades sociais". PRADO, Luiz Regis. Direito penal econômico - 7 ed. rev. e atual. - São Paulo: Editora Revista dos Tribunais. 2016, pp. 182-183.
} 
econômico que se afasta dos limites garantistas tradicionais, “como se depreende da utilização de normas penais em branco, tipificações imprecisas e da disciplina sugerida ao concurso de pessoas". Salienta, ainda, a tendência funcionalista dessa tutela penal: ${ }^{82}$

"Entendo que o direito penal que rege as relações de consumo é emblemático da adoção, em nosso ordenamento jurídico, de ideias funcionalistas que privilegiam a prevenção geral positiva em detrimento das garantias fundamentais. Tal posição fica reforçada pelo enfoque estritamente civilístico da matéria, que encerra todo o garantido na ideia de proteção contratual e contribui para tornar o sistema penal ainda mais racional e violento".

Já a Lei de Licitações - Lei nº 8.666/1993 tipifica diversas condutas atentatórias à concorrência e ao regular andamento das licitações promovidas pela Administração Pública, notadamente a fraude à licitação, o afastamento de licitante por meios ilícitos, e a admissão em licitação de empresa ou profissional considerado inidôneo.

Trata-se de uma lei com claro intuito moralizador, o que se compatibiliza, em tese, com os princípios constitucionais que regem a Administração Pública. Nota-se, entretanto, a presença de alguns tipos penais genéricos ou abertos, que acabam, segundo Átila Roesler, ensejando a baixa aplicação prática desses preceitos criminais na lida forense. ${ }^{83}$

A Lei $n^{\circ}$ 8.884/1994 também trouxe inovações relevantes. Em primeiro lugar, foi promovida uma alteração na redação do artigo 312 do Código de Processo Penal, que elenca as hipóteses de decretação da prisão preventiva, para incluir nesse rol a garantia da ordem econômica. ${ }^{84} \mathrm{Criou}-\mathrm{se}$,

\footnotetext{
${ }^{82}$ GUIMARÃES, Sérgio Chastinet Duarte. Tutela penal do consumo - Abordagem dos aspectos penais do Código de Defesa do Consumidor e do Artigo $7^{\circ}$ da Lei $n^{\circ}$ 8.137, de 27.12.1990. Rio de Janeiro: Editora Revan, 2004, p. 11.

83 ROESLER, Átila da Rold. Aspectos criminais da Lei de Licitações. Disponível em: <https://jus.com.br/artigos/5635/aspectos-criminais-da-lei-de-licitacoes>. Acesso em nov. 2018.

${ }^{84}$ Artigo 312, CPP. (Redação atual) "A prisão preventiva poderá ser decretada como garantia da ordem pública, da ordem econômica, por conveniência da instrução criminal, ou para assegurar a aplicação da lei penal, quando houver prova da existência do crime e indício suficiente de autoria”.
} 
assim, um verdadeiro "fast-track" punitivo para combater a impunidade dos crimes econômicos, como será tratado adiante.

Também por meio dessa lei, o CADE foi transformado em autarquia federal vinculada ao Ministério da Justiça, passando a deter jurisdição sobre todo o território nacional para exercer as funções de prevenção, por meio da aprovação dos atos tendentes a limitar ou a prejudicar a livre concorrência (como os de concentração empresarial), bem como de fiscalização e repressão administrativa às infrações da ordem econômica. ${ }^{85}$

No mais, Roberto Gullo destaca a criação da Secretaria de Direito Econômico - SDE, "para suprir a necessidade de um órgão que pudesse agir de forma mais aberta, sem os limites em que se deve conter a ação de um órgão judicante como o $C A D E^{*}$, a qual, apesar de não extinta, teve seu efetivo de cargos transferido para o CADE por meio da Lei ${ }^{\circ} 12.529 / 2011 .{ }^{86}$

A Lei das Organizações Criminosas - Lei $n^{\circ}$ 9.034/1995, ora revogada, versava sobre a utilização de meios operacionais para a repressão de crimes resultantes de ações de quadrilhas ou bandos. Cristina Zackescki conta que essa lei foi fruto de uma acentuada influência da legislação estrangeira autoritária, e exigiu que os operadores do direito buscassem o que seria uma organização criminosa e os agentes que a compunham. ${ }^{87}$

Já o combate específico à lavagem de dinheiro se iniciou com a Lei no 9.613/1998, que criminalizou a conduta, elencou os crimes antecedentes à

\footnotetext{
${ }^{85}$ PRADO, Luiz Regis. Direito penal econômico - 7 ed. rev. e atual. - São Paulo: Editora Revista dos Tribunais. 2016, pp. 48-49.

${ }^{86}$ GULLO, Roberto S. F. apud PRADO, Luiz Regis. Direito penal econômico - 7 ed. rev. e atual. São Paulo: Editora Revista dos Tribunais. 2016, pp. 48-49.

${ }^{87}$ ZACKESCKI, Cristina Maria; GOMES, Patrick Mariano. O que é ordem pública no sistema de justiça criminal brasileiro? Revista Brasileira de segurança pública, São Paulo, v. 10, n. 1, 108-126, fev./mar. 2016.
} 
lavagem, ${ }^{88}$ e criou, no âmbito do Ministério da Fazenda, o Conselho de Controle de Atividades Financeiras - COAF, com a finalidade de fiscalizar, disciplinar e impor normas e sanções administrativas a setores da economia sensíveis às ocorrências de lavagem de dinheiro.

Em seguida, foi a vez do Código Penal sofrer alterações referentes aos crimes econômicos, com as inclusões dos delitos contra a previdência social, quais sejam a apropriação indébita previdenciária e a sonegação de contribuição previdenciária, pela Lei no 9.983/2000, ${ }^{89}$ e dos crimes contra as finanças públicas, pela Lei $\mathrm{n}^{\circ} 10.028 / 2000$.

A Lei $n^{o}$ 12.529/2011 teve por objetivo a estruturação do Sistema Brasileiro de Defesa da Concorrência, por meio (i) da previsão de infrações da ordem econômica e a cominação de penas administrativas, (ii) da alteração da tipificação da Lei ${ }^{\circ}$ 8.137/1990 sobre crimes contra a ordem econômica, (iii) da regulamentação da atuação do CADE, competindo-lhe a instauração de inquérito e processo administrativo para imposição de sanções por infrações à ordem econômica, bem como o controle de concentrações, e (iv) da regulamentação da execução judicial das decisões do CADE.

Em seguida, a redação do tipo penal de lavagem de capitais foi alterada com a Lei $n^{\circ} 12.683 / 2012$, que aumentou sua abrangência para englobar a "dissimulação e ocultação da origem de recursos provenientes de

\footnotetext{
${ }^{88} \mathrm{Na}$ redação original do artigo $1^{\circ}$ da Lei $\mathrm{n}^{\circ} 9.613 / 1998$, os crimes antecedentes eram apenas alguns delitos de maior gravidade: tráfico ilícito de entorpecentes, tráfico de armas, terrorismo respectivo financiamento, crimes contra a Administração Pública (e.g., corrupção), crimes contra o sistema financeiro, crime de extorsão mediante sequestro, crimes praticados por organização criminosa e crime de corrupção de funcionário público estrangeiro.

${ }^{89}$ Trata-se de delitos que não se confundem. Em resumo, a apropriação indébita previdenciária ocorre quando o empregador deixa de repassar à previdência social as contribuições recolhidas dos contribuintes. Já a sonegação previdenciária ocorre quando o empregador manipula as informações prestadas à Previdência Social, quanto ao numerário de empregados, lucros auferidos pela empresa, etc., para suprimir ou reduzir a contribuição social previdenciária devida.
} 
qualquer crime ou contravenção penal”. Moraes Pitombo já tecia críticas a essa nova redação, antes mesmo de ser aprovada: ${ }^{90}$

\begin{abstract}
“Agora, esta correta opção de política criminal vai ser posta em xeque com a eventual aprovação do projeto de reforma da Lei de Lavagem de Dinheiro (Projeto de Lei 209, da Câmara dos Deputados [convertido na Lei 12.683/2012]), por meio do qual se almeja estender a tipicidade legal da lavagem de dinheiro a qualquer infração penal apta a originar bens. Dos crimes contra o patrimônio aos crimes tributários, tudo será universo para se reconhecer crime antecedente ao tipo de lavagem de dinheiro. A par do raciocínio torto do quanto mais crimes anteriores maior a eficácia legal, afirmasse que a generalização dos crimes antecedentes seria anseio dos juízes federais de verem aumentada a competência das Varas Especializadas em Lavagem de Dinheiro. Outra vez, a gula repressiva acarretará indigestão normativa. Afinal, ao se transformar qualquer infração criminosa em crime antecedente à lavagem de dinheiro, perde-se a qualidade das condutas proibidas circunscreverem-se somente em torno de valores constitucionais de peso para sociedade brasileira. Ocorrerá banalização do tipo legal que, na atualidade, se volta a atingir apenas os bens daqueles que executaram crimes graves. A referida proposta de alteração do crime de lavagem de dinheiro, ao contrário da expectativa de alguns, tende a retirar a eficácia da lei penal, com importantes consequências para o ordenamento jurídico-penal".
\end{abstract}

Já com a nova Lei das Organizações Criminosas - Lei nº 12.850/2013, revogou-se as disposições das leis anteriores e do Código Penal sobre o assunto, e passou-se a tipificar a associação de quatro ou mais pessoas, estruturalmente ordenada e caracterizada pela organização de tarefas, para a prática de infrações penais cujas penas máximas sejam superiores a 4 anos, ou que sejam de caráter transnacional.

Finalmente, a Lei $n^{\circ}$ 13.506/2017 dispôs sobre a regulamentação do processo administrativo no âmbito de atuação do Banco Central do Brasil e da CVM, e também estabeleceu as infrações penalidades, medidas cautelares, e meios alternativos de solução de controvérsias aplicáveis às instituições financeiras, às demais instituições supervisionadas pelo Bacen e aos integrantes do Sistema de Pagamentos Brasileiro.

\footnotetext{
${ }^{90}$ PITOMBO, Antônio Sérgio A. de Moraes. A lei de lavagem de dinheiro. São Paulo: Gazeta Mercantil - $\quad$ p. $2007 . \quad$ A-11, Disponível em: <http://www.apitombo.com.br/images/userfiles/file/2_5_16.pdf>. Acesso em nov. 2018.
} 
Rômulo Moreira aponta diversas inconstitucionalidades na referida lei, como por exemplo a aplicabilidade de certas medidas restritivas de direitos que, travestidas no processo administrativo sancionador, dispensariam, em tese, a aplicação dos princípios gerais do direito penal.

Tratam-se medidas coercitivas e acautelatórias a serem adotadas antes da instauração, ou durante a tramitação do processo administrativo, bastando a verificação de verossimilhança das alegações e do perigo de mora, aplicáveis a pessoas físicas ou jurídicas que exerçam atividades sem autorização, bem como aos administradores e responsáveis técnicos. ${ }^{91}$

Verifica-se, portanto, violação ao princípio constitucional da reserva de jurisdição, eis que as medidas restritivas de direitos não poderiam ser aplicadas diretamente por uma autoridade administrativa, exigindo-se a decretação por meio de autoridade judicial, a requerimento de autoridade policial ou do Ministério Público.

91 Ele traz, como exemplos: a obrigação de prestar informações; afastamento da função; impedimento de atuação em determinados órgãos do sistema financeiro; restrições à realização de determinadas atividades ou modalidades de operações. MOREIRA, Rômulo de Andrade. Lei que trata processo administrativo do Banco Central do Brasil é restritiva de direito. Disponível em: $<$ http://www.justificando.com/2017/11/17/lei-que-trata-processo-administrativo-do-banco-centraldo-brasil-e-restritiva-de-direito/>. Acesso em nov. 2018. 


\section{Da seletividade reversa no combate à impunidade}

Se sob a perspectiva histórico-garantista os direitos penal e processual penal evoluíram para resguardar as prerrogativas individuais, surgem questionamentos desafiadores: como conciliar um direito que pretende regulamentar eficazmente a intervenção do Estado na economia (direito econômico), mas ao que mesmo tempo busca tutelar as garantias individuais da pessoa acusada (direito penal)? Trata-se de um direito econômico penal ou de um direito penal econômico?

Para elucidar a questão, aponta-se que, de um lado, há a tutela da ordem econômica prevista no artigo 170 da Constituição Federal, de modo que o rol de princípios norteadores dos incisos já podem dar ensejo a leis penais econômicas, enquanto, do outro, estão as garantias fundamentais previstas no artigo $5^{\circ}$ da CRFB, dentre as quais o princípio da presunção de inocência.

Decerto, tendo em vista o princípio da unidade da Constituição, normas originárias da Constituição não são controláveis entre si e, assim, não conflito aparente de normas, porque não existe hierarquia entre normas constitucionais. O que pode ocorrer é a Constituição relativizar ou excepcionar a si mesma. ${ }^{92}$

\footnotetext{
${ }^{92}$ O STF sedimentou tal entendimento em dois momentos: (i) julgamento da ADI ajuizada contra o artigo 142, p. 2o, da CRFB, que estabelece o alistamento militar obrigatório para homens, por afronta ao artigo $5^{\circ}$, I, da CRFB, que prevê a garantia fundamental à igualdade de direitos e obrigações entre os gêneros; (ii) julgamento da ADI 815 , que pugnava pela inconstitucionalidade da segunda parte do artigo 45 da CRFB em face da primeira parte do mesmo artigo, que concordava com a democracia representativa prevista no artigo $1^{\circ}$ da CRFB, com base na tese de Otto Bachof, exposta em seu livro "Normas constitucionais inconstitucionais?", de que as normas constitucionais originárias devem respeito aos princípios fundamentais.
} 
Para tanto, algumas características do direito penal econômico justificariam, em tese, um tratamento diferenciado ao acusado. Trata-se de um direito penal secundário ou especial, coincidente com os direitos humanos de segunda geração, que possuem cunho social e trabalhista, e buscam tutelar bens jurídicos supraindividuais, como a ordem econômica, administração pública, incolumidade pública, fé pública.

Denota-se, desde logo, as dificuldades de se trabalhar com os conceitos desses bens jurídicos, e de se mensurar tanto as consequências de um delito no âmbito da ordem econômica (e quem foram as vítimas), quanto a própria culpabilidade do sujeito que cometa um crime econômico.

Em crimes comuns como, por exemplo, uma lesão à integridade física de outrem, pode-se bem delinear a conduta, o resultado, o agente, a vítima, o local, a data e a hora. Já nos crimes econômicos, a tendência é de que sejam realizados em ambientes empresariais, dentro de espaços privados e, portanto, de acesso restrito, acobertados por vínculos hierárquicos, e não possuam, em geral, consequências visíveis de pronto.

Em nome da necessária eficiência da regulação do Estado na economia, defende-se a administrativização do direito penal, na medida em que a posição socioeconômica privilegiada do acusado passou a levantar dúvidas sobre a real necessidade de lhe oportunizar as mesmas garantias penais e processuais penais de que dispõem os demais acusados.

Nesse diapasão, a administrativização seria a invocação do poder de polícia que o Estado possui de limitar as atividades individuais para gerir setores sociais (como a economia, o meio ambiente, etc.) e, assim, por meios de coação mais direta, concretizar as pretensões persecutória e punitiva. 
Assim, seria cabível, por exemplo, a adoção de medidas cautelares de investigação sem provimento jurisdicional prévio, e de regras de inversão de ônus da prova, relativizando assim as garantias processuais penais do acusado. ${ }^{93}$ De acordo com Douglas Silva: ${ }^{94}$

"[...] o direito penal passa a ser "chamado" como regulador dos setores sociais criadores de riscos, impondo, sob pena de sanção, que estes assumam condutas dirigidas a reduzir ou impedir o incremento do perigo de determinadas atividades".

Contudo, sendo o direito penal a ultima ratio, a solução lógica para combater os crimes econômicos não poderia ser, de pronto, esse ramo do direito. ${ }^{95}$ Cumpre relembrar a existência de vias administrativas para promover a prevenção, fiscalização e repressão dos crimes econômicos, por meio do CADE e das agências reguladoras. Como bem destaca Regis Prado: ${ }^{96}$

“Embora admitida e, muitas vezes, necessária, a intervenção penal nesse campo se apresenta com frequência excessiva, mais como prima ratio do que como ultima ratio, em constante fricção com os princípios da intervenção mínima e da fragmentariedade, o que de resto muitas vezes só põe em evidência o descompasso com a verdadeira missão do Direito Penal do Estado democrático e social de Direito".

Nesse sentido, no Colóquio Preparatório do Grupo Brasileiro da AIDP de 1982, ocorrido no Rio de Janeiro, diversos juristas brasileiros se uniram para elaborar recomendações a serem levadas para o XIII Congresso Internacional de Direito Penal, ocorrido no Cairo, Egito, em 1984, que tinha como tema os princípios do direito penal econômico.

\footnotetext{
${ }^{93}$ SILVA SÁNCHEZ, Jésus-Maria. A expansão do direito penal: aspectos da política criminal nas sociedades pós-industriais. Tradução de Luiz Otavio de Oliveira Rocha. 3. ed. rev. e. atual. São Paulo: Editora Revista dos Tribunais, 2013, p. 148.

${ }^{94}$ SILVA, Douglas R. Normas penais em branco são inconstitucionais? Canal Ciências Criminais. Disponível em: 〈https://canalcienciascriminais.com.br/normas-penais-em-branco/>. Acesso em nov. 2018

${ }^{95}$ Também se ressalta o papel do direito civil, que proporciona meios também adequados à defesa da ordem econômica voltados às noções jurídicas de propriedade, de responsabilidade civil, e de contratos.

${ }^{96}$ PRADO, Luiz Regis. Direito penal econômico - 7 ed. rev. e atual. - São Paulo: Editora Revista dos Tribunais. 2016, prefácio.
} 
Nas resoluções finais do XIII Congresso, restaram consignadas resoluções no sentido de reconduzir o direito penal econômico aos princípios gerais do direito penal, em especial da intervenção mínima. Buscou-se, assim, reafirmar a presunção de inocência do acusado frente ao poder público e, assim, limitar a punitividade aos padrões democráticos. ${ }^{97}$

Para mais, sustenta Raúl Zaffaroni que, em verdade, a repressão penal da atividade econômica não apenas é ineficiente para a prevenção, como fomenta as atividades ilícitas, às custas das garantias individuais preceituadas no direito penal e processual penal. In verbis: ${ }^{98}$

\begin{abstract}
“A intervenção punitiva no mercado é um fenômeno que se introduz em todos os mutantes e instáveis buracos de indisciplina que este vai abrindo, sem uma categoria reitora e sem que possa deixar de interferir também nas atividades legais. Termina sendo um conjunto de medidas de protecionismo irracional ou arbitrariamente selecionado, que com demasiada frequência aumentar as próprias atividades ilícitas, a corrupção [...], destrói a competitividade do empresariado mais débil e o elimina do mercado, podendo tomar partido como elemento decisivo nas disputas entre os mais fortes [...] Pode-se afirmar que o transporte à lei de uma categoria criminológica frustrada, que trataram de inventar os criminólogos norteamericanos, por pressão dos políticos, das corporações policiais e dos meios de massa, não tem outro efeito que lesionar de forma plural a legalidade no direito penal e o acusatório no processo penal."
\end{abstract}

A seguir, serão abordadas algumas questões controvertidas que bem exprimem o embate entre as garantias constitucionais do acusado e a pretensão de se aumentar a efetividade da repressão aos crimes econômicos por meio do direito penal.

\footnotetext{
${ }^{97}$ CUESTA, J. L.; CORDERO, Blanco Cordero. Resolutions of the Congresses of the International Association of Penal Law. International Review of Penal Law, vol. 86, pp. 338-340. Disponível em: 〈http://www.penal.org/sites/default/files/RIDP86\%201-2\%202015\%20EN.pdf〉. Acesso em nov. 2018. Na ocasião do Colóquio, João Marcello de Araújo Júnior, Eduardo Novoa Monreal, Eugenio Raúl Zaffaroni, Heleno Cláudio Fragoso, João Mestieri, Juarez Cirino dos Santos, Miguel Reale Júnior, Nilo Batista, René Ariel Dotti e Virgílio Luiz Donnici, discutiram longamente suas idéias sobre o assunto. $\mathrm{O}$ debate intensificou-se e aprofundou-se durante o citado Congresso Internacional, momento no qual os especialistas brasileiros tiveram oportunidade de trocar, com penalistas do mundo inteiro, suas opiniões e experiências.

${ }^{98}$ ZAFFARONI, Eugenio Raúl. Crime Organizado: uma categorização frustrada. Discursos Sediciosos - Crime, direito e sociedade. Rio de Janeiro: Instituto Carioca de Criminologia, 1996, vol. 1.
} 


\title{
III.1. Aspectos penais
}

\section{III.1.1. Crimes de perigo abstrato}

Entende-se por crimes de perigo aqueles perpetrados por meio da criação de situações que colocam em risco determinados bens jurídicos, e podem ser classificados como crimes de perigo concreto, no qual a tipificação faz menção expressa ao resultado do perigo, ou como crimes de perigo abstrato, em que há presunção de risco ao bem jurídico.

Quanto aos crimes de perigo abstrato, a jurisprudência vem sedimentando entendimento no sentido de que haveria uma presunção absoluta da periculosidade de lesão a bem jurídico, não podendo a defesa produzir prova em contrário.

Tal instrumento normativo vem sendo cada vez mais utilizado pelo poder legislativo para restringir os riscos em atividades de grande interesse coletivo ou de alto potencial lesivo, bem como em situações em que a relação de causalidade é de difícil comprovação. Natural, então, que se tornassem uma alternativa interessante para as tipificações de crimes econômicos.

Como bem explica Pierpaolo Bottini, a norma penal passa a significar verdadeira antecipação de tutela, para assegurar a punibilidade dos criminosos frente a um contexto dinâmico de desenvolvimento científico e econômico: ${ }^{99}$

\begin{abstract}
"Não interessa ao gestor de riscos atuar após a ocorrência da lesão, mas anteciparse a ela, diante da magnitude dos danos possíveis. Nestas circunstâncias, a norma penal surge como elemento de antecipação da tutela, sob uma perspectiva que acentua o papel preventivo do direito. Para isso, o tipo penal deve estar dirigido à conduta e não ao resultado. A atividade, em si, passa a ser o núcleo do injusto. A insegurança que acompanha estas condutas, e a extensão da ameaça, levam o
\end{abstract}

${ }^{99}$ BOTTINI, Pierpaolo Cruz. Princípio da precaução, direito penal e sociedade de risco. Revista Brasileira de Ciências Criminais, São Paulo, v. 61, p. 44-121, julho-agosto 2006, pp. 66-69. 
legislador a optar pela norma de prevenção, através de descrições típicas que não reconheçam o resultado objetivo como elemento integrante do injusto, ou seja, através dos tipos penais de perigo abstrato [...] o porquê da massificação dos delitos de perigo abstrato no direito penal do risco. Os novos âmbitos de periculosidade, com suas características inéditas, direcionam a atividade legislativa ao emprego desta técnica de tipificação, daí sua presença representativa nos diplomas legais contemporâneos. O perigo abstrato representa o sintoma mais nítido da expansão do direito penal, na ânsia por fazer frente aos temores que acompanham o desenvolvimento científico e econômico da atualidade."

Notadamente, trata-se de um mecanismo de implementação de políticas públicas, em especial quando atinentes à segurança - e.g., criminalização da conduta de direção de veículo automotor sob a influência de álcool ou de substâncias psicoativas, com base no Código de Trânsito Brasileiro, ${ }^{100}$ e criminalização do porte de arma, ${ }^{101}$ ainda que desmuniciada, com fulcro no Estatuto do Desarmamento.

Contudo, em muito questiona-se a constitucionalidade dos crimes de perigo abstrato, à luz do princípio da ofensividade ou da lesividade, ${ }^{102}$ segundo o qual se faz necessária a demonstração da tipicidade material da conduta, isto é, de lesão significativa ou, ao menos, de perigo significativo a bem jurídico, para ensejar a tutela do direito penal. No entender de Maurício Borba, tutelam-se: ${ }^{103}$

\footnotetext{
100 "STJ reafirma que crime de embriaguez ao volante não exige prova de perigo concreto. A Sexta Turma do Superior Tribunal de Justiça (STJ) reafirmou o entendimento de que dirigir com concentração de álcool acima do limite legal configura crime, independentemente de a conduta do motorista oferecer risco efetivo para os demais usuários da via pública.” Disponível em: $<$ https://www.conjur.com.br/2016-abr-10/stj-reafirma-embriaguez-volante-nao-exige-perigoconcreto $>$. Acesso em nov. 2018.

${ }^{101}$ Precedente paradigma: STF, $2^{\text {a }}$ Turma, HC n ${ }^{\circ}$ 102.087/MG, Rel. Min. Gilmar Mendes, DJE 14.08.2012.

${ }^{102}$ Nilo Batista enumera quatro funções do principio da lesividade: (i) "proibir a incriminação de uma atitude interna", de modo que não seria possível responsabilizar criminalmente alguém sem que tenha realizado uma conduta com o intuito de atingir bem alheio, ainda que tenha existido a cogitação; (ii) "proibir a incriminação de uma conduta que não exceda o âmbito do próprio autor", assim, os atos de preparação, bem como a auto lesão; (iii) "proibir a incriminação de simples estados ou condições existenciais", tratando-se, pois, de suprimir o direito penal do autor para dar lugar ao direito penal do fato; (iv) "proibir a incriminação de condutas desviadas que não afetem qualquer bem jurídico". BATISTA, Nilo. Introdução Crítica ao Direito Penal Brasileiro. Rio de Janeiro. Editora Revan. 12 edição. 2011. pp. 92 e seguintes.

${ }^{103}$ BORBA, Maurício. A Inconstitucionalidade dos Crimes de Perigo Abstrato. Revista Jurídica da UNIFACS. Apus LUZ, Renata C. D. A constitucionalidade dos crimes de perigo abstrato: a tipicidade do porte de arma de fogo desmuniciada com base na jurisprudência do STJ e do STF. Disponível em: <https://jus.com.br/artigos/20877/a-constitucionalidade-dos-crimes-de-perigo-
} 
"...] por meio dos crimes de perigo presumido, bens jurídicos que poderia ser protegidos com muito mais eficácia através de outros ramos do Direito, como o Direito Administrativo, o Direito Tributário e o Direito Civil. O Direito penal mostra-se inadequado e lento para oferecer uma proteção adequada a estes bens e, por outro lado, não pode ser utilizado como mera função simbólica, satisfazendo os anseios da sociedade pela tutela de bens jurídicos recém criados ou recém valorados. Incompatível, portanto, com o princípio da intervenção mínima.”

Diego Romero ainda explica que a excessiva tipificação desses crimes, em que pese eivados de inconstitucionalidade frente aos princípios constitucionais do direito penal, representa a exacerbada preocupação prevencionista na sociedade contemporânea. Senão vejamos: ${ }^{104}$

"...] a excessiva tipificação dos crimes de perigo abstrato, em flagrante contradição aos princípios que são vigas-mestras do ordenamento constitucional e penal brasileiro, represente-a essa exacerbada preocupação prevencionista do direito criminal da sociedade contemporânea, que a par de uma transformação social, processada a velocidade da comunicação global instantânea, de um processo tecnológico inimaginável e imprevisível, quer antecipar a punição de condutas, com o fim de prevenir perturbações e garantir segurança, usando, para isso, o recurso do simbolismo da lei penal e da intimidação dos cidadãos com o estigma da punição criminal."

A vedação às tipificações de perigo abstrato pode ser inferida diretamente do texto constitucional, na medida em que se garante a dignidade da pessoa humana e o respeito à sua liberdade, que se efetivam em um contexto de intervenção mínima do Estado, especialmente em matéria penal, que somente deve se realizar quando necessária à real defesa dos bens jurídicos, quando há violação ou perigo concreto, que depende do resultado.

Denota-se que ocorre uma dupla violação ao princípio constitucional da presunção de inocência: de um lado, aceita-se a presunção mais abstrata possível, qual seja a presunção de ameaça de lesão a bem jurídico relevante;

abstrato-a-tipicidade-do-porte-de-arma-de-fogo-desmuniciada-com-base-na-jurisprudencia-do-stje-do-stf/6>. Acesso em nov. 2018.

${ }^{104}$ ROMERO, Diego. Reflexões sobre os Crimes de Perigo Abstrato. Revista IOB Direito Penal e Processual Penal, São Paulo, v. 39, p. 43-62, ago.-set. 2006, p. 59. 
de outro, admite-se essa presunção de forma absoluta, não cabendo a produção de prova em contrário.

A presunção de inocência, enquanto reitora do processo penal, repudia o levantamento de quaisquer presunções em desfavor do réu. Assim, os crimes de perigo abstrato não só afetam o acusado no plano da culpabilidade, como acabam por esvaziar, em grande parte, o exercício das garantias de ampla defesa e contraditório, de forma que o processo penal deixaria de ser uma oportunidade de defesa, para se tornar, então, uma mera formalidade para a confirmação da culpa.

No âmbito dos crimes econômicos, tem-se alguns exemplos, como o artigo 17 da Lei $n^{\circ} 7.492 / 1986$, que proíbe o administrador de instituição financeira de emprestar dinheiro a si próprio ou a seus familiares. Trata-se de um crime de perigo abstrato, porque em tese se põe em risco a instituição financeira, mas parece teratológico impedir que a defesa comprove que o empréstimo foi vantajoso à instituição e que não traria risco à segurança e à estabilidade da instituição.

$\mathrm{Na}$ mesma lei, há ainda a tipificação da gestões fraudulenta e temerária pelo artigo $4^{\circ}$, caput e parágrafo único, enquanto crimes de mera atividade contra o sistema financeiro, que portanto independem de qualquer resultado danoso. Já no artigo 10 da Lei Complementar n 105/2001, há o crime de quebra de sigilo das operações de instituições financeiras fora das hipóteses autorizadoras, que prescinde de qualquer resultado danoso.

A atual posição do Supremo a respeito dos crimes de perigo abstrato, proferida na decisão que reputou constitucional a criminalização do porte de arma desmuniciada, é de que a punibilidade deve ser sopesada com o princípio da proporcionalidade: 
“A criação de crimes de perigo abstrato não representa, por si só, comportamento inconstitucional por parte do legislador penal. A tipificação de condutas que geram perigo em abstrato, muitas vezes, acaba sendo a melhor alternativa ou a medida mais eficaz para a proteção de bens jurídico-penais supraindividuais ou de caráter coletivo, como, por exemplo, o meio ambiente, a saúde etc.Portanto, pode o legislador, dentro de suas amplas margens de avaliação e de decisão, definir quais as medidas mais adequadas e necessárias para a efetiva proteção de determinado bem jurídico, o que lhe permite escolher espécies de tipificação próprias de um direito penal preventivo. Apenas a atividade legislativa que, nessa hipótese, transborde os limites da proporcionalidade, poderá ser tachada de inconstitucional." (STF, $2^{\mathrm{a}}$ Turma, $\mathrm{HC}^{\circ}$ 102.087/MG, Rel. Min. Gilmar Mendes, DJE 14.08.2012)

Em que pese remanescer aberta a possibilidade de discussão da proporcionalidade em cada caso, Eduardo Cabette aponta que o STF já vem adotando um método para se furtar da inflexível presunção absoluta imposta aos crimes de perigo abstrato, e impedir distorções: desvirtuar tipos penais e interpretá-los forçosamente, mesmo contra legem, como se fossem de perigo concreto. ${ }^{105}$

De todo modo, tem-se que, para fins de tipificação, o princípio da proporcionalidade deveria ser utilizado para resguardar os direitos fundamentais frente a potenciais excessos do legislador, e se subdivide nos princípios da adequação, da necessidade, e da proporcionalidade em sentido estrito.

Nesse diapasão, cabe ressaltar que, do voto do Ministro Gilmar Mendes, infere-se ao menos a adequação dos crimes de perigo abstrato para

\footnotetext{
${ }^{105}$ Um exemplo estaria na edição do Enunciado de Súmula n ${ }^{\circ} 720$ do STF, que dispõe que o art. 309 do Código de Trânsito Brasileiro, que reclama decorra do fato perigo de dano, derrogou o art. 32 da Lei das Contravenções Penais no tocante à direção sem habilitação em vias terrestres. Assim, o crime de dirigir sem habilitação seria de perigo concreto, e não abstrato.

CABETTE, Eduardo. A falácia do denominado "crime de perigo abstrato de perigosidade real". Disponível em: <https://eduardocabette.jusbrasil.com.br/artigos/151085894/a-falacia-dodenominado-crime-de-perigo-abstrato-de-perigosidade-real>. Acesso em nov. 2018.
} 
a tutela de bens jurídicos de natureza supraindividual, o que se compatibiliza com a tutela da ordem econômica em sentido amplo conferida pelo direito penal econômico.

\section{III.1.2. Normas penais em branco}

As normas penais, em regra, traziam o preceito primário da sanção penal de forma satisfativa. Contudo, há uma tendência crescente de criação de tipos penais que demandam complementação às sanções estabelecidas, a qual pode ocorrer por meio de espécie normativa homóloga, quando proveniente da mesma fonte legislativa (lei em sentido formal), ou de espécie normativa heteróloga (decretos, resoluções, portarias).

De acordo com Rogério Greco, tratam-se das normais penais cujo complemento é extraído de outro diploma "para que possam, efetivamente, ser entendidos os limites da proibição ou imposição feitos pela lei penal, uma vez que, sem complemento, torna-se impossível a sua aplicação."106

Divide-se, ainda, a norma penal em branco de complementação homóloga a depender da coincidência ou não entre os ramos do direito em que residem a norma sancionadora e a norma complementar. Seriam homovitelinas, quando tanto a primeira quanto a segunda fossem leis penais, e heterovitelinas, quando a norma complementar adviesse de outro ramo do direito.

Exemplo de complementação homóloga heterovitelina se encontra no artigo $7^{\circ}$, IX da Lei $\mathrm{n}^{\circ} 8.137 / 1990$, que tipifica o comércio de mercadorias em condições impróprias para consumo, cuja aplicação deve se valer da definição de "mercadorias em condições impróprias para consumo“ prevista

\footnotetext{
106 GRECO, Rogério. Curso de direito penal: Parte Geral. 17 ed. Rio de Janeiro: Impetus, 2015, p. 69-73.
} 
no artigo 18, $\S 6^{\circ}$, do Código de Defesa do Consumidor. Quanto a essa modalidade de norma penal em branco, não há maiores controvérsias.

Já na segunda modalidade, cuida-se de situações em que o legislador, ciente de sua falta de conhecimento técnico-científico para regulamentação de determinados setores econômicos e sociais, delega essa função aos órgãos reguladores especialistas (ANATEL, ANVISA, ANP, IBAMA), no âmbito do Poder Executivo. ${ }^{107}$

Para mais, a complementação heteróloga teria grande utilidade, porque conferiria dinamicidade à sanção penal, especialmente ao se tratar de matérias que estão em constante evolução, ou que por natureza dependam de revisão periódica. Do contrário, seria necessário mover a máquina pública do processo legislativo com uma regularidade indesejada.

Tem-se, por exemplo, a Lei de Drogas - Lei n ${ }^{\circ}$ 11.343/2006, cujos crimes dependem das disposições regulamentares da ANVISA que indicam, por meio de portaria do Ministério da Saúde, quais as substâncias entorpecentes proibidas no país. ${ }^{108}$ Há ainda o artigo 45 da Lei de Crimes Ambientais - Lei $n^{\circ} 9.605 / 1998$, que proíbe cortar madeira em desacordo com as determinações legais de quantidade.

Próprio à matéria econômica, há o artigo $6^{\circ}$, I e III, da Lei $n^{\circ}$ $8.137 / 1990$, que trata de condutas que infrinjam o tabelamento de preços fixado pelo poder público, exigindo como complemento administrativo necessário uma tabela oficial de preços. ${ }^{109}$

\footnotetext{
${ }^{107}$ BACH, Marion; GUARAGNI, Fábio André. Norma penal em branco e outras técnicas de reenvio em direito penal. São Paulo: Almedina, 2014.

108 Trata-se da Portaria SVS/MS no 344/1998, que contém, em seu Anexo I, Listas de Substâncias Entorpecentes, Psicotrópicas, Precursoras e Outras sob Controle Especial, cuja atualização mais recente se deu pela Resolução RDC no 227/2018.

${ }^{109}$ Artigo 6 ${ }^{\circ}$, Lei n ${ }^{\circ} 8.137 / 1990$. “Art. $6^{\circ}$ Constitui crime da mesma natureza: I - vender ou oferecer à venda mercadoria, ou contratar ou oferecer serviço, por preço superior ao oficialmente tabelado,
} 
Os defensores desse modelo alegam que bastaria a existência de um preceito sancionador, ainda que não determinasse por completo a ação proibida, porque a sanção da norma seria apenas um pressuposto para sua aplicação.

De outro lado, argumenta-se que essa normatização viola o princípio constitucional da anterioridade da lei penal, uma vez que, segundo Hans Welzel, esse princípio não se reduz à existência de uma lei anterior, mas também demanda que a lei defina com exatidão os crimes nela cominados, de modo que "o verdadeiro perigo para o princípio nulla poena sine lege não provém da analogia, mas das leis penais imprecisas.. ${ }^{110}$

Ademais, Greco aponta ofensa ao princípio da legalidade formal, tendo em vista que afastar as regras do processo legislativo para criação modificação das normas significa negar ao povo e aos Estados sua representatividade no Congresso Nacional, bem como impedir o controle do Poder Executivo, essencial no sistema de freios e contrapesos. ${ }^{111}$

Nesse sentido, Zaffaroni et al. denunciam que, assim, o legislador penal está, concomitantemente, ferindo o princípio da lei penal em sentido estrito, ao renunciar à sua função programadora de criminalização primária e

\footnotetext{
ao regime legal de controle; II - aplicar fórmula de reajustamento de preços ou indexação de contrato proibida, ou diversa daquela que for legalmente estabelecida, ou fixada por autoridade competente; III - exigir, cobrar ou receber qualquer vantagem ou importância adicional de preço tabelado, congelado, administrado, fixado ou controlado pelo Poder Público, inclusive por meio da adoção ou de aumento de taxa ou outro percentual, incidente sobre qualquer contratação. Pena - detenção, de 1 (um) a 4 (quatro) anos, ou multa."

110 WELZEL, Hans. Das DeutscheStrafrecht: De Gruyer Lehrbruch, 1969. apud JESCHECK, HansHeinrich. Tratado de derecho penal: parte general 4. ed. Granada: Comares, 1993, p. 122, apud FRANCO, Alberto Silva. Código penal e sua interpretação jurisprudencial: parte geral. São Paulo: Ed. Revista dos Tribunais, 1997.

${ }^{111}$ Ressalte-se que, nos termos do artigo 22, I, da CRFN, compete à União legislar em matéria penal. GRECO, Rogério. Curso de direito penal: Parte Geral. 17 ed. Rio de Janeiro: Impetus, 2015, p. 6973.
} 
delegá-la a funcionários e órgãos do Poder Executivo, e abdicando da cláusula da ultima ratio do direito penal, que rege o Estado de Direito. ${ }^{112}$

Os autores também rechaçam o argumento da suposta instabilidade das matérias disciplinadas pela legislação penal, sustentando que "não há matéria que requeira mudanças tão rápidas e que seja, seriamente, carente de previsão punitiva; por outro lado, essa é precisamente a irrenunciável função constitucional do legislador.:

Em matéria penal, faz-se imperioso o princípio da taxatividade, que veda interpretações ampliativas na aplicação do direito penal. Nessa linha, critica-se ainda o tipo penal aberto, em que o elemento normativo depende de uma valoração interpretativa, e que também deve ser refutado à luz da principiologia penal constitucional.

Essa abertura para as mais diferentes visões não poderia subsistir, eis que gera dúvidas sobre sua abrangência, como é o caso do crime previsto no artigo 19 da Lei $\mathrm{n}^{\mathbf{0}}$ 7.492/1986, de obter financiamento em instituição financeira mediante fraude, sem se definir o que seria considerado financiamento para fins desta lei. ${ }^{113}$

\section{III.2. Aspectos processuais penais}

\section{III.2.1. Medidas cautelares}

As medidas cautelares são aquelas adotadas em detrimento das garantias individuais do acusado, durante a fase investigatória ou após instaurada ação penal, sob o pretexto de, em suma, resguardar o regular

\footnotetext{
112 ZAFFARONI, Eugenio Raúl; BATISTA, Nilo; ALAGIA, Alejandro; SLOKAR, Alejandro, Direito Penal Brasileiro: primeiro volume. Rio de Janeiro: Revan, 2003, $4^{\mathrm{a}}$ edição, 2011. $2^{\mathrm{a}}$ reimpressão, 2015, pp. 205-207.

${ }^{113}$ Em sentido estrito, o financiamento realizado pelas instituições financeiras se dá pelo empréstimo de dinheiro, que será posteriormente cobrado com juros. Já em sentido amplo, o financiamento também abarcaria as operações mutuárias, em que o empréstimo está vinculado à venda de um bem ou serviço.
} 
andamento da ação penal e a devida prestação jurisdicional ao cabo do processo.

Sob essa perspectiva, tem-se dois tipos de medidas cautelares: (i) contra a liberdade individual, que se consubstancia nas prisões temporária e preventiva; 114 (ii) contra o patrimônio, também chamadas medidas assecuratórias.

Em que pese consideradas constitucionais, as medidas cautelares sofrem diversas limitações, a depender da natureza do bem jurídico mitigado em favor do processo penal, como o princípio constitucional da legalidade formal, que demanda a estrita observância aos requisitos legalmente impostos para a imposição de restrições ao acusado. ${ }^{115}$

Há de se ressaltar os ensinamentos de Guilherme Nucci, no sentido de que a presunção de inocência também se refere ao ônus conferido à acusação de comprovar a excepcionalidade e a necessidade quando da adoção de medidas cautelares que restrinjam direitos do acusado, tanto com viés investigativo quanto assecuratório. Veja-se: ${ }^{116}$

\begin{abstract}
"Por outro lado, confirma a excepcionalidade e a necessariedade das medidas cautelares de prisão, já que indivíduos inocentes somente podem ser levados ao cárcere quando realmente for útil à instrução e à ordem pública. A partir disso, deve-se evitar a vulgarização das prisões provisórias, pois muitas delas terminam por representar uma nítida - e indevida - antecipação de pena, lesando a presunção
\end{abstract}

\footnotetext{
${ }^{114}$ Há ainda a prisão em flagrante, disciplinada pelos artigos 301 e ss. do CPP, que contudo não se trata de medida cautelar, mas pré-cautelar, porque tem como fim apenas fazer cessar ou interromper os efeitos da conduta delitiva. Segundo Aury Lopes Jr., se a prisão em flagrante fosse considerada cautelar, uma vez presentes seus requisitos, ela seria suficiente para manter o indivíduo preso por tempo indeterminado, o que não ocorre. Em 2015, o Conselho Nacional de Justiça editou a Resolução CNJ n 213 para promover a implementação das audiências de custódia nos tribunais, por meio da qual os presos em flagrante delito devem ser apresentados a uma autoridade judicial, para que decida sobre o relaxamento ou conforme previsto em diversos documentos internacionais assinados pelo Brasil, como o Pacto Internacional de Direitos Civis e Políticos e o Pacto de San José da Costa Rica. Segundo noticia o próprio CNJ, ainda em 2018 o novo sistema ainda não tinha sido implementado integralmente em muitos tribunais.

115 Art. 5 , II, CRFB. “II - ninguém será obrigado a fazer ou deixar de fazer alguma coisa senão em virtude de lei;"

${ }^{116}$ NUCCI, Guilherme de Souza. Manual de processo penal e execução penal: 14 ed. rev., atual. e ampl. - Rio de Janeiro: Forense, 2017, pp. 33-34.
} 
de inocência. No mesmo prisma, evidencia que outras medidas constritivas aos direitos individuais devem ser excepcionais e indispensáveis, como ocorre com a quebra dos sigilos fiscal, bancário e telefônico (direito constitucional de proteção à intimidade), bem como com a violação de domicílio em virtude de mandado de busca (direito constitucional à inviolabilidade de domicílio."

O artigo 282 do Código de Processo Penal determina que as medidas cautelares limitadoras de liberdade observem dois parâmetros: (i) a necessidade para aplicação da lei penal, para a investigação ou a instrução criminal, e para evitar a prática de infrações penais; (ii) a adequação da medida à gravidade do crime, circunstâncias de fato e condições pessoais do indiciado ou acusado. ${ }^{117}$

Rodrigo Capez alerta que, apesar de no processo civil admitir-se o poder geral de cautela para a adoção de medidas cautelares atípicas ou inominadas, em nome das tutelas provisórias, o mesmo não se aplica ao processo penal, porquanto limitador do poder punitivo estatal, exigindo-se a legalidade - nulla coactio sine lege - e a taxatividade para que se proceda à restrição da liberdade. Nesse sentido: ${ }^{118}$

“...] as medidas cautelares limitadoras da liberdade reduzem-se a um número fechado de hipóteses, sem espaço para aplicações analógicas ou outras intervenções (mais ou menos criativas) do juiz, ainda que a pretexto de favorecer o imputado. Trata-se de uma enumeração exaustiva (numerus clausus), e não de uma lista aberta, meramente exemplificava (numerus apertus)".

Além da representação policial ou requerimento ministerial prévio, a prisão temporária deve preencher alguma das hipóteses do $\operatorname{artigo~} 1^{\circ}$ da Lei $n^{\circ}$ 7.960/1989, quais sejam (i) a imprescindibilidade às investigações do

\footnotetext{
${ }^{117}$ Artigo 282, caput, I e II, CPP. “Art. 282. As medidas cautelares previstas neste Título deverão ser aplicadas observando-se a: I - necessidade para aplicação da lei penal, para a investigação ou a instrução criminal e, nos casos expressamente previstos, para evitar a prática de infrações penais; II - adequação da medida à gravidade do crime, circunstâncias do fato e condições pessoais do indiciado ou acusado".

${ }^{118}$ CAPEZ, Rodrigo. No processo penal não existe o poder geral de cautela. Disponível em: $<$ https://www.conjur.com.br/2017-mar-06/rodrigo-capez-processo-penal-nao-existe-poder-geralcautela>. Acesso em nov. 2018. No mesmo sentido: BADARÓ, Gustavo Henrique. Processo Penal - 5 ed. rev., atual e ampl. - São Paulo: Editora Revista dos Tribunais, 2017, p. 1086-1088.
} 
inquérito policial, (ii) a falta de residência fixa ou identificação plena do indiciado; (iii) a existência de fundadas razões, de acordo com qualquer prova admitida na legislação penal, de autoria ou participação do indiciado em alguns crimes considerados graves. ${ }^{119}$

Observa-se que tal medida pode então servir tanto à proteção do processo, no caso dos incisos primeiro e segundo, quanto pode ser admitida em situações em que existam indícios contundentes do cometimento de crimes dolosos graves, este último devido ao abalo à ordem pública, evidenciado na gravidade do delito.

Segundo o artigo $2^{\circ}$ da mesma lei, trata-se de uma prisão exclusiva do inquérito policial, e que possui prazo de 5 dias, renovável uma única vez, por decisão judicial que denote a extrema e comprovada necessidade de adotála. ${ }^{120}$ Já o artigo $2^{\circ}, \S 4^{\circ}$, da Lei de Crimes Hediondos - Lei $n^{\circ}$ 8.072/1990, dispõe que, nos casos referentes a esta lei, o prazo é de 30 dias, renovável uma única vez. ${ }^{121}$

$\mathrm{O}$ artigo $2^{\circ}, \S 7^{\circ}$, da lei sobre prisão temporária também dispõe que, se não tiver sido decretada prisão preventiva, o preso deve ser posto em

\footnotetext{
${ }^{119}$ Artigo $1^{\circ}$, Lei n $\mathrm{n}^{\mathrm{0}}$ 7.960/1989. “Caberá prisão temporária: I - quando imprescindível para as investigações do inquérito policial; II - quando o indicado não tiver residência fixa ou não fornecer elementos necessários ao esclarecimento de sua identidade; III - quando houver fundadas razões, de acordo com qualquer prova admitida na legislação penal, de autoria ou participação do indiciado nos seguintes crimes: a) homicídio doloso; b) seqüestro ou cárcere privado; c) roubo; d) extorsão; e) extorsão mediante seqüestro; f) estupro e sua combinação; g) atentado violento ao pudor, e sua combinação; h) rapto violento; i) epidemia com resultado de morte; j) envenenamento de água potável ou substância alimentícia ou medicinal qualificado pela morte; 1) quadrilha ou bando, todos do Código Penal; m) genocídio, em qualquer de sua formas típicas; n) tráfico de drogas; o) crimes contra o sistema financeiro. p) crimes previstos na Lei de Terrorismo“.

${ }^{120}$ Artigo $2^{\circ}$, Lei $n^{\circ} 7.960 / 1989$. “A prisão temporária será decretada pelo Juiz, em face da representação da autoridade policial ou de requerimento do Ministério Público, e terá o prazo de 5 (cinco) dias, prorrogável por igual período em caso de extrema e comprovada necessidade. $\S 7^{\circ}$ Decorrido o prazo de cinco dias de detenção, o preso deverá ser posto imediatamente em liberdade, salvo se já tiver sido decretada sua prisão preventiva."

${ }^{121}$ Artigo $4^{\circ}$, Lei $n^{\circ} 8.072 / 1990$. “A prisão temporária, sobre a qual dispõe a Lei n ${ }^{\circ} 7.960$, de 21 de dezembro de 1989, nos crimes previstos neste artigo, terá o prazo de 30 (trinta) dias, prorrogável por igual período em caso de extrema e comprovada necessidade."
} 
liberdade imediatamente após findo o prazo de detenção, prescindindo portanto de determinação legal de soltura.

A prisão preventiva, por sua vez, pode ser decretada de ofício ou a requerimento, e obedece a dois conjuntos de requisitos. Em primeiro lugar, há requisitos positivos, começando-se pela avaliação da existência de prova do crime e indício suficiente de autoria. Trata-se de um requisito, em tese, mais rigoroso do que a justa causa necessária para o recebimento da denúncia, porque esta só requer indícios mínimos de autoria e materialidade - fumus comissi delicti.

Em seguida, verifica-se se configurada alguma das hipóteses constantes do artigo 312 do CPP, quais sejam a garantia (i) da conveniência da instrução criminal (preservar a colheita de provas de interferências do acusado), (ii) da aplicação da lei penal (evitar que o acusado se furte à aplicação da lei penal), (iii) da ordem pública e (iv) da ordem econômica.

De plano, denota-se a textura aberta dos conceitos de ordem pública e de ordem econômica, porque inexistem definições em lei, e as correntes doutrinárias não acordam na delimitação dos conceitos. Quanto à ordem pública, explica Theodomiro Dias Neto: ${ }^{122}$

\begin{abstract}
“A doutrina constitucional alemã - tradicionalmente orientada à ideia do Estado como centro único do poder, da política e do direito - passou a legitimar restrições às garantias individuais com base em um "direito fundamental à segurança" (Isensee, 1983), a ser protegido pelo Estado por intermédio do aparato penal. Ferrajoli (1978) diagnostica a deturpação da noção de garantismo, que de sistema de garantias da segurança do cidadão contra o arbítrio estatal converte-se em sistema de garantias de segurança do Estado."
\end{abstract}

${ }^{122}$ DIAS NETO, Theodomiro. Segurança urbana: o modelo da nova prevenção. São Paulo: RT, 2005, p. 93. apud ZACKESCKI, Cristina Maria; GOMES, Patrick Mariano. O que é ordem pública no sistema de justiça criminal brasileiro? Revista Brasileira de segurança pública, São Paulo, v. 10, n. 1, pp. 108-126, fev./mar. 2016, p. 93. 
Ao analisar os procedimentos judiciais no STF relativos à prisão preventiva para garantia da ordem pública, Cristina Zackescki observou que os inimigos da ordem são "aqueles que o poder político punitivo assim determina e opta por selecionar durante determinado período ou processo histórico." No período da redemocratização brasileira, o inimigo eleito seria o crime organizado: ${ }^{123}$

\begin{abstract}
"Como não se revisou a legislação de cunho autoritário, base das leis penais elaboradas durante o Estado Novo, a possibilidade legal de determinar a prisão de um cidadão ou cidadã com a justicativa de perigo ou risco à ordem pública acabou servindo para outros propósitos. A década de 1990, para o campo penal brasileiro, é marcada, sob a ótica legislativa, pela entrada em vigor da Lei no 8.072/90, que ficou conhecida como dos Crimes Hediondos, e da Lei no 9.034, de 3 de maio de 1995, a Lei das Organizações Criminosas. [...] É neste contexto de endurecimento da legislação penal que a jurisprudência do Supremo Tribunal Federal passa a ser mais abundante no tema da ordem pública e prisão cautelar. Com acentuada influência da legislação estrangeira autoritária, a entrada em vigor da Lei no 9.034, de 3 de maio de 1995, instituiu no País um novo inimigo: o "crime organizado". Combatê-lo virou palavra de ordem em qualquer discurso político, tanto da esquerda quanto da direita (KARAM, 1996)."
\end{abstract}

Do estudo da criminalização dos crimes econômicos, observa-se que a tutela da ordem pública já abarcaria diversos crimes econômicos realizados por meio das organizações criminosas atuantes nas esferas pública e privada. Infere-se, ainda, que a previsão legislativa atinente à garantia da ordem econômica promove uma seletividade reversa no combate à impunidade.

A criação de um atalho para o aprisionamento de um grupo seleto de criminosos é uma maneira de regredir na garantia (repise-se: constitucional) do mais sensível de seus direitos. Nesse diapasão, importante ressaltar que as medidas cautelares que privam o indivíduo da liberdade devem ser adotadas com tamanha parcimônia justamente porque pesam sobre o tempo de vida.

\footnotetext{
${ }^{123}$ ZACKESCKI, Cristina Maria; GOMES, Patrick Mariano. O que é ordem pública no sistema de justiça criminal brasileiro? Revista Brasileira de segurança pública, São Paulo, v. 10, n. 1, 108-126, fev./mar. 2016.
} 
O tempo é um recurso escasso ao ser humano; o indivíduo encarcerado nunca poderá reaver o tempo que passou dentro de uma jaula, afastado de sua casa, de sua família, de seus amigos, de seu trabalho - e envelhecendo. Ainda que, após, pudesse viver por mais tempo, ele já estaria mais velho, e teria perdido a oportunidade de compartilhar experiências com aqueles que lhe são caros. $\mathrm{O}$ direito à liberdade coincide, portanto, com o direito à vida.

$\mathrm{Na}$ realidade brasileira, o direito à liberdade também coincide como direito à dignidade da pessoa humana, tendo em vista a superlotação e sucateamento do sistema carcerário, reconhecidamente incapaz de garantir condições mínimas de saúde física e mental dos prisioneiros, que sofrem ainda com abusos dos agentes penitenciários.

O próprio STF declarou, no julgamento da ADPF no 347 em 2015, se tratar de um "estado de coisas inconstitucional que, segundo o Ministro Ricardo Lewandowski, trata-se de um quadro insuportável e permanente de violação de direitos fundamentais a exigir intervenção do Poder Judiciário de caráter estrutural e orçamentário. ${ }^{124}$

Para evitar abusos, a jurisprudência aplicava o dispositivo de forma moderada, entendendo que a prisão preventiva deveria ser adotada apenas quando demonstrado periculum in mora concreto, isto é, o perigo na demora da prestação jurisdicional caracterizada por uma ameaça concreta ao processo.

\footnotetext{
${ }^{124}$ Nesta oportunidade, o STF concedeu parcialmente cautelar solicitada na ADPF n ${ }^{\circ} 347$, que pede providências para a crise prisional do país, a fim de determinar aos juízes e tribunais que passem a realizar audiências de custódia, no prazo máximo de 90 dias, de modo a viabilizar o comparecimento do preso perante a autoridade judiciária em até 24 horas contadas do momento da prisão. Os ministros também entenderam que deve ser liberado, sem qualquer tipo de limitação, o saldo acumulado do Fundo Penitenciário Nacional para utilização na finalidade para a qual foi criado, proibindo a realização de novos contingenciamentos. Disponível em: <http://www.stf.jus.br/portal/cms/verNoticiaDetalhe.asp?idConteudo=299385>. Acesso em nov. 2018.
} 
Nesse sentido, seria necessário que o órgão acusatório apresentasse indícios de que o acusado estivesse tentando destruir provas, coagir testemunhas, ou de que estivesse tentando se furtar da aplicação da lei, desaparecendo ou, até mesmo, fugindo para outro país.

Já quanto à tutela das ordens pública e econômica, apontava-se o risco apenas quando o acusado desse indícios concretos de que voltaria a delinquir. Essa tese caiu por terra com a deflagração da Operação Lava-Jato, em 2014, em que se viu a necessidade da decretação de prisões cautelares de diversos agentes econômicos e políticos para desbaratar seus esquemas criminosos de natureza eminentemente econômica. ${ }^{125}$

Contudo, uma vez desbaratados os esquemas criminosos, muitas dessas prisões preventivas persistiram no decorrer das ações penais, apesar dos recorrentes pedidos das defesas pela liberdade, demonstrando que a prisão preventiva já teria satisfeito seus fins com, por exemplo, o afastamento dos acusados de suas funções públicas ou privadas.

A jurisprudência predominante veio adotando a gravidade concreta do delito, a magnitude do dano causado e a efetividade da lei penal (leia-se: combate à impunidade) como critérios justificadores da garantia das ordens pública e econômica, para manter os indivíduos sob a tutela do Estado, mesmo que a situação fática já tivesse mudado completamente.

Data máxima vênia, nem sempre os meios justificam os fins, especialmente se os meios podem gerar danos irreparáveis ao acusado. Devese evitar o esvaziamento do princípio da presunção de inocência por essa

\footnotetext{
125 A Operação Lava-Jato envolveu a repressão de diversos crimes econômicos, e.g.: organização criminosa, corrupção passiva e ativa, lavagem de ativos, desvio de verbas públicas, fraude ou supressão de licitações, cartel, tráfico de influência, evasão de divisas, operação de instituição financeira sem autorização, sonegação fiscal, falsidade eleitoral, etc.
} 
lógica que, ao invés de proteger os indivíduos do Estado - seus corpos, suas vidas, sua felicidade -, prioriza puni-los por crimes econômicos.

O caráter punitivo da prisão cautelar, em que pese rechaçado pela jurisprudência, se explica porque o sistema penitenciário brasileiro não faz qualquer diferenciação entre presos cautelares e em cumprimento (provisório ou não) de pena, em que pese os fundamentos diferenciados.

Justamente pela identidade substancial entre esses gravames, prevê-se o instituto da detração, estabelecendo a computação, na pena privativa de liberdade e na medida de segurança, do tempo de prisão provisória, de prisão administrativa ou internação, o que deve ser observado pelo juiz na sentença condenatória, para fins de determinação do regime inicial de cumprimento de pena, e pelo juiz da execução penal. ${ }^{126}$

Sob esse fundamento, o Supremo Tribunal Federal editou a Súmula ${ }^{\circ}$ 716, que permite até mesmo a progressão de regime de cumprimento de pena ou a aplicação imediata de regime menos severo nela determinada, antes do trânsito em julgado da sentença penal condenatória.

Em seguida, os requisitos negativos correspondem à verificação da (in)suficiência das medidas cautelares diversas à prisão, previstas nos artigos 319 e 320 do CPP, para resguardar o bem jurídico que se tutelaria, por meio do artigo 312 do Código.

\footnotetext{
${ }^{126}$ Artigo 42, CP. "Computam-se, na pena privativa de liberdade e na medida de segurança, o tempo de prisão provisória, no Brasil ou no estrangeiro, o de prisão administrativa e o de internação em qualquer dos estabelecimentos referidos no artigo anterior".

Artigo 387, CPP. “Art. 387. O juiz, ao proferir sentença condenatória: [...] $§ 2^{\circ} \mathrm{O}$ tempo de prisão provisória, de prisão administrativa ou de internação, no Brasil ou no estrangeiro, será computado para fins de determinação do regime inicial de pena privativa de liberdade".

Artigo 66, Lei no 7.210/1984 - LEP. “Art. 66. Compete ao Juiz da execução: [...] c) detração e remição da pena".
} 
À luz da presunção de inocência, a reiteração delitiva, em que pese na persecução de tão graves crimes, não deve ser presumida, cabendo à acusação requerer, sempre que possível, a conjugação das medidas substitutivas da prisão, que já impedem, por exemplo, que o acusado possa regressar ao seu local de trabalho, praticar certas atividades e comunicar-se com determinadas pessoas.

A prisão, por ser a medida mais gravosa, é portanto subsidiária às medidas substitutivas, que têm como características: (i) a preferibilidade frente à prisão; (ii) a variabilidade, podendo ser adotadas medidas mais ou menos rígidas, de acordo com a conveniência do juízo; e (iii) a cumulatividade, podendo-se optar pela adoção de mais diversas medidas conjugadas. ${ }^{127}$

Importante tratar, ainda, da condução coercitiva para prestação de depoimento perante a autoridade judicial, que consiste em uma medida cautelar temporária de restrição de liberdade do investigado, acusado ${ }^{128}$ ou testemunha, ${ }^{129}$ cujos requisitos foram sedimentados pelos tribunais superiores como sendo a intimação regular para comparecimento do ato, e a recusa injustificada de quem foi intimado e não compareceu. ${ }^{130}$

No julgamento das ADPFs $n^{\circ} 395$ e 444 pelo Supremo Tribunal Federal, em junho de 2018, foi declarada a não recepção da expressão "para

\footnotetext{
${ }^{127}$ Diverge-se, nesse ponto, da lição de Gustavo Badaró, no sentido de que as medidas substitutivas seriam na verdade alternativas à prisão, porque enquanto medidas menos graves poderiam ser adotadas ainda que não estivessem presentes os requisitos para a prisão. BADARÓ, Gustavo Henrique. Processo Penal - 5 ed. rev., atual e ampl. - São Paulo: Editora Revista dos Tribunais, 2017, p. 1083.

${ }^{128}$ Artigo 260, CPP. "Se o acusado não atender à intimação para o interrogatório, reconhecimento ou qualquer outro ato que, sem ele, não possa ser realizado, a autoridade poderá mandar conduzi-lo à sua presença".

${ }^{129}$ Artigo 218, CPP. "Se, regularmente intimada, a testemunha deixar de comparecer sem motivo justificado, o juiz poderá requisitar à autoridade policial a sua apresentação ou determinar seja conduzida por oficial de justiça, que poderá solicitar o auxílio da força pública".

130 RIBEIRO, Ivan M. O que é, afinal, condução coercitiva? Disponível em: $<$ https://canalcienciascriminais.jusbrasil.com.br/artigos/311252199/o-que-e-afinal-a-conducaocoercitiva>. Acesso em nov. 2018.
} 
o interrogatório" constante do artigo 260 do CPP, e declarar a incompatibilidade da condução coercitiva de investigados ou réus para com a Constituição Federal.

A maioria dos ministros entendeu que a condução coercitiva de investigados e acusados restringia de maneira irresponsável a liberdade da pessoa, uma vez que ela pode optar, no exercício de seu direito ao silêncio, a não comparecer perante a autoridade judicial para colaborar com o andamento do processo.

Nessa oportunidade, o Ministro Relator Gilmar Mendes sustentou que a condução coercitiva viola a presunção de inocência, e configura um meio para a "espetacularização” das investigações da Operação Lava-Jato. Disse, ainda, que não podem haver atalhos à persecução penal em um Estado de Direito que se pretende democrático: ${ }^{131}$

\begin{abstract}
“A restrição temporária da liberdade mediante condução sob custódia por forças policiais em vias públicas não é tratamento que normalmente possa ser aplicado a pessoas inocentes. O conduzido é claramente tratado como culpado. [...] Não há contraposição entre respeito aos direitos fundamentais e combate à corrupção. Combate à corrupção tem de ser feito nos termos estritos da lei. Quem defende um direito alternativo para combater a corrupção já não está no Estado de Direito. Mas é bom lembrar: assim se fez o nazi-facismo".
\end{abstract}

Já as medidas assecuratórias são aquelas que incidem sobre o patrimônio do investigado ou acusado, notadamente: (i) o sequestro de bens; (ii) o arresto prévio à hipoteca legal; (iii) a hipoteca legal; (iv) alienação antecipada de bens. Dentre esses instrumentos, opta-se pela adoção da medida que melhor atenda à finalidade pretendida, respeitando a ordem preferencial estabelecida pelo Código de Processo Civil. ${ }^{132}$

\footnotetext{
${ }^{131}$ STF, Plenário, ADPFs 395 e 444, Rel. Min. Gilmar Mendes, DJE 15.06.2018.

${ }^{132}$ A jurisprudência aplica subsidiariamente o artigo 835 do Código de Processo Civil quanto à ordem de preferência dos bens a serem constritos, preferindo-se os de maior liquidez, ou seja, valores a bens.
} 
Em que pese não atacarem a liberdade do acusado, Aury Lopes Jr. alerta que tais medidas são gravíssimas, porque esvaziam a presunção de inocência do acusado perante a sociedade, gerando um sentimento geral de desconfiança que prejudica de maneira irreversível seus negócios, in verbis: ${ }^{133}$

“. [...] não se pode desmerecer o fato de que o imputado já passa por uma situação difićlima, muitas vezes agravada pelo bizarro espetáculo midiático montado em torno das estrondosas operações policiais, que conduz a perda de clientes, fechamento de linhas de crédito, perda do emprego, enfim, um empobrecimento generalizado do réu, fruto do estigma gerado pela investigação e o processo penal. Nesse contexto, as medidas assecuratórias revestem-se de uma gravidade ainda maior, pois lhe impedem de dispor de seu patrimônio, seja para alienar ou dar em garantia, impossibilitando-o de ter liquidez para a própria subsistência. Ainda que no final do processo criminal seja absolvido ou que os bens indisponibilizados sejam em valor muito superior a eventual responsabilidade civil, em nível de endividamento e de penúria, é, muitas vezes, irreversível."

Enquanto o sequestro se aplica apenas aos produtos diretos ou indiretos da infração, porque pretende assegurar o perdimento de bens ilícitos, as demais modalidades podem incidir sobre bens de origem lícita, desvinculados do delito, eis que visam garantir o ressarcimento dos danos causados e de eventuais despesas judiciais.

Para mais, o caráter acessório de tais medidas frente à investigação ou processo criminal exige que a acusação fundamente o requerimento de constrição patrimonial cautelar com um lastro probatório mínimo, que demonstre o fumus comissi delicti (indícios mínimos de autoria e materialidade), em respeito à dimensão de juízo da presunção de inocência.

Badaró ensina que, em caso de sequestro, há que se trazer indícios veementes da proveniência ilícita dos bens visados ${ }^{134}$, bem como sua

\footnotetext{
${ }^{133}$ LOPES JR., Aury. Direito Processual Penal - 13 ed. - São Paulo: Saraiva, 2016, p. 734-736.

${ }^{134}$ Artigo 126, CPP. "Para a decretação do seqüestro, bastará a existência de indícios veementes da proveniência ilícita dos bens."
} 
referibilidade com o delito objeto da investigação ou ação penal. ${ }^{135}$ Já em relação às demais medidas, a acusação deve demonstrar a extensão do dano concreto causado para fins de estipulação proporcional - e não necessariamente identitária - do valor da constrição, em observância ao princípio da adstrição. ${ }^{136}$

Na persecução de crimes econômicos, em muito se argumenta que o perfil dos suspeitos já ensejaria a adoção de tais medidas, porque seriam eles os de maior conhecimento técnico sobre as formas de manipulação patrimonial e, assim, recaem suspeitas de ocultação ou dilapidação.

O impacto econômico causado pelo crime também acaba sendo levado em consideração, eis que própria soma a ser garantida, quando vultosa, acaba sendo um fator que gera um sentimento de urgência no juízo criminal.

Por conseguinte, nos casos em que os danos econômicos sejam altos e ultrapassem a totalidade do patrimônio do acusado, a jurisprudência predominante permite que a constrição incida sobre a integralidade de seu patrimônio, sem ao menos lhe resguardar verbas mínimas para subsistência, o que viola sua dignidade, especialmente quando responde ao processo em liberdade e não está sob a guarda do Estado.

Ademais, à luz do princípio constitucional da individualização da sanção penal, aplicável às medidas restritivas de direitos, há que se limitar o valor da constrição patrimonial à pessoa do acusado, evitando prejuízos a eventuais dependentes financeiros, como familiares e empregados, devido à eminente natureza alimentar dos valores a serem resguardados.

\footnotetext{
${ }^{135}$ BADARÓ, Gustavo Henrique. Processo Penal - 5 ed. rev., atual e ampl. - São Paulo: Editora Revista dos Tribunais, 2017, p. 1125-1152.

${ }^{136}$ LOPES JR., Aury. Direito Processual Penal - 13 ed. - São Paulo: Saraiva, 2016, p. 734-736.
} 
Considerando-se, em especial, o caráter cautelar das medidas assecuratórias, não se poderia priorizar a garantia patrimonial da prestação jurisdicional, em detrimento das necessidades básicas de pessoas cuja inocência nem mesmo é objeto de discussão.

O periculum in mora, por sua vez, restaria configurado por meio de indícios concretos de que o acusado estivesse tentando esconder os proventos do crime ou afastá-los de sua origem ilícita, ou ainda dilapidar seu patrimônio para se furtar de eventual ressarcimento ou custas processuais.

Uma vez realizada a constrição patrimonial, há de se observar a provisoriedade e a instrumentalidade da medida, de modo que ela somente deve se estender enquanto perdurarem seus fundamentos, o que requer uma constante reanálise sobre a necessidade, adequação e conveniência de sua continuidade, uma vez que o CPP não é taxativo quanto às hipóteses de levantamento da constrição. ${ }^{137}$

Para fins processuais, a busca e apreensão configura uma medida cautelar mista, porque a apreensão constitui medida assecuratória com a finalidade de produzir prova ou preservar direitos que precede a busca, que por sua vez, conforme ensina Cleunice Pitombo, se trata de um ato de procura de pessoa ou coisa que pode ostentar-se na revista ou no varejamento. ${ }^{138}$

A busca e apreensão domiciliar pode ser realizada tanto na residência do acusado quanto no local em que exerça profissão ou atividade, ${ }^{139}$ e levar à apreensão de qualquer elemento de convicção pertinente à elucidação dos

\footnotetext{
${ }^{137}$ Artigo 141, CPP. "OO arresto será levantado ou cancelada a hipoteca, se, por sentença irrecorrível, o réu for absolvido ou julgada extinta a punibilidade."

${ }^{138}$ PITOMBO, Cleunice A. Valentim Bastos. Da busca e apreensão no processo penal, p. 96. apud BADARÓ, Gustavo Henrique. Processo Penal - 5 ed. rev., atual e ampl. - São Paulo: Editora Revista dos Tribunais, 2017, p. 502-511.

${ }^{139}$ Para Badaró, o conceito de domicílio deve ser amplo, abarcando, conforme os artigos 246 do CPP e $150, \S 4^{\circ}$ do CP: (i) qualquer compartimento habitado, (ii) aposento ocupado de habitação coletiva; (iii) compartimento não aberto ao público, onde alguém exerce profissão ou atividade.
} 
fatos, como por exemplo os objetos necessários à prova de infração e as cartas abertas ou não.

Em que pese parte da doutrina considerar que a Constituição Federal teria revogado o artigo $240, \S 1^{\circ}$, f, do CPP, no que permite o devassamento de cartas fechadas, Nucci sustenta que, se a presunção de inocência não tem o condão de impedir a prisão cautelar no ordenamento jurídico pátrio, não pode obstar a abertura de cartas nas investigações criminais. ${ }^{140}$

Em relação às formalidades para a diligência, tem-se que deve ser realizada por determinação judicial e durante o dia, ${ }^{141}$ período este entre o amanhecer e o anoitecer, exceto se houver consentimento expresso e efetivo do morador. Nucci entende como dia o período entre o amanhecer e o anoitecer, sem horários prefixados. ${ }^{142}$

O artigo $240, \S 1^{\circ}$ e $\S 2^{\circ}$, e 244 do CPP dispõe sobre os requisitos para a buscas domiciliar e pessoal. Para a primeira modalidade, requer-se "fundadas razões," o que confere uma generalidade perigosa ao dispositivo. Já para a segunda, basta-se "fundada suspeita" da ocultação de objetos que formem a materialidade do crime, o que denota uma subjetividade indesejada, porque pode afastar a necessidade de mandado judicial.

Nesse ponto, Badaró sugere que o CPP deveria ter exigido indícios ou fundados indícios que ensejassem a prescindibilidade do mandado judicial para revista pessoal, mas atesta que o Supremo Tribunal Federal já se manifestou à respeito, determinando que não bastam parâmetros unicamente

\footnotetext{
${ }^{140}$ NUCCI, Guilherme de Souza. Manual de processo penal e execução penal: 14 ed. rev., atual. e ampl. - Rio de Janeiro: Forense, 2017, p. 485-489.

${ }^{141}$ Artigo $5^{\circ}$, XI, CRFB. " [...] a casa é asilo inviolável do indivíduo, ninguém nela podendo penetrar sem consentimento do morador, salvo em caso de flagrante delito ou desastre, ou para prestar socorro, ou, durante o dia, por determinação judicial";

142 NUCCI, Guilherme de Souza. Manual de processo penal e execução penal: 14 ed. rev., atual. e ampl. - Rio de Janeiro: Forense, 2017, p. 493.
} 
subjetivos para essa "fundada suspeita", em face do constrangimento que causa à pessoa. ${ }^{143}$

Outro aspecto relevante é a duração da apreensão, junto à autoridade policial, dos objetos de trabalho obtidos em resultado das buscas. Questionase a necessidade da continuidade do acautelamento de, por exemplo, documentos, celulares e computadores, uma vez já realizadas as cópias e espelhamentos pertinentes à produção probatória, quando estes são importantes para o exercício de atividades empresariais, negociais, etc.

Mais uma vez, se a presunção de inocência não admite a presunção de reiteração delitiva, também caberia à acusação apresentar indícios contundentes de que esses materiais serviriam à continuidade de práticas criminosas, o que em muito ficaria obstado pela adoção das supracitadas medidas cautelares de prisão ou substitutivas.

\section{III.2.2. Denúncia genérica}

Conforme já abordado, a presunção de inocência enquanto regra de juízo confere à acusação o ônus de argumentação e de prova no processo penal. Em termos de denúncia, tem-se que, sob pena de rejeição por inépcia formal, a acusação deve trazer a exposição de todas as circunstâncias do fato criminoso, o que, em caso de concurso de agentes, inclui a descrição das condutas criminosas de maneira individualizada.

Apesar de essa lógica se aplicar aos crimes comuns de maneira inequívoca, ela foi objeto de discussão quanto aos crimes econômicos, diante das dificuldades percebidas em fase de investigação preliminar, em razão da

\footnotetext{
${ }^{143}$ BADARÓ, Gustavo Henrique. Processo Penal - 5 ed. rev., atual e ampl. - São Paulo: Editora Revista dos Tribunais, 2017, p. 502-511.
} 
gravidade e complexidade objetiva (contexto fático) e subjetiva (numerosidade de agentes) do fato. ${ }^{144}$

Passou-se a defender que a denúncia não precisaria descrever a conduta de forma individualizada, de modo que a autoria pudesse ser verificada quando o indivíduo detivesse o poder de decisão e, assim, o domínio final do fato.

Sob estes argumentos, parte da doutrina e jurisprudência passaram a admitir flexibilização do artigo 41 do CPP para abarcar a denúncia genérica, sem que se individualizasse a conduta de cada réu, desde que fosse assegurada ao réu a possibilidade de fazer uma defesa razoável.

Nesse sentido, Eugênio Pacelli sustenta que não haveria dificuldade para o exercício de defesa porque não se trataria de hipótese de acusação genérica, mas de denúncia geral, que meramente englobaria todos aqueles responsáveis pelo ato ilícito praticado, como por exemplo os sócios de uma empresa que, no exercício de gerência, realizaram fato típico. ${ }^{145}$

Sustenta-se que a acusação não estaria obrigada a individualizar as condutas criminosas, bastando, para a denúncia, indícios suficientes da ocorrência de um crime, somados à existência de, por exemplo, um estatuto social em que se atribua ao sócio ou administrador os poderes necessários à realização da conduta criminosa. Caberia, portanto, aos acusados demonstrarem sua inocência e apontarem os eventuais responsáveis.

Entretanto, outra parte da doutrina adota uma postura garantista, e sustenta que o processo penal já é, de per si, um pesado fardo na vida do acusado, sob os aspectos psicológico, social e profissional, e por isso mesmo

\footnotetext{
${ }^{144}$ LOPES JR., Aury. Direito Processual Penal - 13 ed. - São Paulo: Saraiva, 2016, p. 237.

${ }^{145}$ OLIVEIRA, Eugênio Pacelli de. Curso de Processo Penal - 20. ed. rev., atual. São Paulo: Atlas, 2016.
} 
a regra do artigo 41 do CPP confere ao órgão acusador o dever de fundamentação, o que garante que terá parcimônia em sua atuação acusando apenas quando julgar presente a justa causa, e apresentando razões de fato e de direito bem delineadas.

Como já dizia Carrara, “o processo criminal é o que há de mais sério no mundo“, o que lhe obriga ter clareza, certeza, positivação, ou seja, nada de suposto, duvidoso, análogo, paralelo ou ampliável. A acusação deve ser, portanto, "positivamente articulada [...] sobre a precisão morfológica legal", para que a defesa seja possivelmente segura. ${ }^{146}$

Nesse diapasão, a denúncia genérica seria uma flagrante tentativa de cerceamento de defesa, por meio da inversão do ônus da prova, e da própria lógica processual, o que não se permite pela regra de juízo decorrente da presunção de inocência.

É que, para que o processo possa transcorrer validamente, é necessário que a petição inicial permita que o indivíduo entenda qual a tese acusatória, especialmente quanto à descrição dos fatos, ${ }^{147}$ e que sua defesa técnica possa então elaborar a tese defensiva. Preza-se pela segurança jurídica, e evita-se a surpresa.

De acordo com João Mestieri, ainda que se trate de crimes econômicos, se for impossível ao órgão acusatório previsar os fatos e atribuílos - claramente - as condutas individualizadas, não poderá ele aparelhar uma acusação, pois sua admissão impediria que o réu conhecesse as

\footnotetext{
${ }^{146}$ CARRARA, Francesco. apud ROMEIRO NETO, João. O Direito penal militar nos casos concretos. Rio de Janeiro: José Konfino: 1966.

${ }^{147}$ Repise-se que a classificação do crime é importante também, mas a classificação errônea não torna a denúncia inepta. $\mathrm{O}$ art. $383 \mathrm{CPP}$ prevê que o réu está se defendendo do fato e não da classificação jurídica colocada na acusação, mas se o juízo reputar que os fatos são outros, deve determinar o aditamento da denúncia, a teor do art 384, CPP. Assim, só será inepta quando não expor os fatos.
} 
imputações em sua totalidade, e assim se violaria o princípio da ampla defesa. ${ }^{148}$

Compartilhando desse entendimento, Aury Lopes Jr. defende que, nem nos crimes econômicos mais complexos, pode-se negar ao acusado a garantia processual de individualização da conduta que lhe foi imputada, relativizando o ônus argumentativo e probatório da acusação. ${ }^{149}$

\begin{abstract}
"Mas o problema mais grave situa-se nos casos penais complexos, que envolvem concurso de pessoas e de delitos, principalmente nos chamados crimes econômicos. Diante da natural dificuldade em circunscrever adequadamente qual ou quais condutas cada um dos agentes, de forma individualizada, praticou, recorrem alguns acusadores à chamada denúncia genérica. A nosso juízo é inadmissível, mesmo nos crimes mais complexos. Incumbe à investigação preliminar esclarecer (ainda que em grau de verossimilhança) o fato delitivo, buscando individualizar as condutas de modo que a denúncia seja determinada e certa, no sentido da individualização das responsabilidades penais a serem apuradas no processo".
\end{abstract}

O mesmo seria sustentado por Elmir Duclerc, ao concluir: ${ }^{150}$

. [...] acima das exigências do princípio da obrigatoriedade, está, sem dúvida, o princípio da ampla defesa, a impedir, segundo pensamos, que qualquer pessoa seja acusada senão por fatos certos, determinados e descritos de forma clara e objetiva pelo acusado".

Ademais, tanto Aury Lopes Jr. quanto Guilherme Nucci sustentam que, nem mesmo em casos complexos e excepcionais, poderia-se admitir que a acusação ofertasse denúncia alternativa, que traz duas versões diferentes para o mesmo fato, contra o mesmo réu, deixando que uma delas prevaleça ao final. Cairia por terra, assim, as chances de ampla defesa do acusado, porquanto neutralizada a capacidade do defensor de produzir uma tese defensiva minimamente eficaz.

\footnotetext{
${ }^{148}$ MESTIERI, João. Manual de Direito Penal. Rio de Janeiro: Editora Imprenta, 1999.

${ }^{149}$ LOPES JR., Aury. Direito Processual Penal - 13 ed. - São Paulo: Saraiva, 2016, p. 237.

${ }^{150}$ DUCLERC, Elmir. Curso de Direito Processual Penal. apud LOPES JR., Aury. Direito Processual Penal - 13 ed. - São Paulo: Saraiva, 2016, p. 237.
} 
Nucci sustenta que a melhor maneira de se sopesar as demandas punitiva e garantista seria a admissão da denúncia genérica, ou seja, que não se delimite com clareza as condutas de cada um dos acusados, desde que o órgão acusatório traga provas de que todos os denunciados estão envolvidos no suposto delito. Veja-se: ${ }^{151}$

"Incide a hipótese de denúncia genérica nos casos de crimes econômicofinanceiros, quando o Estado-acusação, sem saber exatamente quais dos responsáveis pela empresa cometeu o delito, denuncia todos os dirigentes, bastando que estejam constando no contrato social. Essa peça acusatória é inepta, pois inexiste possibilidade de se acusar indistintamente pessoas, sem prova segura de serem autoras da infração penal. [...] Se vedássemos o ingresso da ação penal somente porque a conduta de cada coautor (ou partícipe) não ficou nitidamente demonstrada, haveria impunidade, situação indesejável. Diante disso, acolhe-se a denúncia genérica quando há provas contra todos os acusados, embora não se saiba, com precisão, qual a conduta de cada um".

Nessa lógica, a jurisprudência sedimentou entendimento de que, embora prescindível a individualização da conduta do réu, seria ainda essencial a demonstração de um vínculo causal entre a conduta do acusado e o crime cometido, sob pena de inviabilizar sua defesa, o que importaria na rejeição da denúncia por inépcia, ou trancamento da ação penal. ${ }^{152}$

Recentemente, o STJ vem adotando uma postura moderada, admitindo a denúncia geral que, segundo a Ministra Maria Thereza de Assis Moura, seria aquela que, “em crimes societários, descreve, mesmo minimamente, a conduta imputada aos denunciados, permitindo-lhes o pleno exercício da ampla defesa e do contraditório. ${ }^{\cdot 153}$

\footnotetext{
${ }^{151}$ NUCCI, Guilherme de Souza. Manual de processo penal e execução penal: 14 ed. rev., atual. e ampl. - Rio de Janeiro: Forense, 2017.

${ }^{152}$ Precedente-paradigma: STF, $1^{\text {a }}$ Turma, $\mathrm{HC}^{\circ}$ 95.156/AM, Rel. Min. Ricardo Lewandowski, DJE 20.11.2009.

${ }^{153}$ Precedente-paradigma: STJ, $6^{a}$ Turma, AgRg no REsp n ${ }^{\circ}$ 1455581/PR, Rel. Min. Maria Thereza de Assis Moura, j, 17.12.2015. No mesmo sentido: "Nos chamados crimes de autoria coletiva, embora a vestibular acusatória não possa ser de todo genérica, é válida quando, apesar de não descrever minuciosamente as atuações individuais dos acusados, demonstra um liame entre o seu agir e a suposta prática delituosa, estabelecendo a plausibilidade da imputação e possibilitando o exercício da ampla defesa”. (STJ, 6a Turma, RHC nº 60977/SP, Rel. Min. Jorge Mussi, j. 17.12.2015)
} 


\section{III.2.3. Execução provisória da pena}

No plano constitucional, o princípio da presunção de inocência é extraído do artigo 5 , LVII, da Constituição Federal de 1988, o qual prevê a regra de que ninguém será considerado culpado antes do trânsito em julgado de sentença penal condenatória.

Antes do advento da Carta Magna de 1988, o ordenamento jurídico admitia a prisão em execução provisória da pena, ou seja, quando pendente recurso em face da sentença condenatória penal, tendo em vista que o artigo 637 do CPP, que estabelecia apenas o efeito devolutivo, mas não suspensivo, dos recursos extraordinários. ${ }^{154}$

De acordo com a praxe dos tribunais, o marco inicial para a execução penal se dava (i) com o trânsito em julgado em primeiro grau, quando não era interposto recurso de apelação, ou (ii) com o proferimento de acórdão condenatório em segunda instância, uma vez que o recurso de apelação era o primeiro, e único, com efeito suspensivo, em regra.

Diversos artigos da Lei de Execuções Penais, promulgada em meio ao período de redemocratização do país, já antecipavam o que viria a ser a nova regra constitucional, ao determinar em diversos dispositivos que a pena privativa de liberdade deveria ser executada a partir do trânsito em julgado da sentença condenatória.

Após duas décadas de acaloradas discussões, veio o julgamento do HC $n^{\circ}$ 84.078/SP em 2009, por meio do qual o STF firmou a tese de que a prisão em execução antecipada da pena contraria o artigo $5^{\circ}$, LVII, da Constituição

\footnotetext{
${ }^{154}$ De fato, ainda era possível se requerer o provimento de efeito suspensivo quando o recurso chegasse ao tribunal superior.
} 
Federal de 1988, o qual prevê que ninguém será considerado culpado antes do trânsito em julgado de sentença penal condenatória.

Consolidou-se, assim, que o artigo 637 do CPP não subsistiu, temporal e materialmente, à Lei de Execuções Penais de 1984 e à Constituição Federal de 1988, e que a prisão cautelar seria a única cabível antes do trânsito em julgado da condenação, uma vez que visa tutelar o processo penal e, assim, a prestação jurisdicional.

O Ministro Relator Eros Grau explicou que a antecipação da execução penal não se daria em prol do processo penal, mas da conveniência dos magistrados dos tribunais superiores, que se veriam desafogados de trabalho, sendo que a liberdade individual seria um preço alto demais a se pagar.

Nesse momento, fez-se uma escolha democrática: deixar que respondessem em liberdade os criminosos de fato, para resguardar a liberdade dos inocentes, cuja inocência poderia ser verificada, por vezes, apenas quando do julgamento do caso perante as instâncias superiores.

O Relator ainda explicou que a jurisdição dos tribunais superiores se restringe às matérias prequestionadas, e pertinentes aos seus pretextos - ao STJ, a guarda da legislação federal, e ao STF, a guarda da Constituição. Mas uma vez admitidos os recursos extraordinários, a jurisdição dos tribunais superiores se abrem para o exame de matérias de ordem pública, como é a matéria constitucional, que pode inclusive ser conhecida de ofício.

Em que pese não poderem revolver questões de fato, os tribunais superiores podem visitar questões constitucionais, que são incidentais, inclusive ao processo penal. Vê-se então condenações que, ao atingirem os 
tribunais superiores, acabaram sendo anuladas por se basearem, e.g., em provas ilícitas, que contaminaram a convicção do juízo. ${ }^{155}$

Nessa oportunidade, o Ministro Gilmar Mendes ainda ressaltou que morosidade da prestação jurisdicional não só contribui para um contexto de impunidade, mas para uma outra realidade muito mais urgente a ser combatida: a de superlotação do sistema carcerário brasileiro.

Menos de 7 anos após a consolidação desse entendimento, em 2016, o STF revisitou o tema no julgamento do $\mathrm{HC} \mathrm{n}^{\mathrm{o}}$ 126.292/SP, e decidiu regredir ao entendimento anterior à redemocratização do país, permitindo-se a execução provisória da pena, desde que proferido acórdão condenatório por colegiado de tribunal ordinário.

O Ministro Relator Teori Zavascki argumentou que a revisão criminal por colegiado, no âmbito das instâncias ordinárias, promove duplo grau de jurisdição suficiente para garantir o núcleo essencial da presunção de inocência, eis que exaure o exame sobre os fatos e provas da causa.

Em seguida, retornou ao já refutado argumento de que a cognição estrita à matéria de direito é inerente ao âmbito das instâncias extraordinárias e acarreta na "relativização e até mesmo a própria inversão, para o caso concreto, do princípio da presunção de inocência até então observado", não

\footnotetext{
${ }^{155}$ A ilicitude da prova se dá por irregularidade na obtenção da prova, e constitui hipótese de nulidade absoluta da sentença condenatória que nela se basear, por força da garantia de licitude da prova prevista no artigo $5^{\circ}$, LVI da CRFB, e das limitações constitucionais do direito à intimidade, inviolabilidade do domicílio e da inviolabilidade de comunicações, respectivamente previstas no artigo $5^{\circ}, \mathrm{X}, \mathrm{XI}$ e XII da CRFB. De acordo com o artigo 157 do CPP, trata-se de uma prova inadmissível, que deve ser desentranhada dos autos. Há enorme discussão sobre os limites da contaminação da prova ilícita nas demais - se contamina apenas aquelas necessariamente decorrentes, ou também aquelas provas que se foram obtidas pelo mesmo meio de prova. É o caso de uma cautelar deferida de interceptação telefônica que gravou inclusive períodos não requeridos formalmente - a jurisprudência diverge se deve-se desentranhar dos autos todas as gravações obtidas, ou apenas a parte gravada no período indevido.
} 
ensejando efeito suspensivo aos recursos extraordinários, assim como constante no artigo $637 \mathrm{CPP}$.

É que, para Zavascki, o Supremo Tribunal Federal, na qualidade de corte constitucional, e à luz dos requisitos de repercussão geral traçados pela EC $n^{\circ} 45 / 2004$, deveria ser adstrito aos recursos relativos a questões transcendentes ao interesse subjetivo da parte.

Ademais, para o Relator, a experiência internacional demonstraria que o sistema constitucional brasileiro é uma verdadeira "jabuticaba," sendo desnecessário o referendo condenatório da corte constitucional de qualquer outro país para a execução da pena privativa de liberdade. Nesse sentido, os tribunais superiores teriam se tornado instâncias revisoras, desvirtuadas de suas funções constitucionais.

Reacendeu, ainda, os argumentos de conveniência dos magistrados dos tribunais superiores, ao aduzir que a consolidação jurisprudencial no sentido de negar executividade às condenações antes do trânsito em julgado gerava a interposição excessiva e abusiva de recursos com intuito protelatório, que atrapalhavam o trabalho das cortes superiores.

A seu ver, entre 2009 e 2016, a vedação da execução provisória teria criado óbice à efetividade jurisdicional, porque o último marco interruptivo do prazo prescricional antes do início do cumprimento da pena é a publicação da sentença ou acórdão recorríveis. Para tanto, exemplificou casos de extinção da punibilidade em virtude da prescrição da pretensão punitiva após sucessivos recursos interpostos pela defesa.

O Relator sustentou, assim, que conferir apenas efeito devolutivo aos recursos especial e extraordinário não desampararia o acusado, eis que não impediria o deferimento de efeito suspensivo a casos excepcionais e a 
impetração de habeas corpus, coibindo assim eventuais distorções e abusos cometidos nas instâncias ordinárias.

Em complementação, o Ministro Luís Roberto Barroso teceu algumas considerações relevantes em seu voto, pregando o afastamento da literalidade do art. 5º, LVII, da Constituição Federal à luz de uma interpretação sistemática.

O magistrado salientou a necessidade de diferenciação entre o condicionamento da prisão e da culpabilidade, ${ }^{156}$ uma vez que o esgotamento das instâncias ordinárias importaria em uma exigência de ordem pública à execução da pena, haja vista a manutenção da credibilidade do judiciário e do sistema penal.

Ademais, a presunção de inocência seria um princípio constitucional e não regra, portanto não absoluta, o que permitiria a dosagem de sua incidência, valendo-se do princípio da proporcionalidade para ponderação dos princípios constitucionais colidentes, em especial frente ao interesse constitucional na efetividade da lei penal. ${ }^{157}$ Seria cabível, então, reverter a lógica da presunção de inocência, permitindo o encarceramento de inocentes para garantir a punição dos criminosos.

Ainda no embate técnico, sustentou que, no decorrer da investigação e processamento criminal, haveria uma gradativa mitigação da presunção de inocência, em especial uma redução significativa após condenação em segundo grau de jurisdição, haja vista o encerramento da apuração de fatos, provas e a confirmação da responsabilidade penal.

\footnotetext{
${ }^{156}$ Para Barroso, a prisão seria ordem escrita e fundamentada de autoridade judiciária competente, independentemente de recorribilidade, enquanto a culpabilidade é que se constituiria trânsito em julgado da sentença penal condenatória.

${ }^{157}$ A sua nova interpretação, adotada em nível constitucional (art. 5o, LVII CRFB/1988), incidiria hierarquicamente sobre a legislação ordinária (art. 283 CPP/1941).
} 
Em seguida, argumentou que, em virtude de alteração na compreensão da realidade social, teria ocorrido uma nova mutação constitucional para reverter as consequências negativas advindas do julgamento ocorrido em 2009, mostrando-se proteção insatisfatória aos demais princípios constitucionais tutelados pelo direito penal.

A seletividade do sistema penal teria se agravado, segundo o Ministro, porque a vedação à execução provisória aproveitava apenas aos réus com recursos para contratar advogados a defendê-los em sucessivos recursos, não tendo a Defensoria Pública estrutura para bancar a "procrastinação." Assim, a superlotação de cadeias se daria exatamente por aqueles que não têm condições de manter advogado interpondo recursos.

Nesse momento, Barroso deixou claro que o retrocesso da garantia de presunção de inocência visava os réus dotados de poder econômico suficiente para "bancar" advogados que ficassem, ad aeternum, apresentando novos recursos para proteger seus clientes da prisão-pena, que em geral estaria reservada aos assistidos da Defensoria Pública.

Data vênia, tal argumento não se sustenta, porquanto (i) não há reprovabilidade à interposição de recursos, uma vez que está legalmente e regimentalmente estabelecido, e constitui exercício regular de direito, e (ii) não se pode culpar a defesa que recorre pelo retardamento do trânsito em julgado, quando em verdade é a própria morosidade do Judiciário.

Ademais, nessa tentativa de reduzir a impunidade das classes sociais mais altas, abre-se um gravíssimo precedente para a relativização da presunção de inocência no processo e execução penal, que ampliou os poderes punitivos do Estado não apenas frente aos criminosos de colarinho branco, mas a toda a população brasileira. 
Também em consequência do modelo instituído em 2009, Barroso aponta que os magistrados em instâncias ordinárias passaram a cometer abusos na utilização da prisão preventiva, a fim de evitar que a punição nunca chegasse a ocorrer. Trata-se de uma inversão da ordem lógica do processo penal (punir, selar a culpa, e somente após executar a pena), para punir desde início, para garantir a prestação jurisdicional.

Já a perda de credibilidade do sistema penal se daria, para ele, em função de casos de prescrição da pretensão punitiva e de distanciamento temporal entre a prática do delito e a punição, criando sensação geral de impunidade e comprometendo os objetivos punitivos de prevenção e a segurança jurídica. ${ }^{158}$

Tal clamor social pelo combate à impunidade foi inflamado mormente com a deflagração da Operação Lava-Jato e decorrentes, que possuem repercussão nacional por meio dos canais de comunicação, e pelo engajamento de movimentos sociais contrários à tradição de imoralidade das classes política e econômica do país.

Para o Ministro, a efetividade jurisdicional possuiria um potencial republicano e igualitário, eis que desestimularia a determinação de prisões preventivas e desafogaria o sistema penitenciário. Seria necessário atender a demanda social por um direito penal sério, evitando as prescrições punitivas em razão do sistema moroso, e gerando um sentimento social de eficácia da lei penal.

Olvida, assim, das lições mais básicas sobre a separação de poderes: ao Legislativo, cabe tipificar as condutas proibidas; ao Executivo, cabe

\footnotetext{
${ }^{158}$ Barroso sustenta que uma prestação jurisdicional muito demorada esvaziaria as funções da pena de prevenção especial (imediata, desestimulando reiteração delitiva pelo agente) e geral (mediata, desestimulando os membros da sociedade), e chegaria a ser descabida depois de tantos anos, porque surpreenderia uma pessoa que já teria mudado com o tempo em muitos aspectos.
} 
executar a punição; ao Judiciário, cabe garantir que entre a criminalização de uma conduta e a execução da punição, haja um processo penal que se rege pela presunção da inocência do acusado, garantindo-lhe ampla defesa.

O Poder Judiciário é, portanto, o poder que legitima a pretensão punitiva do Estado Democrático, na medida em que garante ao acusado seus direitos e garantias individuais, em todas as etapas do processo. Não cabe a este poder ouvir os anseios punitivistas da população, mas a proteger o acusado da opinião pública.

Em que pese se focar na proteção dos direitos e garantias de natureza individual, é cediço que existe um interesse público primário na tutela individual, ${ }^{159}$ porque garantir a presunção de inocência de um significa limitar, frente a todos, o poder punitivo do Estado a padrões democráticos.

Dessa forma, ao defender uma suposta moralização do sistema penal por meio da relativização das garantias individuais, em verdade o Supremo se afasta de suas funções democráticas, e abre mão de seu papel mais importante: de " última trincheira da cidadania." $" 160$

Na divergência, o Ministro Celso de Mello proferiu voto pela manutenção do entendimento firmado em 2009, sob alguns argumentos de relevância. Em primeiro lugar, registrou que a presunção de inocência seria um direito-garantia, produto de desenvolvimento político jurídico de séculos, e “representa uma notável conquista histórica dos cidadãos em sua permanente luta contra a opressão do Estado e o abuso de poder. .

\footnotetext{
159 "Os interesse públicos primários são os interesses diretos do povo, os interesses gerais imediatos. Já os interesses públicos secundários são os interesses imediatos do Estado na qualidade de pessoa jurídica, titular de direitos e obrigações." ALEXANDRINO, Marcelo Alexandrino. PAULO, Vicente. Direito Administrativo Descomplicado. $18^{\mathrm{a}}$ ed. Revista e atualizada, Rio de Janeiro: Forense; São Paulo: Método, 2010. p. 187.

160 Essa expressão é amplamente utilizada pelo Ministro Celso de Mello. Disponível em: $<$ https://www.redebrasilatual.com.br/politica/2016/03/supremo-e-a-ultima-trincheira-da-cidadaniadiz-marco-aurelio-3193.html>. Acesso em nov. 2018.
} 
Em seguida, apontou que a presunção de inocência é reconhecida em documentos internacionais como valor fundamental, exigência básica de respeito à dignidade da pessoa humana, e ainda base da democracia, uma vez que a natureza do regime estaria intimamente relacionada à proteção conferida à presunção de inocência. ${ }^{161}$

Assim, se outros países optassem por uma proteção menos intensa, o que nem sempre é verdade, não caberia criticar o modelo constitucional brasileiro por sua suposta singularidade, em que a presunção de inocência teria sido elevada a um primado.

Nessa linha, o Ministro sustentou a insuperabilidade da vedação constitucional da presunção de inocência como fator de proteção e requisito de legitimação da própria persecução e execução penal, especialmente ao se disciplinar limitações à prerrogativa jurídica da liberdade individual, que não podem ser impostas com base em suposições ou juízos prematuros.

Ressaltou, ainda, que a permissibilidade da aplicação de prisões cautelares se dá em função da preservação do interesse da coletividade no processo penal regular, mas não em detrimento dela, como de fato ocorreria com a mitigação do seu direito de recorrer em liberdade.

Quanto ao argumento do suposto esvaziamento progressivo da presunção de inocência, à medida em que se sucedem os graus de jurisdição com confirmação de culpa, Celso de Mello respondeu que o princípio da ampla defesa demanda justamente a manutenção do estado de inocência em todos os graus, para que seja efetivada sua pretendida amplitude.

\footnotetext{
${ }^{161}$ Celso de Mello exemplifica a experiência das escolas italianas dos séculos XIX e XX, bem como a experiência do Brasil durante o Estado Novo, regime autoritário, em que se impunha ao acusado o ônus de comprovar que não era culpado.
} 
O magistrado trouxe ainda dados alarmantes, de que houve o provimento integral ou parcial de 28,5\% dos recursos extraordinários criminais interpostos perante o Supremo Tribunal Federal entre os anos de 2006 e 2016, ${ }^{162}$ ou seja, quase um terço das decisões criminais oriundas das instâncias inferiores foram reformados pela mais alta corte.

O Ministro Marco Aurélio, por sua vez, levantou que a presunção de inocência constitui a base do garantismo penal estabelecido pela Constituição de 1988, e que a literalidade e clareza do dispositivo veda a execução provisória da pena, e exige a autocontenção do Judiciário frente a possíveis interpretações em sentido contrário.

Isso também se justificaria pela própria separação de poderes, eis que, a teor do artigo 60 da Constituição, nem mesmo um projeto de emenda constitucional do Legislativo poderia discutir a matéria, tendo em vista que o artigo $5^{\circ}$, LVII, da CRFB consiste em cláusula pétrea na defesa dos direitos e garantias individuais.

Ressaltou, ainda, que enquanto a execução provisória no direito civil, em que há possibilidade do retorno ao status quo ante, o mesmo não ocorre na esfera penal, porque não há como devolver a liberdade ao indivíduo referente ao tempo que deveria ter permanecido solto. ${ }^{163}$

Desde a guinada do Supremo Tribunal Federal pela admissibilidade da execução provisória da pena, o tema passou por rediscussões em sede de habeas corpus, mas o novo entendimento se manteve. Aguarda-se, ainda, o julgamento das $\mathrm{ADCs} \mathrm{n}^{\circ} 43$ e 44 pelo plenário da Corte, cuja liminar, que

\footnotetext{
${ }^{162}$ Foram providos integralmente $25,2 \%$ dos recursos supramencionados, e parcialmente 3,3\% destes, que somados chegam ao significativo percentual de $28,5 \%$ de recursos.

${ }^{163} \mathrm{O}$ mesmo argumento foi levantado pelo Ministro Ricardo Lewandowski, ao dizer que, ainda que o Estado possa indenizar o preso inocente, não há dinheiro que compre o tempo que a pessoa passou presa e em condições degradantes.
} 
pretendia suspender a execução antecipada da pena de todos os acórdãos prolatados em segunda instância, foi indeferida ainda em 2016. ${ }^{164}$

A matéria se encontra, portanto, eivada de insegurança jurídica, mas demonstra com clareza o impacto gerado pelas ondas punitivas de combate à impunidade dos crimes econômicos, em detrimento das garantias individuais de todos os brasileiros, que perderam a proteção dos tribunais superiores contra o crescente punitivismo estatal.

${ }^{164}$ Disponível em: 〈http://www.stf.jus.br/portal/cms/verNoticiaDetalhe.asp?idConteudo=326754〉. Acesso em nov. 2018. 


\section{Conclusão}

Decerto, o combate aos crimes econômicos é de extremo interesse social, tendo em vista os enormes impactos que podem causar ao desenvolvimento socioeconômico do país, nos âmbitos público e privado. Para tanto, deve-se fortalecer e aprimorar, sempre que possível, seus mecanismos jurídicos.

A tutela da ordem econômica deve ocorrer, primeiramente, na seara do direito administrativo, por meio das autarquias e agências reguladoras, que impõem diretrizes, estabelecem sanções e dispõem sobre métodos de fiscalização no âmbito econômico, social, financeiro, negocial e empresarial.

Insuficientes os mecanismos administrativos, pode-se dispor dos recursos do direito penal, o que, contudo, não significa dobrá-los à conveniência dos órgãos estatais de investigação, acusação e processamento criminais, os quais já dispõem de um aparato diversificado para obtenção de provas e para assegurar tanto o bom andamento do processo penal, quanto a prestação jurisdicional final.

É que, ao empregar o direito penal, não se pode negar partes dele. Isso mesmo: não se pode empregar mecanismos penais que restringem direitos do cidadão sem conferir a ele as garantias defensivas inerentes a essa área do direito. O direito penal e processual penal é uno, e carrega consigo prerrogativas, mas também deveres aos órgãos legiferantes e persecutores.

Logo, não há que se falar em um direito econômico penal, administrativizado. Trata-se de um direito penal econômico, que deve partir, sempre, da regra de garantia da presunção de inocência, que limita o ius puniendi estatal frente às regras do jogo democrático - seja no processo legislativo de criminalização, seja no processo penal. 
Nesse sentido, a regra de tratamento da presunção de inocência exige que o Estado trate o acusado como se inocente fosse, interferindo o mínimo possível em seus direitos, e conferindo-lhe um julgamento imparcial, equitativo e transparente, dispensados os meios necessários ao exercício de sua mais ampla defesa.

Nem a autoridade policial, ministerial ou jurisdicional pode tratar os acusados de crimes econômicos de maneira diferenciada, mais rígida, porque o procedimento investigatório e a ação penal não devem incutir punições a quem quer que seja, até que confirmada sua culpabilidade em sentença penal transitada em julgado.

Tem-se, então, que o grau de reprovabilidade da conduta criminosa do agente econômico não justifica a priorização de trâmite da investigação ou ação penal, nem a relativização dos requisitos para a denúncia, para os requerimentos de medidas cautelares, e para a execução provisória da pena.

Não podem haver atalhos ou facilitações por mera conveniência do poder público, eis que não cabe aos acusados "pagar a conta" pela morosidade do Judiciário. É tanto que, para reverter essa realidade, o CNJ vem elaborando relatórios anuais, e implementando um sistema de metas de produtividade para os magistrados brasileiros, enquanto o CPC adotou um sistema de precedentes judiciais.

Ademais, a regra de juízo da presunção de inocência veda a imposição à defesa de quaisquer deveres probatórios próprios da acusação, e exige que o juízo criminal não enxergue negativamente os acusados que não se dispuserem a colaborar na fase instrutória. 
Nessa fórmula, reside a própria legitimidade do direito penal e processual penal, porquanto conjunto indissolúvel de direitos do acusado, e deveres do acusador e julgador. Independentemente da capacidade econômica, tem-se como sujeito de direitos qualquer pessoa colocada sob o crivo penal, uma vez que todo indivíduo é o polo mais fraco quando o polo oposto é o Estado.

Optar pela flexibilização das garantias penais pode parecer um caminho mais fácil e sedutor para a tutela penal da ordem econômica. A alta comoção midiática em torno dos crimes econômicos inflamam a opinião pública à desumanização dos criminosos e ao punitivismo exacerbado, como bem pretende a tese do direito penal do inimigo.

Esse clamor social, ao chegar aos ouvidos dos operadores do direito, exige destes, em tese, uma escolha entre a presunção de inocência e a tutela efetiva da ordem econômica. Contudo, a tutela penal da ordem econômica somente pode ocorrer quando garantida a presunção de inocência, porque se trata de um pressuposto do direito penal e processual penal.

Fica assim reafirmada a incidência da presunção de inocência sobre a persecução dos crimes econômicos, em nome da manutenção das bases democráticas do Estado de Direito brasileiro. 


\section{Referências Bibliográficas}

ALEXANDRINO, Marcelo Alexandrino. PAULO, Vicente. Direito Administrativo Descomplicado. $18^{\mathrm{a}}$ ed. Revista e atualizada, Rio de Janeiro: Forense; São Paulo: Método, 2010. p. 187.

ALVARENGA, Darlan. Impacto da Lava Jato no PIB pode passar de $R \$$ 140 bilhões, diz estudo. G1, São Paulo, 11/08/2015. Disponível em: <http://g1.globo.com/economia/noticia/2015/08/impacto-da-lava-jato-nopib-pode-passar-de-r-140-bilhoes-diz-estudo.html>. Acesso em nov. 2018.

ANSELMO, Márcio Adriano. Com interpretação equivocada, direito ao silêncio virou jabuticaba no país. Disponível em: <https://www.conjur.com.br/2016-fev-23/academia-policia-interpretacaoequivocada-direito-silencio-virou-jabuticaba-pais>. Acesso em nov. 2018.

ARAUJO, Thiago C. M. de. O pensamento de Karl Marx e a Criminologia Crítica: Por uma Criminologia do Século XXI. Disponível em: <http://www.emerj.tjrj.jus.br/revistaemerj_online/edicoes/revista67/revista6 7_356.pdf>. Acesso em nov. 2018.

ARMANDO, Nicanor H. N. As normas penais em branco no âmbito do direito penal ambiental e a sua (in)constitucionalidade. Disponível em: <http://www.publicadireito.com.br/artigos/?cod=65f4086dbc18fa21>. Acesso em nov. 2018.

BACH, Marion; GUARAGNI, Fábio André. Norma penal em branco e outras técnicas de reenvio em direito penal. São Paulo: Almedina, 2014.

BADARÓ, Gustavo Henrique. Processo Penal - 5 ed. rev., atual e ampl. São Paulo: Editora Revista dos Tribunais, 2017. 
BANDEIRA, Leonardo Costa. Do direito constitucional de recorrer em liberdade. Belo Horizonte: Del Rey, 2003.

BARATTA, Alessandro. Criminologia Crítica e Crítica do Direito Penal. 6. ed, 4. reimp. Rio de Janeiro: Revan, 2017.

BAUMAN, Zygmunt. Estado de Crise. Rio de Janeiro: Editora Zahar, 2016.

BATISTA, Danilo. O princípio da vedação à autoincriminação no direito brasileiro: aplicações do nemo tenetur se detegere e seus desdobramentos no exercício da jurisdição penal. Disponível em: $<$ https://danilomocota.jusbrasil.com.br/artigos/257734573/o-principio-davedacao-a-autoincriminacao-no-direito-brasileiro-aplicacoes-do-nemotenetur-se-detegere-e-seus-desdobramentos-no-exercicio-da-jurisdicaopenal>. Acesso em nov. 2018.

BATISTA, Nilo. Apontamentos para uma história da legislação penal brasileira. Rio de Janeiro: Editora Revan, 2016.

BATISTA, Nilo. Introdução Crítica ao Direito Penal Brasileiro. 12 ed. Rio de Janeiro: Editora Revan, 2011. pp.

BATISTA, Vera Malaguti. Introdução Crítica à Criminologia Brasileira. Rio de Janeiro: Editora Revan, 2011.

BECCARIA, Cesare Bonesana. Dos delitos e das penas. Trad. Flório de Angelis. 2. Reimpr. São Paulo: EDIPRO, 1999. BENTO, Ricardo Alves. Presunção de inocência no Direito Processual. 
BENEVIDES, Marcelo. Direito penal econômico trata de quais crimes? Disponível em: <http://marcellobenevides.com/direito-penal-economicocrimes/>. Acesso em nov. 2018.

BETTI, Francisco de Assis. Lei n. 8.429/92 - dos crimes de corrupção e suas consequências. Revista CEJ, V. 4 n. 10 jan./abr. 2000. Disponível em: <http://www.cjf.jus.br/ojs2/index.php/revcej/article/viewArticle/253/523>.

BORBA, Maurício. A Inconstitucionalidade dos Crimes de Perigo Abstrato. Revista Jurídica da UNIFACS. apud LUZ, Renata C. D. A constitucionalidade dos crimes de perigo abstrato: a tipicidade do porte de arma de fogo desmuniciada com base na jurisprudência do STJ e do STF. Disponível em: <https://jus.com.br/artigos/20877/a-constitucionalidade-doscrimes-de-perigo-abstrato-a-tipicidade-do-porte-de-arma-de-fogodesmuniciada-com-base-na-jurisprudencia-do-stj-e-do-stf/6>. Acesso em nov. 2018.

BORGES, Bráulio. Como a Lava-Jato afetou o PIB? Novas evidências para $o$ debate. Disponível em: <https://blogdoibre.fgv.br/posts/como-lava-jatoafetou-o-pib-novas-evidencias-para-o-debate>. Acesso em nov. 2018.

BORGES, Bráulio. A diferença entre os efeitos da Lava-Jato no curto prazo e no médio e longo prazo. Disponível em: $<$ https://blogdoibre.fgv.br/posts/diferenca-entre-os-efeitos-da-lava-jato-nocurto-prazo-e-no-medio-e-longo-prazo>. Acesso em nov. 2018.

BOULANGER, Hervé. La criminalité économique en Europe. Paris: Presses Universitaires de France, 2002. 
BOTTINI, Pierpaolo Cruz. Princípio da precaução, direito penal e sociedade de risco. Revista Brasileira de Ciências Criminais, São Paulo, v. 61, p. 44-121, julho-agosto 2006, pp. 66-69.

CABETTE, Eduardo. A falácia do denominado "crime de perigo abstrato de perigosidade real”. Disponível em: $<$ https://eduardocabette.jusbrasil.com.br/artigos/151085894/a-falacia-dodenominado-crime-de-perigo-abstrato-de-perigosidade-real>. Acesso em nov. 2018.

CABETTE, Eduardo. Robert Merton e a criminalidade de colarinho branco: formulando uma hipótese de compatibilidade. Disponível em: <https://eduardocabette.jusbrasil.com.br/artigos/211599053/robert-mertone-a-criminalidade-de-colarinho-branco-formulando-uma-hipotese-decompatibilidade>. Acesso em nov. 2018.

CALLEGARI, André Luís. Imputação Objetiva. Lavagem de dinheiro e outros temas do Direito Penal. Porto Alegre: Livraria do Advogado, 2001. Vol. 1.

CAPEZ, Rodrigo. No processo penal não existe o poder geral de cautela. Disponível em: <https://www.conjur.com.br/2017-mar-06/rodrigo-capezprocesso-penal-nao-existe-poder-geral-cautela>. Acesso em nov. 2018.

CARNELUTTI, Francesco. 1957. As misérias do processo penal. Tradução de José Antonio Cardinalli. São Paulo: Editora Conan, 1995.

CARVALHO JÚNIOR, Almério Vieira de. Da norma penal em branco. In: Âmbito Jurídico, Rio Grande, XV, n. 97, fev 2012. Disponível em: < http://www.ambito- 
juridico.com.br/site/index.php?n_link=revista_artigos_leitura\&artigo_id=1 1110>. Acesso em nov 2018.

CASARA, Rubens. Uma ilustre desconhecida: a presunção de inocência. 2015. Disponível em:

<http://justificando.cartacapital.com.br/2015/01/17/uma-ilustredesconhecida-presuncao-de-inocencia/>.

CASTRO, Ana Paula Soares da Silva de. O Processo Penal é um direito constitucional aplicado?. Âmbito Jurídico, Rio Grande, XII, n. 66, jul 2009. Disponível em: <http://www.ambitojuridico.com.br/site/index.php?n_link=revista_artigos_leitura\&artigo_id=6 382>. Acesso em nov. 2018.

CHRISTIE, Nils. 1928- Uma razoável quantidade de crime. Tradução de André Nascimento. Rio de Janeiro: Renan, 2011.

COELHO, Fábio Ulhoa. Curso de Direito Comercial. Vol.1. 13a ed., São Paulo: Saraiva, 2009.

CUESTA, J. L.; CORDERO, Blanco Cordero. Resolutions of the Congresses of the International Association of Penal Law. International Review of Penal Law, vol. $\quad 86 . \quad$ Disponível em: $<$ http://www.penal.org/sites/default/files/RIDP86\%2012\%202015\%20EN.pdf>. Acesso em nov. 2018.

CUNHA, Rogério Sanches. Interrogatório: Informação sobre o direito ao silêncio $e$ nulidade. 2017. Disponível em: $<$ http://meusitejuridico.com.br/2017/06/29/interrogatorio-informacaosobre-o-direito-ao-silencio-e-nulidade/> 
DALLAGNOL, Deltan. A luta contra a corrupção. Rio de Janeiro: Primeira Pessoa, 2017.

DIAS NETO, Theodomiro. Segurança urbana: o modelo da nova prevenção. São Paulo: RT, 2005, p. 93.

DUCLERC, Elmir. Curso de Direito Processual Penal. apud LOPES JR., Aury. Direito Processual Penal - 13 ed. - São Paulo: Saraiva, 2016, p. 237.

DURKHEIM, Émile. Lições de Sociologia - a Moral, o Direito e o Estado, 1969 - Editora da Universidade de São Paulo, 2a edição.

Federação das Indústrias do Estado de São Paulo - FIESP. Relatório Corrupção: custos econômicos e propostas de combate, 2010. Disponível em: <http://www.fiesp.com.br/indices-pesquisas-e-publicacoes/relatoriocorrupcao-custos-economicos-e-propostas-de-combate/attachment/custoeconomico-da-corrupcao-final/>. Acesso em nov. 2018.

FERREIRA FILHO, Manoel Gonçalves. Curso de direito constitucional. 27 Ed. São Paulo: Saraiva, 2001, p. 20-21.

FONSECA, Gustavo Madureira. Modelo econômico na Constituição: análise, críticas e proposições sob uma ótica institucionalista. Disponível em: <http://www.publicadireito.com.br/artigos/?cod=0a09b1d63341c622>. Acesso em nov. 2018.

FRAGOSO, Heleno Cláudio. Direito penal econômico e direito penal dos negócios. Revista de Direito Penal e Criminologia, Rio de Janeiro, n. 33, p. 122-29, jan.-jun. 1982. 
FURMANN, Ivan. Marxismo e a crítica do Direito Penal. Disponível em: <http://www.egov.ufsc.br/portal/conteudo/marxismo-e-cr\%C3\%ADtica-dodireito-penal> . Acesso em nov. 2018.

GRAZINOLI GARRIDO, Rodrigo; LEAL RODRIGUES, Eduardo. $O$ Banco de Perfis Genéticos Brasileiro Três Anos após a Lei $n^{\circ} 12.654$. Rev. Bioética y Derecho, Barcelona, n. 35, p. 94-107, 2015. Disponível em: $<$ http://scielo.isciii.es/scielo.php?script=sci_arttext\&pid=S188658872015000300009\&lng=es\&nrm=iso>. Acesso em nov. 2018.

GRECO, Rogério. Curso de direito penal: Parte Geral. 17. ed. Rio de Janeiro: Impetus, 2015.

GUIMARÃES, Sérgio Chastinet Duarte. Tutela penal do consumo Abordagem dos aspectos penais do Código de Defesa do Consumidor e do Artigo $7^{\circ}$ da Lei ${ }^{\circ}$ 8.137, de 27.12.1990. Rio de Janeiro: Editora Revan, 2004.

HULSMAN, Louk L. La criminología crítica y el concepto del delito. In: RAMÍREZ, Juan Bustos. Prevencion y teoria de la pena. Editorial Jurídica ConoSur Ltda, Santiago de Chile, 1995.

JAKOBS, Gunther; MELIÁ, Manuel Cancio. Direito Penal do Inimigo: noções e críticas. Rio de Janeiro: Editora Livraria do Advogado, 2012.

JARDIM, Afrânio Silva. O princípio da indivisibilidade e a Ação Penal Pública Condicionada. Justitia, São Paulo, 51 (146), abr./jun., 1989. Disponível em <https://bdjur.stj.jus.br/jspui/bitstream/2011/22973/principio_indivisibilida de_acao_penal.pdf> 
JESCHECK, HansHeinrich. Tratado de derecho penal: parte general 4. ed. Granada: Comares, 1993.

KARAM, Maria Lúcia. Escritos sobre a Liberdade Volume 5: liberdade, presunção de inocência e direito à defesa. Rio de Janeiro: Editora Lumen Juris, 2009.

LAZERGES, Christine. La présomption d'innocence en Europe. Archives de politique criminelle, vol. 26, no. 1, 2004, pp. 125-138.

LOPES JR., Aury. Direito Processual Penal - 13 ed. - São Paulo: Saraiva, 2016.

LUPI, Mariana C. B. O depoimento dos casos de polícia criminal - O caso das Declarações do arguido. Disponível em: <https://repositorio.ucp.pt/bitstream/10400.14/15627/1/O\%20Depoimento \%20dos\%20Órgãos\%20de\%20Pol\%C3\%ADcia\%20Criminal\%20\%200\%20Caso\%20das\%20Declarações\%20do\%20Arguido.pdf>. Acesso em nov. 2018.

LUZ, Renata C. D. A constitucionalidade dos crimes de perigo abstrato: a tipicidade do porte de arma de fogo desmuniciada com base na jurisprudência do STJ e do STF. Disponível em: <https://jus.com.br/artigos/20877/a-constitucionalidade-dos-crimes-deperigo-abstrato-a-tipicidade-do-porte-de-arma-de-fogo-desmuniciada-combase-na-jurisprudencia-do-stj-e-do-stf/6> . Acesso em nov. 2018.

MAGAlHÃES, Leonardo C. O Pacto de São José da Costa Rica e o julgamento do RE-STF 466.343. Disponível em: $<$ https://jus.com.br/artigos/24454/o-pacto-de-sao-jose-da-costa-rica-e-ojulgamento-do-re-stf-466-343>. Acesso em nov. 2018. 
MARTINEZ, Ana Paula. Norma jurídica em matéria de crimes econômicos. Disponível em: <https://www.jota.info/especiais/norma-juridica-emmateria-de-crimes-economicos-e-analise-economica-direito-penal18072016>. Acesso em nov. 2018.

MARTINS NETO, Alfredo Pinheiro. Direito penal econômico como direito penal de perigo: a tutela da livre concorrência na sociedade de risco contemporânea, 2013. Dissertação (Mestrado em Direito UFPE).

MARTINS, Jomar. Presunção de inocência em concurso público se submete a interesse coletivo. Disponível em: <https://www.conjur.com.br/2016-mar08/presuncao-inocencia-concurso-submete-interesse-coletivo>. Acesso em nov. 2018.

MERTON, Robert K. Anomie, Anomia and Social Interaction: Contexts of Deviant Behavior. in: CLINARD, Marshall. Anomie and Deviant Behavior. New York: The Free Press, 213-242, 1964.

MERTON, Robert K., A Life of Learning. Charles Homer Haskins, 1994.

MERTON, Robert K. Opportunity Structure. in: ADLER, Freda; LAUFER, William. The Legacy of Anomie Theory. New Brunswick: Transaction Publishers, 3-78, 1995.

MESTIERI, João. Manual de Direito Penal. Rio de Janeiro: Editora Imprenta, 1999.

MESTIERI, João. Prisão preventiva em crime de colarinho branco deve ser exceção. Disponível em: <https://www.conjur.com.br/2016-mar- 
03/mestieri-preventiva-crime-colarinho-branco-excecao>. Acesso em nov. 2018.

MEYER-PFLUG, Samanta R; OLIVEIRA, Vitor E. T. O Brasil e o combate internacional à corrupção. Disponível em: <https://www12.senado.leg.br/ril/edicoes/46/181/ril_v46_n181_p187.pdf>. Acesso em nov. 2018.

MOREIRA, Rômulo de Andrade. Lei que trata processo administrativo do Banco Central do Brasil é restritiva de direito. Disponível em: <http://www.justificando.com/2017/11/17/lei-que-trata-processoadministrativo-do-banco-central-do-brasil-e-restritiva-de-direito/>. Acesso em nov. 2018.

NUCCI, Guilherme de Souza. Manual de processo penal e execução penal: 14 ed. rev., atual. e ampl. - Rio de Janeiro: Forense, 2017.

NUCCI, Guilherme de Souza. Leis penais e processuais penais comentadas: 2 ed. rev., atual. e ampl. - São Paulo: Editora Revista dos Tribunais, 2007a.

NUSDEO, Fábio. Curso de Economia: introdução ao direito econômico. São Paulo: Editora RT, 1997.

OLIVEIRA, Eugênio Pacelli de. Curso de Processo Penal - 20. ed. rev., atual. São Paulo: Atlas, 2016.

OLIVEIRA, Monique A. B. de. O direito de recorrer em liberdade do réu e a inconstitucionalidade da execução provisória da sentença penal condenatória proferida em segundo grau de jurisdição. Rio de Janeiro/RJ, 2016. 117 f. Monografia, Faculdade de Direito da Universidade Federal do Rio de Janeiro. 
OVINSKI, Mônica. O Estado e o Indivíduo: o conflito entre punir e libertar - história da presunção de inocência no Brasil (1948 - 2000). 2001. Dissertação (Mestrado em Direito). Centro de Ciências Jurídicas, Universidade Federal de Santa Catarina, Santa Catarina.

PASSETTI, Edson; HULSMAN, Louk; KARAM, Maria Lúcia; BATISTA, Nilo; OLIVEIRA, Salete; RODRIGUES, Thiago; BATISTA, Vera Malaguti. Curso livre de abolicionismo penal. 2 ed. Rio de Janeiro: Revan, 2012.

PENNINGTON, Kenneth. Innocent Until Proven Guilty: The Origins of a Legal Maxim, 63 JURIST: STUD. CHURCH L. \& MINISTRY 106, 2003.

PEREIRA, Caio Mário da Silva. Instituições de direito civil - 27 ed. Rio de Janeiro: Forense, 2014.

PEREIRA, Pedro H. S.; FONSECA, Michelle S. de O. Considerações acerca dos maus antecedentes criminais. Disponível em: <http://www.ambitojuridico.com.br/site/index.php?n_link=revista_artigos_leitura\&artigo_id=7 892>. Acesso em nov. 2018.

PÉREZ, Carlos M. B. Os crimes de perigo no Direito Penal Econômico e Empresarial. Disponível em: <http://www.revistaliberdades.org.br/_upload/pdf/17/artigo2.pdf>. Acesso em nov. 2018.

PILONI, Caroline de Paula Oliveira. Princípio da não-culpabilidade: aspectos teóricos e práticos. Revista Jus Navigandi, ISSN 1518-4862, Teresina, 2013 Disponível em: <https://jus.com.br/artigos/25467>. Acesso em: 30 out. 2018. 
PIMENTA, Eduardo Goulart; LANA, Henrique A. R. P. Análise econômica do direito e sua relação com o direito civil brasileiro. Disponível em: <https://www.direito.ufmg.br/revista/index.php/revista/article/viewFile/126 /118>. Acesso em nov. 2018.

PITOMBO, Antônio Sérgio A. de Moraes. A lei de lavagem de dinheiro. São Paulo: Gazeta Mercantil - p. A-11, 2007. Disponível em: <http://www.apitombo.com.br/images/userfiles/file/2_5_16.pdf>. Acesso em nov. 2018.

PITOMBO, Antonio Sérgio A. de Moraes. Juiz é fiscal dos atos do MP, e não defensor deles. Revista Consultor Jurídico, 29 dez. 2009. Disponível em: <http://www.conjur.com.br/2009-dez-29/juiz-criminal-fiscalatosacusatorios-nao-defensor-deles>. Acesso em nov. 2018.

PITOMBO, Antonio Sérgio A. de Moraes. Lavagem de dinheiro. São Paulo: Revista dos Tribunais, 2003.

PITOMBO, Antônio Sérgio A. de Moraes. Organização Criminosa: nova perspectiva do tipo legal. São Paulo: Revista dos Tribunais, 2009.

PITOMBO, Cleunice A. Valentim Bastos. Da busca e apreensão no processo penal - $2^{\mathrm{a}}$ ed. São Paulo: Revista dos Tribunais, 2004.

PRADO, Luiz Regis. Direito penal econômico - 7 ed. rev. e atual. - São Paulo: Revista dos Tribunais, 2016.

RIBEIRO, Ivan M. O que é, afinal, condução coercitiva? Disponível em: <https://canalcienciascriminais.jusbrasil.com.br/artigos/311252199/o-quee-afinal-a-conducao-coercitiva>. Acesso em nov. 2018. 
ROCHA, Thiago dos S. Espiritualização do bem jurídico e direito penal de segunda velocidade. Disponível em: $<$ https://jus.com.br/artigos/53096/espiritualizacao-do-bem-juridico-edireito-penal-de-segunda-velocidade>. Acesso em nov. 2018.

ROESLER, Átila da Rold. Aspectos criminais da Lei de Licitações. Disponível em: <https://jus.com.br/artigos/5635/aspectos-criminais-da-leide-licitacoes>. Acesso em nov. 2018.

ROMEIRO NETO, João. O Direito penal militar nos casos concretos. Rio de Janeiro: José Konfino, 1966.

ROMERO, Diego. Reflexões sobre os Crimes de Perigo Abstrato. Revista IOB Direito Penal e Processual Penal, São Paulo, v. 39, p. 43-62, ago.-set. 2006.

SALDANHA, Renata T. O princípio da vedação à autoincriminação, a mentira e seus reflexos processuais penais. Disponível em: <http://erevista.unioeste.br/index.php/csaemrevista/article/viewFile/17518/11673>. Acesso em nov. 2018.

SANTOS, Juarez Cirino dos. Direito penal: parte geral. 3. ed. Curitiba: ICPC; Lumen Júris, 2008.

SANTOS, Juliana Pinheiro. Questão conceitual: Crimes de colarinhobranco ou crimes econômicos? Disponível em: <http://www.ambitojuridico.com.br/site/index.php?n_link=revista_artigos_leitura\&artigo_id=9 179>. 
SCHILlING, Flávia. Corrupção: ilegalidade intolerável. Comissões parlamentares de inquérito e a luta contra a corrupção no Brasil (1980-1992). São Paulo: IBCCrim, 1999.

SCHREIBER, Simone. A publicidade opressiva dos julgamentos criminais. 2009. Disponível em http://www.cartaforense.com.br/conteudo/artigos/apublicidade-opressiva-dos-julgamentos-criminais/4643.

SILVA, Douglas R. Normas penais em branco são inconstitucionais? Canal Ciências Criminais. Disponível em: $<$ https://canalcienciascriminais.com.br/normas-penais-em-branco/>. Acesso em nov. 2018.

SILVA, Grazielle E. Provas no processo penal. Disponível em: $<$ https://www.direitonet.com.br/artigos/exibir/10779/Provas-no-ProcessoPenal>. Acesso em nov. 2018.

SILVA, Ivan Carlos da. $O$ direito penal do inimigo. Disponível em: <http://unisinos.br/blogs/ndh/2013/07/29/o-direito-penal-do-inimigo/>. Acesso em nov. 2018.

SILVA SÁNCHEZ, Jésus-Maria. A expansão do direito penal: aspectos da política criminal nas sociedades pós-industriais. Tradução de Luiz Otavio de Oliveira Rocha. 3. ed. rev. e. atual. São Paulo: Editora Revista dos Tribunais, 2013.

SILVA, Lucas S. G. A (in)constitucionalidade do crime de direção sob a influência de álcool. Salvador/BA, 2015. 71 f. Monografia, Faculdade Baiana de Direito. 
SILVEIRA, Renato de Mello Jorge. Direito penal econômico como direito penal de perigo. São Paulo: Editora Revista dos Tribunais, 2006.

SUTHERLAND, Edwin H. Crime de colarinho branco: versão sem cortes; tradução: Clécio Lemos. Rio de Janeiro: Revan, 2015, $1^{\text {a }}$ reimpressão, setembro de 2016.

TALON, Evinis. Provas invasivas e não invasivas no processo penal. 2018. Disponível em: <http://evinistalon.com/provas-invasivas-e-nao-invasivasno-processo-penal/>

THOMPSON, Augusto. Quem são os criminosos? O crime e o criminoso: entes políticos. Rio de Janeiro: Editora Lumen Juris, 2007.

WELZEL, Hans. Das DeutscheStrafrecht: De Gruyer Lehrbruch.11. ed. Berlín, 1969.

ZAFFARONI, Eugenio Raúl. Crime Organizado: uma categorização frustrada. Discursos Sediciosos - Crime, direito e sociedade. Rio de Janeiro: Instituto Carioca de Criminologia, vol. 1, 1996.

ZAFFARONI, Eugenio Raúl; BATISTA, Nilo; ALAGIA, Alejandro; SLOKAR, Alejandro, Direito Penal Brasileiro: primeiro volume. Rio de Janeiro: Revan, 2003, $4^{\text {a }}$ edição, 2011. $2^{a}$ reimpressão, 2015.

ZAFFARONI, Eugenio Raúl; BATISTA, Nilo; ALAGIA, Alejandro; SLOKAR, Alejandro, Direito Penal Brasileiro: segundo volume, parte I. Rio de Janeiro: Revan, 2003. 
ZACKESCKI, Cristina Maria; GOMES, Patrick Mariano. O que é ordem pública no sistema de justiça criminal brasileiro? Revista Brasileira de segurança pública, São Paulo, v. 10, n. 1, pp. 108-126, fev./mar. 2016.

ZAFFARONI, Eugenio Raúl. Em busca das penas perdidas: a perda da legitimidade do sistema penal. Tradução Vania Romano Pedrosa, Amir Lopez da Conceição. 5a ed. Rio de Janeiro: Revan, 2001.

ZAFFARONI, Eugenio Raúl. O Inimigo no Direito Penal. Rio de Janeiro: Revan, 2007.

<https://www.cidh.oas.org/basicos/portugues/c.convencao_americana.htm> $<$ http://www.stf.jus.br/portal/cms/verNoticiaDetalhe.asp?idConteudo=1028 69>

<https://www.apadep.org.br/revista/carreira-enfrenta-excesso-de-trabalhoe-falta-de-estrutura/>

<http://www.stj.jus.br/sites/STJ/default/pt_BR/Comunicação/noticias/Not\% C3\%ADcias/Violação-do-direito-ao-silêncio-torna-i1\%C3\%ADcitodepoimento-de-testemunha>

<https://www.conjur.com.br/dl/trf-confirma-sentenca-negou-apelacao.pdf > <https://www.conjur.com.br/2016-abr-10/stj-reafirma-embriaguez-volantenao-exige-perigo-concreto>

<http://wiki.ued.ipleiria.pt/wikiMarketing/index.php/Noções_de_finanças> 
<http://www.cnj.jus.br/noticias/cnj/87448-tribunais-tem-60-dias-pararegularizar-audiencias-de-custodia>

<http://www.cnj.jus.br/noticias/cnj/85361-estatisticas-mostram-evolucaodo-combate-a-morosidade-na-justica>

<http://www.stf.jus.br/portal/cms/verNoticiaDetalhe.asp?idConteudo=2993 85> 